\title{
LIVRE DOCENCIA
}

\section{A trajetória do Turismo Rural no Estado de São Paulo: um segmento turístico em desenvolvimento}

\author{
KARINA TOLEDO SOLHA
}

Tese apresentada como requisito parcial para ao Concurso de Habilitação à Livre-Docência, junto ao Departamento de Relações Públicas, Propaganda e Turismo, da Escola de Comunicações e Artes, Universidade de São Paulo. 
Autorizo a reprodução e divulgação total ou parcial deste trabalho, por qualquer meio convencional ou eletrônico, para fins de estudo e pesquisa, desde que citada a fonte.

Catalogação na Publicação Serviço de Biblioteca e Documentação

Escola de Comunicações e Artes da Universidade de São Paulo

Dados fornecidos pelo(a) autor(a)

\section{SOLHA, KARINA TOLEDO SOLHA}

A trajetória do turismo rural em São Paulo:: um segmento turístico em desenvolvimento / KARINA TOLEDO SOLHA SOLHA. -- São Paulo: K. T. S. SOLHA, 2016.

$150 \mathrm{p}$.

Livre-docência - Escola de Comunicações e Artes / Universidade de São Paulo.

Bibliografia

1. Turismo rural 2. Empreendimentos 3. Empreendedores 4. Configuração do campo 5. Estado de São Paulo I. Título.

CDD 21.ed. - 910 


\section{UNIVERSIDADE DE SÃO PAULO}

ESCOLA DE COMUNICAÇÕES E ARTES

\section{A trajetória do Turismo Rural no Estado de São Paulo: um segmento turístico em desenvolvimento}

Karina Toledo Solha

Tese apresentada para o concurso de Livre Docente na Escola de Comunicações e Artes - USP

Banca Examinadora

Presidente da Banca 
A família,

que compartilha as alegrias e as dificuldades destas empreitadas. 


\section{Agradecimentos}

Muitas vezes dizemos que o trabalho intelectual é solitário. Mas minha experiência me mostrou que não. Escrever e finalizar o documento é apenas uma parte da tarefa, que começou muito tempo atrás.

A formação de um pesquisador demanda sim uma grande dedicação pessoal, mas ela só avança e amadurece com a experiência e com a orientação de professores comprometidos e dedicados.

É um privilégio ter a oportunidade de conviver com tantos docentes e pesquisadores diferentes e aprender com eles todo o tempo. Com uns a gente encontra inspiração, com outros se aprende a ser cuidadoso e rigoroso no trabalho que desenvolve.

Ainda tem os amigos que nos estimulam e nos apoiam tanto em atitudes e quanto em palavras. E em saborosas conversas nos iluminam e nos ajudam a ver a realidade por diferentes prismas.

Tem os alunos jovens ou maduros, parceiros em muitos momentos e que nos ajudam a manter nossa curiosidade com o mundo nos apresentando novos desafios cotidianamente.

Tem os parceiros além da universidade que comungam dos mesmos interesses e princípios, e com os quais vamos tentando construir um mundo melhor.

Tem aqueles que nunca nos viram, mas foram extremamente gentis em nos disponibilizar informação, dados e sugestões.

Tem aqueles que convivem conosco cotidianamente e que fazem a Universidade funcionar.

Tem a família que acompanha o processo, por vezes não compreendendo o motivo de tanta dedicação.

Impossível agradecer nominalmente sem esquecer ninguém. Então compartilho o sentimento desta canção do Almir. Obrigada! 
Galo cantou

Madrugada na Campina

Manhã menina

Tá na flor do meu jardim

Hoje é domingo

Me desculpe eu tô sem pressa

Nem preciso de conversa

Não há nada prá cumprir

Passar o dia

Ouvindo o som de uma viola

Eu quero que o mundo agora

Se mostre pros bem-te-vi

Mando daqui das bandas do rural

lembranças

Vibrações da nova bora

Prá você que não tá aqui

Amanbecer

é uma lição do universo

Que nos ensina

Que é preciso renascer

O novo amanhece

O novo amanhece

Já tem rolinba

Lá no terreiro varrido

E o orvalho brilha

Como pétalas ao sol

Tem uma sombra

Que caminha pras montanhas

Se espelhando feito alma

Por dentro do matagal

E quanto mais

A luz vai invadindo a terra

O que a noite não revela

$O$ dia mostra prá mim

A rádio agora

Tá tocando Rancho Fundo

Somos só eu e mundo

E tudo começa aqui

Amanbecer

é uma lição do universo

Que nos ensina

Que é preciso renascer

O novo amanhece

O novo amanhece

(Raizes, Almir Sater) 
"Não sou eu quem me navega, Quem me navega é o mar É ele que me carrega Como nem fosse levar..."

Timoneiro, Paulinho Da Viola e Hermínio Bello De Carvalho 


\section{Resumo}

O turismo rural se origina como uma estratégia para estimular o desenvolvimento em áreas rurais em declínio, refletindo e influenciando a dinâmica do universo rural, com presença cada vez mais expressiva nas pequenas e médias propriedades agrícolas. A sua trajetória de expansão está intrinsecamente associada às transformações sociais contemporâneas em que as relações entre urbano e rural são rediscutidas e revistas cotidianamente. Diante deste contexto, propôs-se investigar a configuração do turismo rural no Estado de São Paulo, buscando identificar e analisar os elementos que o conformam e contribuíram para determinar sua trajetória. Para tanto, esta pesquisa apoiou-se em uma revisão documental e bibliográfica, apoiada em dois estudos. O primeiro, um estudo do estado da arte com base em dissertações e teses acadêmicas sobre turismo rural, e o segundo um estudo do tipo levantamento apoiado em dados secundários sobre os empreendedores de turismo rural. Constatou-se que a realidade paulista tem sido timidamente examinada pelos investigadores, que a questão do desenvolvimento como principal motivador de seus estudos. Destaca-se a capacidade de superação dos empreendedores, sendo que muitos estão na fase de consolidação de suas atividades, mesmo contando com um apoio acanhado e pouco articulado do poder público. Verificou-se ainda, uma grande fragilidade nas informações disponíveis que não abarcam a dimensão e a complexidade do segmento. Diante de um cenário de novos desafios, seria oportuno investir no fortalecimento e aprimoramento da atuação dos empreendedores.

Palavras-chave: Turismo rural. Empreendimentos. Empreendedores. Configuração do campo. Estado de São Paulo. 


\section{Abstract}

Rural tourism originated as a strategy to stimulate development in declining rural areas, reflecting and influencing the dynamics of the agrarian milieu, having an ever growing presence in small and medium-sized farming properties. Its course of expansion is intrinsecaly associated with the contemporary social trasnformations in which the relationships between urban and rural are reviewed and rediscussed on a daily basis. In light of this context, an investigation of the rural tourism setting in the State of São Paulo has been proposed, seeking to identify and analyse the elements that compose it and which contributed to determine its course. Therefore, this research has based itself on document and bibliographic reviews, supported by two studies. The former, a study of the state of the art based on dissertations and academical theses on rural tourism, whereas the latter, a stocktaking study based on secondary data on rural tourism entrepreneurs. The study found that the reality in the State of São Paulo has been coyly assessed by researchers, whose main motivator for their studies is the development matters. The overcoming ability of the entrepreneurs has been highlighted, with many taking steps to consolidate their activities, even though being minimally and inarticulately backed by public authorities. The available information, which do not encompass the scope and complexity of the niche, has proved quite weak. In light of a scenario with new challenges, investing in the strengthening and improvement of the entrepreneurs performance would be advisable.

Keywords: Rural tourism. Enterprises. Entrepreneurs. Agriculture settings. State of São Paulo. 


\section{Lista de Siglas}

ABRATURR

ABTR

ANCL

APRECESP

ARCCO

ASTUR

ATRCF

ATURP

CAPES

CATI

CBTR

CITURDES

ECA

ESALQ

FAESP

FAPESP

FEALQ

FFLCH

IBGE

IBICT

IDESTUR

IICA

LEADER

OECD

OMT

PETAR

PMDRS
Associação Brasileira de Turismo Rural

Associação Brasileira de Turismo Rural

Associação Natureza Café com Leite

Associação das Prefeituras Estâncias do Estado de São Paulo

Associação Roteiros Caminhos da Corte, na região do Vale Histórico

do Estado de São Paulo.

Associação do Turismo Rural do Médio Tietê

Associação de Turismo Rural do Circuito das Frutas

Associação de Turismo Rural de Ribeirão Preto e Região

Coordenadoria de Aperfeiçoamento do Ensino Superior

Coordenadoria de Assistência Técnica Integral do Estado de São Paulo

Congresso Brasileiro de Turismo Rural

Congresso Internacional sobre Turismo Rural e Desenvolvimento Sustentável

Escola de Comunicações e Artes

Escola Superior de Agronomia Luiz de Queiroz, da Universidade de São Paulo

Federação da Agricultura e Pecuária do Estado de São Paulo

Fundação de Apoio à Pesquisa no Estado de São Paulo

Fundação de Estudos Agrários Luiz de Queiroz

Faculdade de Filosofia, Letras e Ciências Humanas

Instituto Brasileiro de Geografia e Estatística

Instituto Brasileiro de Informação, Ciência e Tecnologia

Instituto de Desenvolvimento do Turismo Rural

Instituto Interamericano de Cooperación para la Agricultura

Liaison entre actions de développement rural

Organização para Cooperação e Desenvolvimento Econômico

OrganizaçãoMundial do Turismo

Parque Estadual Turístico do Alto Ribeira

Planos Municipais de Desenvolvimento RuralSustentável 
PROCAM

SciElo

SEBRAE

SENAC

SENAR

UAM

UFSCAR

UFSM

UNESP

UNICAMP

UNIVAP

UPAs

UPR

USP
Programa de Pós Graduação em Ciência Ambiental

Scientific Electronic Library Online

Serviço Nacional de Apoio ao Pequeno Empreendedor

Serviço Nacional de Aprendizagem Comercial

Serviço Nacional de Aprendizagem Rural

Universidade Anhembi Morumbi

Universidade Estadual de Campinas

Universidade Federal de Santa Maria

Universidade Paulista

Universidade Federal de São Carlos

Universidade do Vale do Paraíba

Unidades Produtivas Agropecuárias

Unidades Produtivas Rurais

Universidadede São Paulo 


\section{Lista de Tabelas}

Tabela 1 - Efeitos do Turismo Rural 33

Tabela 2 - Perfil empresarial dos empreendimentos de turismo rural brasileiros 40

Tabela 3 - Produção científica segundo objetivos da pesquisa 70

Tabela 4 - Atividades Econômicas Rurais não Agropecuárias, Estado de São Paulo $2007 / 2008$

Tabela 5 - Empreendimentos Rurais segundo região administrativa 109

Tabela 6 - Empreendimentos de turismo rural no Estado de São Paulo segundo atrativos turísticos

Tabela 7 - Empreendimentos de turismo rural no Estado de São Paulo segundo tipos de atividades desenvolvidas - 2014

Tabela 8 - Empreendimentos de turismo rural no Estado de São Paulo segundo tempo de atuação na atividade 


\section{Lista de Figuras}

Figura 1 - Evolução dos domicílios rurais de uso ocasional 2000-2010

Figura 2 - Produção científica brasileira por período e por área objeto de estudo ................ 48

Figura 3 - Linha do Tempo - surgimento do Turismo Rural

Figura 4 - Produção científica sobre turismo rural no estado de São Paulo, segundo nível de

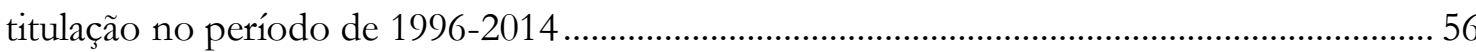

Figura 5 - Linha do Tempo das políticas públicas de turismo rural no Brasil ........................ 57

Figura 6 - Produção científica sobre turismo rural no estado de São Paulo segundo instituição produtora. 58

Figura 7 - Distribuição espacial dos estudos sobre turismo rural no estado de São Paulo.. 60

Figura 8 - Objeto dos estudos sobre turismo rural no estado de São Paulo..... 61

Figura 9 - Mapa da quantidade de propriedades no Pólo Turístico do Circuito das Frutas 62 Figura 10 - Empreendimentos de turismo rural no Estado de São Paulo................................. 63

Figura 11 - Municípios com atividade de turismo rural .65

Figura 12 - Ocupação dos respondentes pelos empreendimentos rurais do estado de São Paulo 104

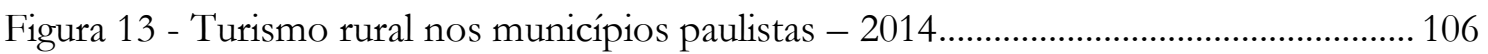

Figura 14 - Empreendimentos de turismo rural nos municípios paulistas - 2014 ................ 107

Figura 15 - Circuitos e Roteiros Turísticos do Estado de São Paulo 110

Figura 16 - Empreendimentos inseridos nos Circuitos e Roteiros do Estado de São Paulo

Figura 17 - Empreendimentos de turismo rural segundo funcionamento ao público - ano

Figura 18 - Empreendimentos formalizados junto a órgãos públicos

Figura 19 - Quantidade de trabalhadores e participação dos familiares nos

empreendimentos de turismo rural no Estado de São Paulo

Figura 20 - Auxílio dos familiares nos empreendimentos de turismo rural no Estado de São

Paulo

Figura 21 - Empreendimento segundo situação dos trabalhadores

Figura 22 - Práticas Agrícolas no Empreendimento de turismo rural 124

Figura 23 - Orgiem dos visitantes do Empreendimento de Turismo rural no Estado de São

Paulo. 126

Figura 24 - Empreendimentos de Turismo rural do Estado de São Paulo segundo as estratégias de divulgação 


\section{Sumário}

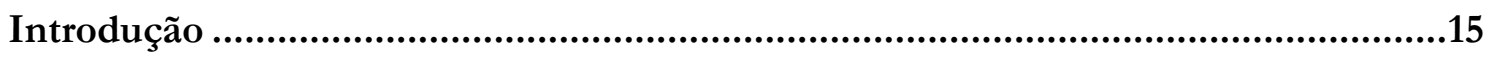

1 Turismo Rural: Evolução dos Estudos e Interfaces com o Mercado .................... 22

1.1 Evolução dos estudos na relação entre turismo e ruralidade............................................ 23

1.2 Percepção de um Universo em transformação ................................................................... 29

1.3 Dinâmica e organização na ótica do mercado .................................................................... 36

2 Estudos do Turismo Rural na Realidade Paulista ........................................... 46

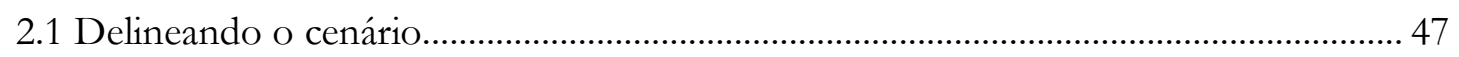

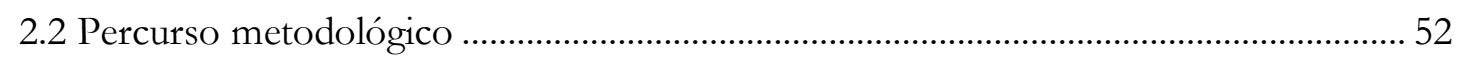

2.3 Configuração da Produção Acadêmica .............................................................................. 55

2.4 Turismo Rural Paulista no Cenário Brasileiro.................................................................. 73

3 Turismo Rural como Negócio: Empreendimentos em São Paulo ....................... 93

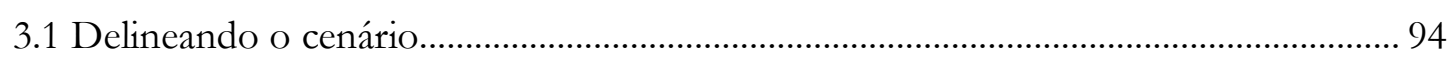

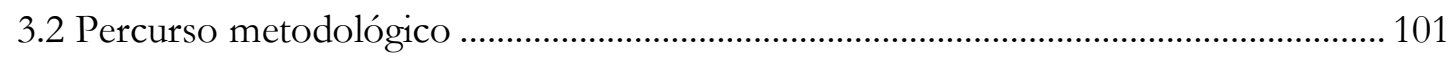

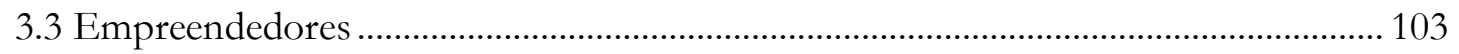

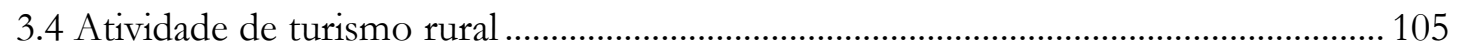

3.5 Estrutura do negócio .................................................................................................. 119

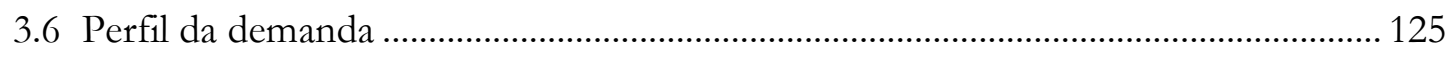

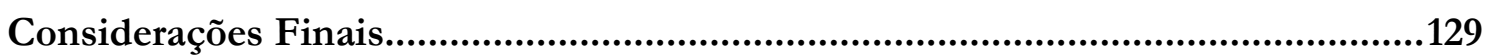

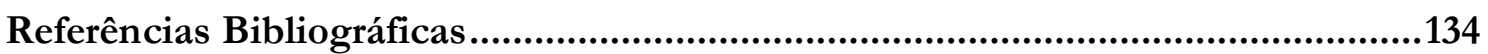

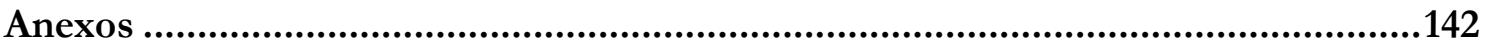




\section{Introdução}


Se por exemplo, o leitor empreende uma viagem maritima numa jangada com um papagaio e cinco companheiros, mais cedo ou mais tarde, inevitavelmente, acordará numa manbã em pleno mar, talvez. um pouco mais descansado que de costume, $e$ começará a matutar no caso.

(Heyerdahl, 1987)

Sempre gostei de histórias de viagem, especialmente aquela contada por Thor Heyerdahl em “A expedição Kon-tiki”. A possibilidade de acompanhar o protagonista em todos os momentos de sua trajetória, desde os preparativos e a ansiedade pela jornada, aos inúmeros reveses e superações que ocorrem ao longo do trajeto, faz aflorar muitos sentimentos, por vezes contraditórios. E ao final, compartilhar com o protagonista a alegria, não somente por ter alcançado os resultados desejados, mas pela profunda transformação pessoal que a experiência provocou.

A construção desta tese de Livre-Docência é a minha mais recente viagem e começou em 2000, quando um programa de televisão de Minas Gerais, convidou-me para conversar sobre turismo rural. Tema que ainda não fazia parte de meus estudos, mas que se inseria delicadamente no meu universo profissional. Mas só comecei a me dedicar a ele seriamente em 2010, quando desenvolvi uma investigação sobre como os pesquisadores brasileiros estavam tratando do assunto. $\mathrm{O}$ fator motivador estava relacionado às minhas inquietações com a produção científica em turismo e sua capacidade de gerar e transferir conhecimento. E ao longo do processo descobri um objeto de estudo instigante pela sua complexidade e atualidade.

Dizem que conhecimento gera conhecimento, porque ao final de cada estudo nos deparamos com mais e mais questionamentos. De fato, ao finalizar o relatório de pesquisa em 2011, 
ainda estava inquieta e insatisfeita. A investigação apontara para muitas lacunas e haviam algumas poucas sinalizações de resposta para questões importantes. Mesmo assim, apresentei os resultados da pesquisa em artigos científicos e procurei garantir que a discussão tivesse a maior visibilidade possível, atendendo a inúmeros convites para palestras junto aos profissionais e gestores públicos que buscavam informações sobre o tema. E a cada encontro, cada debate aumentava meu incômodo, pois não dispunha ainda de informações que poderiam contribuir para qualificar as ações técnicas, políticas ou mesmo operacionais no turismo rural.

Entre outras coisas, faltavam os números, seja acerca dos empreendimentos, seja mesmo da demanda de turistas para produtos ou serviços com estas características. Esta é uma das questões fundamentais a ser respondida ao iniciar qualquer processo de planejamento turístico, pois ao compreender a realidade tem-se os elementos necessários para então propor qualquer estratégia para sua transformação.

A necessidade de entender o segmento e sua dinâmica de gestão e de operação dos negócios, pode ser percebida nos vários estudos sobre perfil dos empreendimentos de turismo rural, elaborados por entidades que percebem o potencial e a relevância do segmento. Contudo ainda com resultados pouco confiáveis.

Afinal qual é o obstáculo? Com tantos pesquisadores dedicados a refletir sobre as diversas problemáticas, com os congressos e encontros científicos, técnicos e comerciais ocorrendo sistematicamente por todo o país, com a preocupação do poder público federal em implementar uma política pública adequada para o segmento, porque ainda não temos dados consistentes?

No início, esta situação poderia ser compreendida como uma decorrência da dificuldade de estabelecer um conceito operacional que pudesse apoiar as políticas públicas para a área. Seguramente, este foi um grande avanço, pois permitiu que fossem elaboradas diretrizes e 
estratégias públicas para apoiar seu desenvolvimento. Todavia a ausência de estudos mapeando a realidade dos empreendimentos de turismo rural ainda permanece, por um lado pode ser decorrente da natural dificuldade de assimilação de novos paradigmas apontada por Tulik (2010), ou porque o conhecimento disponível ainda não seja suficiente.

Um dos principais entraves para a expansão dos empreendimentos de turismo rural estava relacionado à legislação, em especial a aspectos da tributação sobre os serviços turísticos prestados por unidades produtivas rurais. Por isso muitos empreendedores preferiram ficar na informalidade. E, até então, sempre que se propunham estudos para mapear e caracterizar estes empreendimentos, os resultados eram pífios, poucos precisos e frágeis. Mas será que a recente aprovação da lei vai provocar o interesse na formalização? Será que com isso teremos os elementos necessários para mensurar a expressão do turismo rural como negócio? Como isto é muito recente, deveremos aguardar o tempo para observar novamente.

Pode ser que isso simplifique a identificação daqueles empreendedores que considerem que sua formalização gerará algumas facilidades na operação do negócio. Contudo ainda não apresenta elementos suficientes para apoiar uma análise aprofundada sobre dinâmica, estrutura, impactos destes micro e pequenos empreendimentos. Trata-se de observar e entender "um mundo de tradições rurais em trânsito, imerso num dramático percurso de perdas e de novas mudanças" (Pellicciotta $\left.{ }^{1}, 2016\right)$, no qual o turismo se insere como uma estratégia de salvaguarda.

Assim temos ao mesmo tempo que acompanhar uma alteração nos paradigmas do que se entende como rural, já expressa oficialmente em documentos do IBGE, que vem sendo discutida por vários investigadores dedicados a temática, e entender como se estrutura sua interface com o turismo, entendido como uma das atividades que podem existir num universo cada vez mais plural.

\footnotetext{
${ }^{1}$ M.Pellicciotta (comunicação pessoal, 2016)
} 
Certamente um desafio! Tanto para nossa realidade quanto para a europeia, fato salientado por Lane (2014, p. 19) ao afirmar que "o turismo rural assustou alguns profissionais por causa de sua fragmentação, complexidade, confiança em pluriatividade fora do turismo, e, algumas vezes por causa de seu comportamento percebido como irracional”. Alguma semelhança?

Isto oferece uma pista para compreender porque nas discussões científicas, técnicas ou comerciais "o turismo rural é percebido como um segmento descolado do universo mais amplo do turismo, quase que exclusivamente compreendido pela óptica das propriedades rurais, por si mesmas" (Solha \& Rejowski 2013, p. 119). Emerge assim um cenário de intrincadas relações que não podem ser deslindadas por um ou outro campo do conhecimento, pois precisa de uma abordagem interdisciplinar.

E parece que isto já está a caminho.... Este ano o IBGE realiza novamente o Censo Agropecuário e havia uma proposta de inserção de um questionamento acerca da presença de atividades de turismo rural nas unidades produtivas rurais do país. Pode-se entender como uma sinalização da relevância que o lazer e turismo vem adquirindo como atividade nãoagrícola. E certamente despertará o interesse de pesquisadores de outras áreas do conhecimento para este intrigante objeto de estudo.

Diante deste contexto, parece ser premente avançar na busca de subsídios que permitam identificar e analisar os elementos que configuram o turismo rural e contribuem para determinar sua trajetória no país. Assim, propôs-se contribuir com esta construção investigando o turismo rural no Estado de São Paulo, o qual se destaca no cenário nacional como principal emissor e receptor de turistas do país. A isto se agrega uma atuação reconhecida e permanente dos profissionais, pesquisadores e empreendedores do turismo rural do Estado, refletida pela organização de encontros acadêmicos, técnicos e comerciais, e pela capacidade de mobilização e articulação representando o segmento nos diferentes espaços de discussão política e profissional nacionais. 
Face a essas considerações, este estudo objetiva, primariamente, analisar a configuração do turismo rural paulista, que se desdobra, secundariamente em: a) compreender como o rural se entrelaça com a oferta da experiência de turismo rural; b) reconhecer o papel do conhecimento científico na compreensão do segmento do turismo rural; c) verificar a dinâmica e a estrutura da operação dos negócios desse segmento. Para tanto, desenvolvi duas pesquisas, sendo uma de caráter documental na forma de estudo do estado da arte (Ferreira, 2002) e outra na forma de levantamento (Dencker, 2007) com base em dados secundários. As respectivas propostas metodológicas são explicitadas detalhadamente nos capítulos 2 e 3 , uma vez que as estratégias adotadas diferem nesses dois momentos.

Optei por não formular hipóteses, face ao conhecimento científico sobre turismo rural, especialmente no Brasil e, mais precisamente, no Estado de São Paulo, não estar sistematizado o que indica a sua fragmentação e dispersão. Assim, paralelamente à minha participação ativa e aproximação efetiva em eventos e com entidades representativas da área, respectivamente, o estudo foi sendo delineado a partir da seleção, consulta e análise de bibliografia, documentos e estudos sobre o assunto. Nesse período, de 2009 a 2016, depareime com descobertas que mostraram trilhas por vezes tortuosas, mas que me levaram a um caminho bem construído em prol da configuração do conhecimento sobre turismo rural no Estado de São Paulo, inserido nos cenários brasileiro e mundial.

Com esse propósito realizei uma cuidadosa revisão documental e bibliográfica acerca da experiência de turismo rural no Estado, de modo que fosse possível observar as dimensões - acadêmicas, sociais, urbanas, rurais, que influenciaram na sua trajetória. Neste sentido a análise das teses e dissertações que abordaram diferentes aspectos do turismo no espaço rural paulista trouxeram uma importante contribuição ao revelar as perspectivas e os interesses dos pesquisadores e também suas contribuições ao entendimento desse processo. 
Por outro lado, a análise dos resultados gerados por estudos realizados por diferentes entidades como SEBRAE (Serviço Nacional de Apoio ao Pequeno Empreendedor), IBGE (Instituto Brasileiro de Geografia e Estatística), IICA (Instituto Interamericano de Cooperación para la Agricultura), IDESTUR (Instituto de Desenvolvimento do Turismo Rural), e dos dados de um levantamento realizado pela ABRATURR-SP (Associação Brasileira de Turismo Rural, em São Paulo), em 2014, junto aos empreendedores de turismo rural permitiram desvendar algumas características do negócio do turismo rural no Estado. Esta discussão está estruturada em três capítulos, o primeiro que traz uma reflexão acerca do momento do turismo rural no mundo e no país e as implicações decorrentes das profundas transformações na relação urbano-rural, na presença inexorável da tecnologia e de como o turismo rural se insere no universo da atividade turística, incorporando as peculiaridades da área como atividade econômica.

O segundo capítulo apresenta uma discussão a partir do olhar múltiplo, de um lado a contribuição dos pesquisadores que se preocuparam em compreender a experiência multifacetada do turismo no espaço rural paulista, articulada com uma apreciação temporal e com diferentes perspectivas. Por fim, no terceiro capítulo aborda-se a questão do turismo rural sob uma óptica operacional, com intuito de "esclarecer" a dinâmica e estrutura dos empreendimentos de turismo rural enquanto negócio.

A elaboração deste documento não é o final desta viagem. Mas certamente a sua autoraprotagonista conseguiu amadurecer algumas ideias, sossegar uma parte das inquietações e, ao mesmo tempo, encontrar forças e estímulo para prosseguir no aprofundamento dos estudos, com novas indagações. Para isso, os convido, mais do que simplesmente compartilhar das minhas análises e reflexões, mas sim provocar e estimular a percepção de um emergente e promissor campo de estudos para juntos contribuirmos na construção do conhecimento sobre o turismo rural em suas aplicações teórico-práticas na realidade paulista. 
1 Turismo Rural: Evolução dos

Estudos e Interfaces com o Mercado 


\subsection{Evolução dos estudos na relação entre turismo e ruralidade}

O retorno a um rural idílico e nostálgico era usualmente tema de muitas canções de sucesso como essa de Cascatinha e Inhana, ícones da música sertaneja nas décadas de 1950 e 1960, até hoje referência para aqueles que gostam do gênero. Esta relação afetiva, saudosa de uma vida no campo a qual não mais se tinha acesso, ainda tem força no imaginário tanto daqueles que a viveram em algum momento de sua vida, quanto dos que nunca tiveram relações ou vivências diretas com esta realidade.

E de certo modo, ganhou força suficiente para estimular um movimento de busca pela vivência, mesmo que por restritos períodos de tempo, na área rural. Alguns poderão dizer que isto sempre existiu, refletido inclusive pelas segundas residências presentes na vida dos citadinos romanos, nos burgueses europeus e em muitos outros lugares, ao longo de séculos. Se assim fosse ainda, não haveria razão para este movimento identificado como turismo rural, 
ter se tornado uma temática de interesse de empreendedores, de organizações nacionais e internacionais, do poder público, dos pesquisadores e muitos outros interessados direta ou indiretamente, principalmente pelos efeitos que provoca.

Se por um lado se observava um movimento de pessoas se dirigindo às áreas rurais, por outro este era/é um espaço que vive imerso em um profundo processo de transformação, caracterizado por muitas perdas. Nesse cenário alguns proprietários rurais perceberam nesse interesse dos moradores dos centros urbanos, uma oportunidade para se renovar e manter seu estilo de vida e tradições.

Em alguns países europeus, como França, Espanha e Reino Unido, estas experiências são relatadas por inúmeros investigadores desde meados do século XX. Sharpley (2004, p. 374), por exemplo, ressalta que desde da década de 1960 o turismo rural tem emergido como um elemento significativo no total da atividade turística. Assim, a experiência europeia destacase pela magnitude que alcançou tanto no fluxo de visitantes gerado quanto na quantidade de empreendimentos envolvidos (Pulido Fernandez, 2008a), e também pelo suporte de financiamento e apoio de políticas públicas diversas ao segmento, como o programa LEADER $^{2}$ (Hjalager, 1996).

A consolidação do turismo rural em vários países europeus gerou uma série de investigações, razão pela qual só havia acesso às discussões sobre turismo rural na perspectiva da experiência europeia e norte-americana, quadro tem se alterado consideravelmente nos últimos anos, seja pelo incremento do turismo rural em diversos outros países de diferentes

\footnotetext{
2 Trata-se de uma iniciativa da comunidade europeia que destina recursos e apoio técnico para o desenvolvimento das áreas rurais, desde do início da década de 1990. Para mais informações, acessar $<$ http://ec.europa.eu/agriculture/rur/leaderplus/index_pt.htm>.
} 
continentes - na América Latina, Ásia e África -, seja pela inserção dos países do leste europeu no turismo mundial.

Contudo esta realidade tão diversa está pouco representada nos artigos publicados nos periódicos de turismo internacionais, leia-se anglo-saxões. Orsolya (2015), ao analisar a pesquisa de turismo rural nos últimos quinze anos, verifica que 54,55\% das regiões estudadas estão nos países europeus, seguidas pelos países asiáticos (31,31\%), e o restante na América do Sul, Austrália e África. Seguramente não se deve tomar este resultado só por este recorte, uma vez que existe grande a quantidade de estudos publicados em periódicos de acesso livre e outras publicações em outros idiomas, como o espanhol e português.

Estudos desta natureza, como o de Orsolya (2015), contribuem para reconhecer os avanços e as prioridades de pesquisa em várias áreas do conhecimento, ao oferecer um panorama das temáticas, metodologias e mesmo identificar os pesquisadores que têm se dedicado à determinadas questões e sinalizar novas abordagens. Neste sentido, Sharpley (2004) apontava no início da década de 2000 quatro temas de pesquisas que considera emergentes:

- discutir as transformações que se operavam na relação entre as localidades rurais e as urbanas, e também entre as diferentes localidades rurais e o desenvolvimento do turismo rural;

- reconhecer as novas formas de turismo que estão sendo implementadas nas áreas rurais, especialmente para subsidiar uma gestão estratégica adequada;

- entender o turismo como um elemento integrante da economia rural e por isso deveria ser inclú́do no desenvolvimento das políticas rurais tanto no âmbito nacional como no regional;

- refletir sobre os riscos da "insustentabilidade", com o objetivo de otimizar o papel do desenvolvimento do turismo na área rural dentro de parâmetros ambientais, considerando também o seu uso recreacional. 
Nota-se que há uma preocupação em pensar o rural com o turismo, como se tratassem de uma simples questão de reconhecer a presença do negócio turístico no ambiente rural. Mas não se trata só disso. Tem-se aqui dois contextos distintos e complexos que ao ganhar uma maior proximidade na convivência cotidiana faz aflorar uma série de conflitos, os quais têm sido observados e analisados pelos pesquisadores de diferentes áreas do conhecimento, como antropologia, meio ambiente, economia, patrimônio, entre outros.

Uma breve reflexão sobre esta realidade provoca uma série de indagações. Como conseguir avançar em uma leitura tão complexa que precisa articular os estudos sobre o universo agrário, considerando sua diversidade espacial, econômica, social, histórica e cultural com a discussão de turismo tanto na sua abordagem operacional (conformação de produtos e serviços, comercialização) quanto na econômica (relações de oferta e demanda)? A isso ainda agrega a necessidade de se compreender os efeitos deste fluxo de visitantes nas comunidades rurais, além de examinar como as mudanças sociais e de comportamento têm influenciado este movimento de retorno ao campo por parte não apenas do visitante como também do novo morador ${ }^{3}$.

Lane (2014) faz uma provocação classificando os estudos sobre turismo rural em três tipos: os críticos que atentam para os perigos de comodificação das culturas tradicionais e a degradação ambiental, aqueles preocupados em analisar as percepções dos residentes sobre a presença do turismo e por fim os que estudam medidas de impacto econômico, social e ambiental . Obviamente é uma análise reducionista das discussões acerca da temática, mas tinha o intuito de apontar para questões fundamentais que não estavam na pauta dos investigadores, como a necessidade de uma abordagem proativa, com descobertas de

\footnotetext{
${ }^{3}$ Vários pesquisadores tem observado um movimento de repovoamento das áreas rurais, e não se trata do retorno daqueles que se mudaram para os centros urbanos, mas de uma população eminente urbana que decide mudar de estilo de vida e opta por viver nesses espaços em busca de qualidade de vida. Estas pessoas estão sendo denominadas como neorurais ou rurbano.
} 
pesquisa que levem a desenvolvimentos tangíveis e possa estimular os pesquisadores a compartilharem seus trabalhos, seus pensamentos e os recursos financeiros.

Trata-se e uma proposta tentadora, que já está em processo mais avançado em algumas áreas do que em outras, mas que depende da quebra de paradigmas em vários âmbitos (pessoais, institucionais e entre países) e, principalmente, de facilidades para aqueles que ousarem trabalhar neste formato. Esta questão é custosa aos pesquisadores latino-americanos em geral, de um lado pela fragilidade de nossas instituições de pesquisa e da nossa própria produção científica, decorrentes dos inúmeros problemas com os quais tem-se que conviver cotidianamente, acentuado pela ausência de recursos e pela barreira do idioma. Por outro lado, um forte questionamento de como seria nossa inserção nessas discussões internacionais, onde é recorrente a tentativa de replicar modelos norte-americanos e europeus para nossas realidades.

Estas questões foram apresentadas por Pearce (2014, 2012), e logo em seguida criticadas por Korstanje (2014), e ainda são pontos de pouca unanimidade. Afinal, estariam os colegas europeus abertos efetivamente a um compartilhamento de experiências e de visões de mundo? E os pesquisadores latino-americanos conseguirão superar a força de uma cultura colonialista que ainda hoje marca a autoestima e os relacionamentos entre os países? Certamente uma discussão estimulante, mas que não está no escopo deste estudo.

Mesmo com as fragilidades apontadas por Lane (2014), é possível observar temas que são comuns, embora tratem de diferentes experiências. Orsolya (2015) analisou 102 artigos e verificou que $21,57 \%$ deles tratavam de temáticas relacionadas ao desenvolvimento do turismo rural ou à reestruturação rural de áreas interessadas em turismo. Os estudos sobre impactos do turismo que estão fortemente relacionados a temas de sustentabilidade representavam 13,73\%, assim como aqueles que discutiam a geração de condições de 
sustento, capital humano e identidade local (13,73\%), além de uma extensa lista indicando outras temáticas com menor presença; no total foram identificados 21 temas.

Conclui que a tarefa de identificar categorias que possam caracterizar a pesquisa sobre turismo rural é árdua, uma vez que muitos temas tendem a se sobrepor. Ainda revela uma prevalência de estudos que têm como figura central a oferta de turismo rural, enquanto questões de demanda são negligenciadas. (Orsolya, 2015)

Mesmo em momentos diferentes de trajetória evolutiva e com foco em outro contexto agrícola e cultural com poucas facilidades para a implementação do turismo rural, um estudo sobre produção científica acerca do tema no Brasil (Solha, 2012) apresentou resultados semelhantes aos verificados por Orsolya (2015) e com a situação apontada por Lane (2014).

Pode-se considerar que estes são indicadores relevantes das inquietudes dos pesquisadores sobre este objeto de estudo, e que a prevalência de certas temáticas está naturalmente associada à capacidade já identificada do turismo rural de regenerar áreas rurais em declínio, que em muitos momentos aparece como uma panaceia para os problemas estruturais do setor agrícola. (Froehlich, 2000)

No entanto, alguns estudos e publicações têm sinalizado para novas questões, várias delas apresentadas por Lane (2014) como desafios para o futuro próximo, com destaque para a inevitável mudança de perspectiva. Ou seja, o turismo rural deverá ser entendido sob um enfoque integral (Kastenholz et al., 2014; Saxena \& Ilbery, 2010; Varisco, 2016), o que significa que "mudará o foco de um turismo rural baseado em empresas únicas que atuam sozinhas para um turismo rural baseado em destinos, com empresas que aprendam a trabalhar juntas" (Lane, 2014, p. 30).

Esta pode ser uma estratégia interessante para superar uma das restrições do turismo rural, a operação em pequena escala, com uma oferta restrita de produtos e serviços. Para Pulido 
Fernandez (2014), tal mudança deverá se apoiar na inovação da oferta, por meio da segmentação (inteligência de mercado e inovação) e da cooperação entre os empreendedores ou entre os turistas, se organizando em grupos ou redes de compra/venda.

Tem-se que considerar que este cenário tem se delineado ao longo das últimas décadas em decorrência de alguns processos denominados como "neo-ruralidades", que representa por uma lado o entendimento "do rural como parte de um território alargado, globalizado e urbanizado, e também como parte de um processo histórico de movimentos de população, e não como uma categoria absoluta e oposta ao urbano" (Cristovão, 2012, p. 2). A melhor representação são os novos habitantes da área rural, que são novos camponeses, neorurais e rurbanos e que têm adquirido um importante protagonismo nos velhos espaços rurais. Se o “turismo rural pode ser visto como uma invenção do mercado e do poder dominante para redefinir o espaço rural, cada vez menos agrário e mais urbanizado", como ressalta Cristovão (2012, p. 3), então questões como operação, comercialização, oferta e demanda, e competitividade passam a ser percebidas como parte de seu cotidiano.

\subsection{Percepção de um Universo em transformação}

As percepções acerca da transformação do universo rural também têm sido amplamente discutidas no país e a presença de novos atores neste espaço têm provocado algumas mudanças de paradigmas na leitura oficial da realidade. O IBGE - Instituto Brasileiro de

\footnotetext{
${ }_{4}^{4}$ Tema da 8 a edição do Citurdes, em Chaves, Portugal.
} 
Geografia e Estatística (2011), no último censo agropecuário assume a necessidade de um olhar para o campo que considere as mudanças em processo e afirma o seguinte:

O rural transcende o agropecuário, não produz somente alimentos, produz trocas que ocorrem no âmbito do fornecimento de alimentos, de seu armazenamento e distribuição na pesquisa, no financiamento etc. Nessa análise a pluriatividade constitui uma realidade cada vez mais presente no campo, aí se destacando novas atividades relacionadas com lazer, com turismo ecológico e rural e com as outras modalidades de uso não agrícola do espaço rural, além de uma diversidade de novas atividades relacionadas com a jardinagem, haras, etc.[...]. (p. 243)

Enfim, não é uma realidade só percebida e estudada por aqueles que estão diretamente relacionados a ela, pois tem emitido forte sinalização de sua presença em vários estudos que analisam o desenvolvimento rural no país (Silva \& Grossi, 2000; Veiga, 2001; Wanderley, 2000, 2001). Contudo ainda não se manifesta com toda sua plenitude, pois estes estudos distinguem apenas alguns indicadores de que há um movimento em expansão, com destaque para o incremento dos domicílios rurais de uso ocasional entre 2000 e 2010, especialmente nas regiões nordeste e sudeste (Figura 1). 


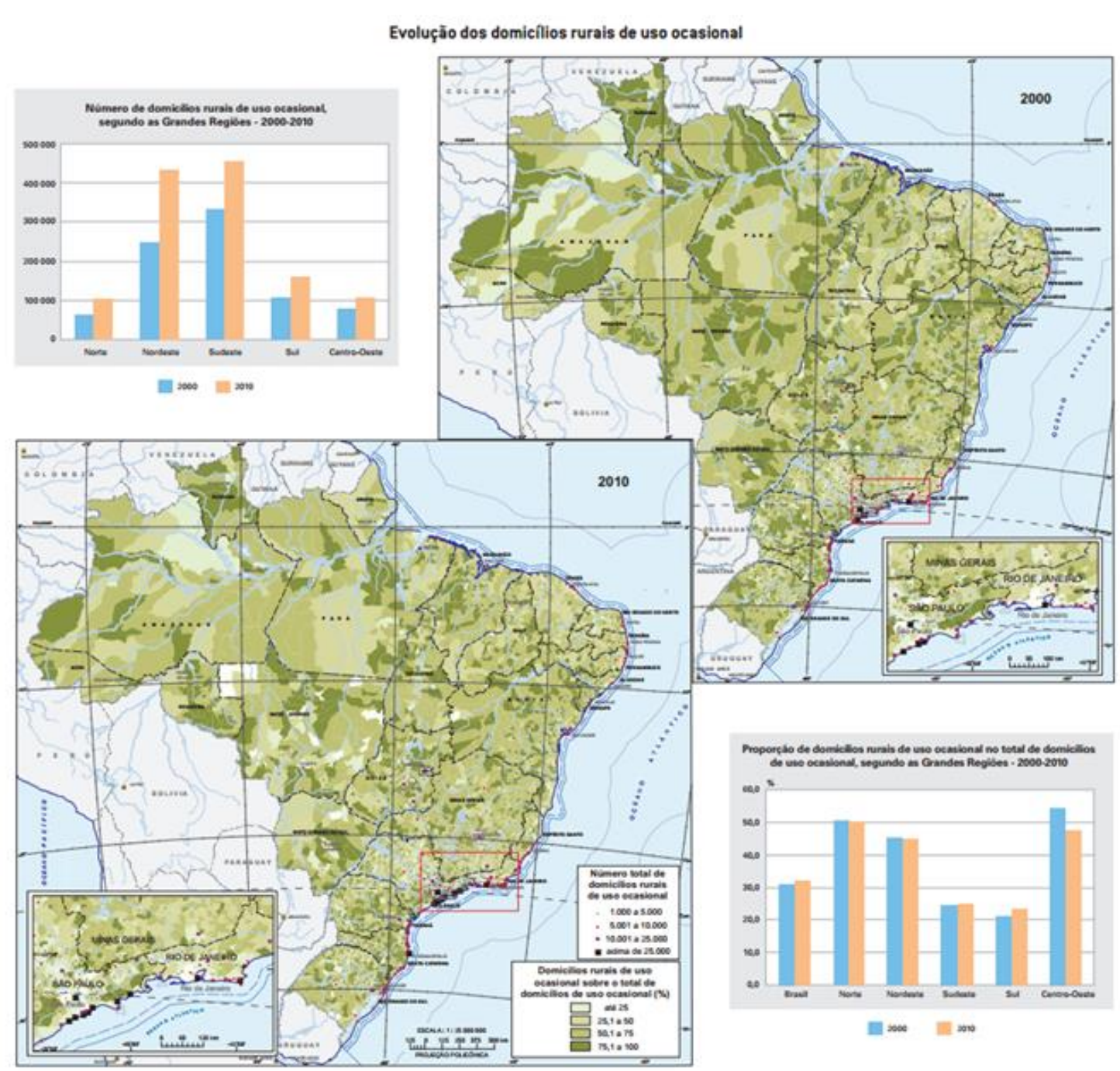

Figura 1 - Evolução dos domicílios rurais de uso ocasional 2000-2010

Nota. Fonte: IBGE (2011).

Ressalta-se que:

O espaço rural abriga, cada vez mais, o turismo sofisticado, voltado para segmentos populacionais específicos, em especial, de origem urbana e marcado pela presença de domicílios de segunda residência em locais com amenidades e recreação (Wanderley, 2000 citado por IBGE, 2011, p. 243).

Em outros estudos acerca da presença cada mais intensa da pluriatividade nos espaços rurais, Silva e Grossi (2000) identificam o incremento de algumas outras atividades de lazer nas áreas rurais. 
Na última década milhares de pesque pagues proliferaram pelo interior. Nestes, a produção de peixes propriamente dita não é a maior fonte de renda, mas sim os serviços prestados nos pesqueiros, visando populações urbanas de rendas média e baixa. Também observa a expansão das construções rurais para a segunda moradia das famílias urbanas de rendas média e alta, em chácaras e sítios de lazer no interior do Brasil. ( p. 166)

As atividades apontadas nestes estudos são apenas a "ponta de um iceberg", que não revelam a intensidade e a complexidade das atividades de lazer e de turismo presentes nas diferentes regiões rurais ${ }^{5}$ do país, uma vez que estas têm sido extensivamente examinadas e discutidas desde meados da década de 1990 por pesquisadores, gestores públicos, profissionais e empreendedores dedicados à discussão de turismo rural (Solha \& Rejowski, 2013).

Aqui cabe destacar que este quadro pode ser observado a partir de diferentes abordagens, a mais ampla que considera todas as atividades de lazer realizadas no espaço rural, denominada como Turismo no Espaço Rural ou Turismo nas Áreas Rurais, na qual estão as chácaras de lazer, os pesqueiros, os hotéis fazenda e outros, mas sem compromisso com a produção agrícola (Tulik, 2010); e, de outro lado, a abordagem que considera como Turismo Rural propriamente dito, como "o conjunto de atividades turísticas desenvolvidas no meio rural, comprometido com a produção agropecuária, agregando valor a produtos e serviços, resgatando o patrimônio cultural e natural da comunidade" (MINTUR, 2008, p.11).

Estas são algumas das diferentes formas de lazer e turismo que estão inseridas no ambiente rural (Sharpley, 2004), e comumente há uma grande dificuldade de compreender as diferenças entre elas e, consequentemente, mensurar sua dimensão. Assim o presente estudo se apoia na definição oficial de Turismo Rural, principalmente porque não se trata apenas de se estar fisicamente no espaço rural, mas de fato fazer parte dele e, portanto, estar comprometido

\footnotetext{
${ }^{5}$ No processo de alteração de paradigmas de suas análises do universo rural, o IBGE apresenta em 2015 um Relatório Técnico, em que explicita a mudança inclusive na nomenclatura, não tratando mais de Regiões Agrícolas, mas sim de Regiões Rurais. (IBGE,2015).
} 
com o seu desenvolvimento. Aqueles proprietários rurais que se inserem no universo do turismo como estratégia de complementação de renda percebem que isso traz uma série de vantagens que não exclusivamente econômicas, com um custo-benefício aceitável, como pode ser observado no Tabela 1.

Tabela 1 - Efeitos do Turismo Rural

\begin{tabular}{|c|c|}
\hline Efeitos & Exemplos \\
\hline \multirow{11}{*}{ Favoráveis } & $\begin{array}{l}\text { Efeito multiplicador dos gastos dos turistas, circulação de recursos e incentiva novos } \\
\text { empreendimentos }\end{array}$ \\
\hline & Gera muitas expectativas \\
\hline & Gera oportunidades de trabalho \\
\hline & Apoia-se na mão-de-obra familiar sem necessidade de saída dos jovens \\
\hline & Cria mercado de consumo local \\
\hline & Gera benefícios complementares como infraestrutura, lazer e associativismo \\
\hline & Estimula a participação das mulheres \\
\hline & Opera mudança no nível de vida das famílias \\
\hline & Comunidade percebe seu patrimônio a partir do olhar do turista \\
\hline & Promove a satisfação em viver na "roça" \\
\hline & Diminui a migração \\
\hline \multirow{4}{*}{ Desfavoráveis } & Volume pouco significativo de recursos/empregos gerados se considerar valores totais \\
\hline & Mais importante em locais com pouco dinamismo econômico \\
\hline & Inevitável se tornar principal ou única atividade econômica \\
\hline & Diminuição das relações sociais com a comunidade, em função dos tempos do turismo. \\
\hline
\end{tabular}

Nota. Fonte: Elaboração da autora com base em Elesbão (2014).

Curiosamente, a análise disponibilizada no Atlas do Espaço Rural Brasileiro (IBGE, 2011) não mostra muitos dados acerca da oferta de atividades de turismo rural nas unidades produtivas rurais. Contudo, Elesbão (2014) aponta que o Censo Agropecuário de 2006, publicado em 2009, conseguiu um primeiro mapeamento, identificando 3.551 propriedades 
rurais com receitas oriundas de atividades de turismo rural. Obviamente é um número muito reduzido de propriedades para um total de 5.175 .489 estabelecimentos, mas é a primeira informação consistente e oficial sobre o universo.

Embora se verifique a presença e uma tendência de expansão, vários autores alertam para os fatores que restringem o processo, entre eles as condições precárias do meio rural brasileiro, especialmente nas áreas de predomínio da agricultura familiar (Elesbão, 2014; Veiga, 2001). Outros, como Vilela (2013), apontam o cuidado que os proprietários devem ter no sentido de não atenderem a certas demandas dos seus clientes:

[...] em diversas ocasiões, os proprietários, ou gerentes, depararão, se é que já não depararam, com clientes querendo reproduzir o seu ambiente urbano no meio rural. Resistam. Mostrem a eles que ali há muitos ganhos em se distanciar da rotina mecânica dos hábitos urbanos. Se conseguirem é muito provável que resgatem mais um ser humano ao mundo da sensibilidade. Elembrem-se de que a música pode ter um papel importante nesse processo. (p. 218)

O texto acima traz uma discussão rara na área de turismo e ao mesmo tempo preciosa, ao se enveredar numa reflexão sobre o papel da música caipira no turismo rural. Isto porque acredita que aqueles que buscam estes espaços querem "fugir dos bordões urbanos de sons e barulhos que nunca param, quer[em] escutar o som da natureza e, sobretudo o som do silêncio [...] o som de si mesmo" (Vilela, 2013, p.217). Portanto estão prontos e ávidos por uma vivência única e memorável, da qual a música pode fazer parte, e assim, ao mesmo tempo em que ocorre este resgate para o mundo da sensibilidade, contribui para "a afirmação de nossos valores e retomada de uma consciência de quem somos" (Vilela, 2013, p. 220).

Intrigante como uma discussão sobre indústria cultural e música popular pode estar fortemente relacionada com umas das questões mais relevantes do turismo rural na contemporaneidade, a capacidade de oferecer uma experiência especial, e se constituir na maior e mais significativa motivação dos seus visitantes. 
Naturalmente, esta questão deveria estar na pauta dos pesquisadores e principalmente dos empreendedores que atuam no segmento. Como visto anteriormente, são poucos os estudos aprofundados acerca da demanda de turismo rural e que de modo geral apontam para perfis muito genéricos dos visitantes.

Ainda há pouca apropriação de dados que são sistematicamente divulgados por grandes consultorias de turismo acerca das transformações no comportamento do consumidor de turismo, e que certamente se refletem no consumo para qualquer segmento da atividade. De forma geral, é do senso comum dos profissionais de turismo que entre as novas características de comportamento está a interatividade, um consumo mais pensado, uma grande predisposição para buscar informação em fontes variadas, uma avaliação de preço baseada no valor da experiência e a personalização dos produtos e serviços. (Amadeus, 2015; Pulido Fernandez, 2014; Skift, 2015)

Menosprezo? Ignorância? Ou apenas desconhecimento? Talvez esta relação despreocupada dos empreendimentos de turismo rural com questões relacionadas a aspectos da comercialização seja decorrente das fragilidades da origem do negócio. Afinal o turismo rural é entendido como atividade complementar nas propriedades rurais, portanto, não necessitaria de investimentos ou mesmo de qualificação profissional. Talvez tal assertiva fosse verdadeira para os primeiros empreendimentos de turismo rural, mas seguramente não corresponde mais à atual realidade, como se discute a seguir. 


\subsection{Dinâmica e organização na ótica do mercado}

Pulido Fernandez (2014), em sua conferência de abertura do $9^{\circ}$ CITURDES (Congresso Internacional sobre Turismo Rural e Desenvolvimento Sustentável), propunha uma série de questionamentos acerca da tendência dos pesquisadores e dos empreendedores ignorarem que o turismo como atividade econômica é um setor muito complexo e que tende a ser cada vez mais profissional, e a inserção destes pequenos empreendedores rurais neste universo precisaria ser cuidadosa e planejada. Destacava que se trata de uma atividade de complexa administração (Pulido Fernandez, 2014), então como esperar que estes produtores rurais possam gerenciar um pequeno empreendimento num segmento que tem como desafios:

- ser rentável como uma estratégia de diversificação dos ingressos agropecuários tradicionais, utilizando os recursos ociosos tanto humanos como materiais;

- priorizar os investimentos na comercialização, promoção e marketing;

- participar de promoção coordenadas entre os diversos destinos, para fortalecer o produto em mercados internacionais;

- sustentar-se pela qualidade e não por preço, seu crescimento está relacionado não com a quantidade de pessoas, mas como um segmento exclusivo de turistas;

- agregar o valor turístico dos serviços e produtos regionais;

- ser competitivo e incrementar os ingressos com maiores índices de ocupação;

- estabelecer maior contato com os agentes de viagens para incrementar a comercialização nos mercados nacionais e internacionais;

- ter capacidade de organizar-se com aqueles que atuam no segmento. (OMT, 2003) 
Evidente tratar-se de uma tarefa quimérica para os empreendimentos individualmente, e que exige dos empreendedores uma série de competências e habilidades técnicas e comerciais, como destacadas por Oliveira (2004), tais como:

- ter visão de longo prazo;

- entender que se trata de um negócio de baixo retorno;

- aceitar que a privacidade da família será reduzida;

- ser capaz de coletar, associar e analisar informações;

- ter capacidade de investimento;

- ter carisma e hospitalidade;

- estar disponível para atender o turista 24 horas

- manter o interesse nas atividades produtivas.

A isto agregam-se outros fatores externos que podem ter forte impacto na operação dos negócios, ressaltados por Maldonado (2009) ao analisar as deficiências da oferta do turismo rural comunitário, mas que seguramente se aplicam à realidade do turismo rural em muitas localidades. Entre elas destacam-se a carência de estruturas e mecanismos regulares de cooperação interna; a escassa diversificação de produtos turísticos; a gestão profissional limitada, tanto operacional como gerencial, onde as tendências e o funcionamento da indústria turística são desconhecidos; a deficiência dos mecanismos de informação, comunicação e organização comercial; e o déficit notável de serviços públicos de transporte, energia, saneamento, comunicação e sinalização turística. Este cenário tem-se agravado diante do amadurecimento do segmento de turismo rural, que ganha maior expressão, visibilidade e se insere de fato como um segmento no mercado turístico, e, portanto, sujeito à sua dinâmica. 
Kastenholz (2011), reconhecendo estas limitações à atuação individual dos empreendedores, propõe que se implemente uma abordagem de marketing integrado e sustentável de destino, apoiado na capacidade da organização deste em redes, integrando e gerindo os recursos numa oferta consistente e criativa, para um mercado selecionado a partir de estudo de segmentação rigoroso. Esta ideia inicial foi implementada como um projeto de pesquisa interdisciplinar, denominado "Projeto ORTE", que tem contribuído para aprofundar as discussões sobre destinos rurais (Kastenholz, 2014).

Se por um lado a questão da estrutura e da dinâmica dos empreendimentos de turismo rural têm sido objeto de estudo de pesquisadores de vários países, que buscam entender como e de que maneira o turismo rural se insere no seu cotidiano (Barbieri \& Mahoney, 2009; Getz \& Carlsen, 2000), por outro observa-se o interesse em compreender a dimensão destes negócios no turismo do país, como é o caso da Espanha (Canoves et al., 2004; Instituto Geográfico Nacional, 2008; Pulido Fernandez, 2008b).

No Brasil, registram-se algumas iniciativas deste tipo, mas se deparam com alguns obstáculos significativos, como a ausência de dados estatísticos sobre turismo doméstico, situação contrária a espanhola, que gera e disponibiliza anualmente informações detalhadas sobre os movimentos turísticos dos espanhóis, na pesquisa intitulada "Familitur" ". Entre os estudos ressalta-se o “Diagnóstico do Turismo Rural en Brasil” (IICA, 2009), que busca compreender a dinâmica do segmento no país com foco institucional, identificando os aspectos conceituais, sinalização turística, organização administrativa e política, legislação, disponibilidade de financiamento e linhas de crédito.

\footnotetext{
${ }^{6}$ Projeto de pesquisa intitulado "A experiência global em turismo rural e desenvolvimento sustentável de comunidades locais" (em inglês The Overall Rural Tourism Experience and sustainable local community development - identificado pela sigla ORTE),

7 Pulido Fernandez utilizou estes dados em sua análise sobre a demanda de turismo rural europeu. Disponível em < http:// estadisticas.tourspain.es/es-es/estadisticas/familitur/paginas/default.aspx > . Acessado em 20 ago. 2015 .
} 
Em 2013, o SEBRAE Nacional apresentou os resultados do estudo intitulado "Retrato do turismo rural no Brasil com foco nos pequenos negócios", abordando diferentes temas como ambiente legal, incentivos, eventos nacionais e internacionais, mídias institucionais e segmentadas, oferta turística e perfil dos empreendedores de turismo rural (SEBRAE, 2013). Com a proposta de tecer um cenário nacional, se apoiou na base dados e informações oficiais do Ministério do Turismo, do Ministério do Desenvolvimento Agrário e nos documentos Destino Referência em Turismo Rural: Serra Geral (SC) e Caminhos do Brasil do Rural, além de documento interno do Ministério do Turismo com a listagem consolida dos participantes do edital do projeto Talentos do Brasil Rural - Turismo e Agricultura Familiar (Eixo Serviços). (SEBRAE, 2013)

Todo este esforço para identificar 122 propriedades que de alguma maneira estavam relacionadas formalmente nestes documentos, cujos dados foram analisados para gerar a análise da oferta turística. Para a análise do perfil empresarial considerou uma amostra de conveniência deste universo, de 50 empreendimentos, que responderam por telefone a um questionário com 36 questões (Silva, 2014).

Até o momento, esta é a única iniciativa conhecida de buscar informações mais aprofundadas sobre os empreendedores de turismo rural com abrangência nacional. Percebe-se que foi resultado de um admirável esforço de identificação de empreendedores e de coleta de dados, constituindo-se como uma importante contribuição para revelar um panorama dos negócios da área. Entretanto, os resultados obtidos podem não refletir a realidade de todas as unidades produtivas rurais que oferecem este tipo de atividade, porque o levantamento se restringiu apenas ao universo de propriedades que está inserido os projetos e programas do governo federal no período.

Anteriormente a este levantamento empreendido pelo SEBRAE Nacional (SEBRAE, 2013), tem-se o "Panorama Empresarial do Turismo Rural" (Roque, 2012), que traz os resultados 
de pesquisa realizada com os participantes da Rodadas de Negócio, nas edições de 2011 e $2012^{8}$, e apresenta informações sobre aqueles que ofertam produtos de turismo rural e sobre os operadores de turismo interessados na comercialização. A partir destes dois estudos é possível elaborar uma descrição das principais características dos empreendimentos, do negócio e ainda algumas indicações das fragilidades do segmento sob a perspectiva empresarial, como apresentado no Tabela 2.

Vale ressaltar, que embora tragam uma contribuição relevante para a identificação do perfil de empreendedores de turismo rural, estes dois documentos refletem a realidade daqueles empreendimentos com algum tipo reconhecimento do poder público federal, em função de participação em projetos e programas (SEBRAE, 2013), ou apresentam condições de negócios que permitem sua inserção na lógica de mercado (Roque, 2012). Portanto, não é possível generalizar os resultados como uma realidade nacional, que certamente é mais diversa e complexa.

Tabela 2 - Perfil empresarial dos empreendimentos de turismo rural brasileiros

\begin{tabular}{|l|l|l|}
\hline Item & Características & Fonte \\
\hline Empreendedor & $\begin{array}{l}\text { Faixa etária de } 40 \text { a } 59 \text { anos }(42,37 \%) \text {, seguido por } 25 \text { a } 39 \\
(28,81 \%) \text { e mais de } 60 \text { anos }(25,42 \%) \\
\text { Educação em nível superior }(45,76 \%), \text { médio }(27,11 \%) \text { e } \\
\text { fundamental (27,11\%) }\end{array}$ & $\begin{array}{l}\text { Sebrae } \\
(2013)\end{array}$ \\
\hline & $\begin{array}{l}\text { Tempo de atuação com turismo rural menos de } 5 \text { anos } \\
(27,12 \%), 5 \text { a } 10 \text { (30,5\%), 11 a 20 (20,3\%) há mais de 20 anos } \\
(22 \%)\end{array}$ & $\begin{array}{l}\text { Sebrae } \\
\text { Atividade familiar (88,1\%) }\end{array}$ \\
\hline
\end{tabular}

\footnotetext{
${ }^{8}$ Evento idealizado e realizado pelo IDESTUR com apoio do SEBRAE. A $4{ }^{\text {a }}$ Rodada de Negócios de Turismo Rural aconteceu durante o $38^{\circ}$ Encontro Braztoa em São Paulo. Em 2014, aconteceu nas dependências do Departamento de Relações Públicas, Propaganda e Turismo (ECA) como parte de uma estratégia de aproximação da universidade com os empresários do setor, as operadoras de turismo e as entidades representativas do segmento.
} 


\begin{tabular}{|c|c|c|}
\hline \multirow[t]{2}{*}{$\begin{array}{l}\text { Empreendimento - } \\
\text { atividade de turismo } \\
\text { rural }\end{array}$} & $\begin{array}{l}\text { seguida pela pecuária }(21 \%) \text { e lavouras }(13,8 \%) \\
\text { Atividades visitas a propriedade com integração às atividades } \\
\text { rurais }(61 \%) \text {, oferta de alimentação }(51 \%) \text {, colheita de } \\
\text { produtos }(39 \%) \text {, degustação da produção }(38 \%) \text {, passeios em } \\
\text { trilhar e/ou caminhadas }(32 \%) \text {, hospedagem }(31 \%) \text {, atividades } \\
\text { culturais }(22 \%) \text {. } \\
\text { Comercializa produtos da propriedade }(85,4 \%) \text { e de outras } \\
\text { propriedades }(43,9 \%)\end{array}$ & \\
\hline & $\begin{array}{l}\text { Atua no turismo rural há mais de } 10 \text { anos }(44 \%) \text {, de } 9 \text { a } 10 \\
(19 \%) \text {, de } 6 \text { a } 8(22 \%) \text {, de } 3 \text { a } 5(11 \%) \text {, de } 1 \text { a } 2(4 \%) \\
\text { Produtos ofertados: pousada rural }(63 \%) \text {, restaurante rural } \\
(56 \%) \text {, agroturismo }(56 \%) \text {, cavalgada }(52 \%) \text {, fazendas } \\
\text { históricas }(48 \%) \text {, hotel fazenda }(30 \%) \text {, aventura }(26 \%) \text {, outros } \\
(33 \%)\end{array}$ & $\begin{array}{l}\text { Roque } \\
(2012)\end{array}$ \\
\hline $\begin{array}{l}\text { Empreendimento - } \\
\text { formalização }\end{array}$ & $\begin{array}{l}\text { Tem a propriedade da terra }(93,1 \%) \\
\text { Tem algum tipo de formalização do negócio, PRONAF }(45 \%) \\
\text { e CNPJ (59\%) } \\
\text { Daqueles que tem CNPJ - } 68,5 \% \text { são microempresas, } 25,7 \% \\
\text { pequenos empresários e } 5,71 \% \text { grandes empresários (destaque } \\
\text { para os vinhedos) } \\
29 \% \text { utilizam crédito para investimentos - recursos do } \\
\text { PRONAF }(82 \%)\end{array}$ & $\begin{array}{l}\text { Sebrae } \\
(2013)\end{array}$ \\
\hline \multirow[t]{2}{*}{$\begin{array}{l}\text { Empreendimento - } \\
\text { geração de emprego e } \\
\text { renda }\end{array}$} & $\begin{array}{l}\text { Atividade familiar }(88,1 \%), \text { com } 3 \text { ou mais membros da família } \\
(86,6 \%) \\
\text { Não tem empregados }(46,4 \%) \text {, entre } 1 \text { e } 2(23,2 \%), 3 \text { ou mais } \\
(30,4 \%) \\
\text { É a principal renda da propriedade }(32,8 \%)\end{array}$ & $\begin{array}{l}\text { Sebrae } \\
(2013)\end{array}$ \\
\hline & $\begin{array}{l}\text { Faturamento até } \mathrm{R} \$ 180 \mathrm{mil}(63 \%) \text {, de } \mathrm{R} \$ 180 \text { a } 360 \text { mil (11\%), } \\
\text { mais de } \mathrm{R} \$ 540 \mathrm{mil}(22 \%)\end{array}$ & $\begin{array}{l}\text { Roque } \\
(2012)\end{array}$ \\
\hline $\begin{array}{l}\text { Empreendimento - } \\
\text { funcionamento }\end{array}$ & $\begin{array}{l}\text { Contam com fornecedores da comunidade local e entorno } \\
(69,2 \%) \text {, utilizam super/hipermercados }(48,1 \%) \\
\text { Preocupação com meio ambiente, gestão de resíduos, } 91,4 \% \\
\text { separam o lixo e } 88 \% \text { reciclagem de resíduos. }\end{array}$ & $\begin{array}{l}\text { Sebrae } \\
(2013)\end{array}$ \\
\hline
\end{tabular}




\begin{tabular}{|c|c|c|}
\hline \multirow[t]{2}{*}{$\begin{array}{l}\text { Empreendimento- } \\
\text { comercialização }\end{array}$} & $\begin{array}{l}\text { O empresário principal agente }(76,3 \%) \text {, entidades e } \\
\text { organizações }(33,9 \%) \text {, agentes locais ou agencias de viagem } \\
(22 \%) \text {. } \\
\text { Divulgação pelo próprio empresário }(75,9 \%) \text {, entidades e } \\
\text { organizações }(62,1 \%) \text {. Citam Prefeituras como divulgadoras } \\
(12 \%) \\
\text { Divulgação na internet: blog ou site }(81 \%) \text {, facebook }(36,2 \%) \text {, } \\
\text { e material impresso: folhetos }(63,8 \%) \text { e cartazes }(43,1 \%) \\
\text { Participação anual }(86 \%) \text { em feiras e eventos }(76,3 \%) \\
\text { Contato pós-venda e avaliação de satisfação }(91,5 \%) \\
77,6 \% \text { fazem parte de cooperativas, associações ou sindicatos. }\end{array}$ & $\begin{array}{l}\text { Sebrae } \\
(2013)\end{array}$ \\
\hline & $\begin{array}{l}\text { Segmenta os produtos }(70 \%) \\
\text { Divulgação: site ( } 85 \%) \text {, multimídia (45\%), mídias sociais }(15 \%) \\
\text { e material impresso folder ( } 89 \%) \text {, catálogo }(30 \%) \text { e outros } \\
48 \% \text { dos materiais em inglês, } 22 \% \text { espanhol, } 11 \% \text { francês } \\
\text { Participa de rodadas de negócios como Ruraltur, Summit } \\
\text { Abeta, Salão do Turismo, Braztoa e ABAV. }\end{array}$ & $\begin{array}{l}\text { Roque } \\
(2012)\end{array}$ \\
\hline \multirow[b]{2}{*}{$\begin{array}{l}\text { Empreendimento - } \\
\text { Clientes }\end{array}$} & Regional $(68,5 \%)$, nacional $(31,5 \%)$ & $\begin{array}{l}\text { Sebrae } \\
(2013)\end{array}$ \\
\hline & $\begin{array}{l}\text { Segmentos explorados melhor idade ( } 42 \%) \text {, pedagógico }(32 \%) \text {, } \\
\text { técnico-científico }(21 \%) \text {, cultural }(16 \%) \text {, famílias }(11 \%) \text {, uma } \\
\text { lista diversificada de outros... } \\
\text { Clientes regionais }(48 \%) \text {, estadual }(67 \%) \text {, outros estados }(74 \%) \\
\text { e internacional }(67 \%)\end{array}$ & $\begin{array}{l}\text { Roque } \\
(2012)\end{array}$ \\
\hline
\end{tabular}

Nota. Fonte: Elaboração da autora a partir de dados do SEBRAE (2013), Silva (2014) e Roque (2012).

Assim, verifica-se que esta inserção nos dois espaços, do poder público e dos negócios, pode estar fortemente relacionada à capacidade de gestão dos empreendedores, a maior parte com: algum tipo de formação superior e, portanto, com acesso a informação; no auge de sua vida 
produtiva, o que indica que o empreendimento é parte de seu estilo de vida; e longo tempo de atuação no segmento de turismo rural, alguns com mais de dez anos, o que significa experiência adquirida e maturidade do negócio. Mas parece que algumas carências têm restringido uma atuação mais profissional, uma vez que apontam para a necessidade de capacitação e qualificação em diversos níveis, com destaque para aquelas relacionadas à gestão dos negócios e uma melhor compreensão do mercado. (Roque, 2012)

No entanto, a informação relacionada à atividade de turismo rural no empreendimento traz dados pouco qualificados, genérica no estudo do SEBRAE Nacional e com conceitos pouco precisos no documento do "Panorama Empresarial". Compreende-se que atendem a uma demanda específica de informação, contudo a coleta de dados genéricos sobre os empreendimentos agrega informação de pouco valor.

Se os operadores de turismo e os turistas buscam um produto diferenciado (Roque, 2012), como a coleta deste tipo de informação acerca do que é ofertado por estes empreendimentos revela um produto diferenciado? No primeiro caso são apontadas uma série de atividades ofertadas, que se confundem entre aquilo que é serviço e o que pode ser atrativo (hospedagem, alimentação) que aparecem com grande predominância nos diferentes empreendimentos (SEBRAE, 2013). No segundo caso há a indicação de produtos oferecidos, em que destacam algumas modalidades de hospedagem e alimentação (Roque, 2012). Serão eles o diferencial dos empreendimentos? Onde está a experiência memorável?

Certamente, esta é uma situação sobre a qual os pesquisadores poderiam se debruçar, pois se trata de elaborar definições e categorias de análise que possam ser aplicadas aos estudos sobre os empreendimentos de turismo rural; e também de utilizar a terminologia de turismo adequada para diferenciar claramente produtos, serviços, recursos, atividades, atrativos, ou mesmo se dedicar a esclarecer com entende cada definição e/ou categoria analisada. E aqui 
residem as dificuldades que ainda persistem, inclusive na literatura científica sobre turismo (Rejowski, 1996).

Sobre a estrutura e a dinâmica de funcionamento dos empreendimentos, há uma indicação da valorização de algum tipo de formalização, diante das possibilidades do momento. Percebe-se que, mesmo no universo restrito destes levantamentos, existem situações muito distintas em relação à capacidade de geração de emprego e renda, e por isso talvez seja necessário organizar em categorias que considerar o aspecto quantitativo (faturamento, pessoas envolvidas, etc). Certamente um estudo deste tipo com maior abrangência poderia identificar os contrapontos e a diversidades dos empreendimentos de turismo rural no país.

Os dados indicam uma débil preocupação com questões de sustentabilidade, restrita a ações básicas como reciclagem de resíduos (Silva, 2014), situação também apontada pelos próprios empreendedores, que apresentam uma série de fatores que contribuem para tanto. Este quadro não se deve unicamente à ausência de comprometimento ou mesmo de percepção de resultados, mas também a informação sobre como isto poderia ser implementado nas propriedades. (Roque, 2012)

Por fim, há indicação de estratégias de comercialização e divulgação bastante tradicionais, que apontam os limites e as dificuldades da ação individual destes empreendimentos, amplamente discutida pelos pesquisadores. Curiosamente, no documento do "Panorama Empresarial" os empreendedores demonstram ter conhecimento dos gargalos e destacam a pouca experiência e facilidade para atuar de modo colaborativo. Além disto, citam uma forte resistência às novas ideias e tecnologias, junto com a dificuldade de acesso à informação e mesmo de disponibilidade de infraestrutura adequada, a ausência de recursos (financeiros e outros) para investir em material promocional, e o pouco conhecimento sobre estratégias de comercialização e divulgação. (Roque, 2012) 
Novamente, nos dois estudos constatou-se a clara preocupação em identificar a oferta e os empreendimentos, enquanto que sobre a demanda só buscam informação de origem e indicação de alguns segmentos. Certamente, os empreendedores têm informações mais qualificadas sobre seus visitantes, mas que não foram exploradas neste estudo, e que poderiam contribuir para revelar e pensar estrategicamente ações de comercialização e divulgação.

Os debates acerca do turismo rural tem evoluído rapidamente e também se tornado mais complexos à medida em que incorporam uma percepção interdisciplinar nos estudos e na prática. Nesse contexto se faz cada vez mais preemente desenvolver estratégias de aproximação entre os diferentes profissionais que se dedicam ao tema, especialmente os pesquisadores. Mas para tanto é necessário identificar e reconhecer as contribuições que advêm os inúmeros estudos realizados sobre o tema. No caso da realidade paulista, é também um exercício de resgate e reflexão sobre os caminhos que foram percorridos até este momento. 


\section{Estudos do Turismo Rural na Realidade Paulista}




\subsection{Delineando o cenário}

Apesar de já superados inúmeros obstáculos desde o momento da implantação das primeiras experiências de Turismo Rural no país, na década de 1980, ainda são muitas as dificuldades. Dentre elas está a necessidade de um melhor entendimento a respeito das características e dos efeitos do desenvolvimento do turismo no meio rural, especialmente aqueles relacionados aos aspectos sociais e culturais, além de outras dificuldades identificadas pelo Ministério do Turismo, tais como: “[...] a falta de critérios, regulamentações, incentivos e outras informações que orientem os produtores rurais, os investidores e o próprio Governo são as causas de um segmento impulsionado quase que por completo pelas oportunidades de mercado" (MINTUR, 2004, p. 6).

A importância da pesquisa científica sobre a temática tem sido reconhecida sistematicamente por aqueles que atuam no segmento do turismo rural, desde 1998, ao ser expresso na "Carta de Santa Maria”, que afirmava: "não [há] confiabilidade nos registros existentes e a modesta quantidade de pesquisas acarretam uma morosidade no desenvolvimento socioeconômico no espaço rural" (MINTUR, 2004, p. 25); e na década seguinte a "Carta de São Paulo"” ressaltava que "uma crescente produção científica e acadêmica de pesquisa e de investigação dos últimos anos tem contribuído para o conhecimento e a compreensão do fenômeno do turismo rural, suas implicações e impactos nas diversas áreas".

Mesmo com esse avanço, o conhecimento da realidade do Turismo Rural no país é ainda bastante restrito, conforme aponta estudo realizado por Solha (2012, p.170), ao verificar que

\footnotetext{
9 Carta de São Paulo. 1a Feira Nacional de Turismo Rural. Disponível em: http://www.idestur.org.br/download/L_CARTA_SP_2004.pdf
} 
poucas regiões do país contam com estudos sistemáticos sobre a experiência de turismo rural. Com base nos dados desse trabalho elaborou-se a Figura 2 que mostra a produção científica brasileira sobre Turismo Rural por estado e períodos.

Observa-se uma tendência ascendente da produção de 1997 a 2010, que se inicia com 7 pesquisas de 1997 a 2000, 82 de 2001 a 2005, e 90 de 2006 a 2010. Entre os estados produtores destaca-se o Rio Grande do Sul (34) com um incremento significativo dos estudos a partir de 2001, resultado fortemente associado às investigações realizadas no âmbito da linha de pesquisa Mercado de Atividades Não-Agrícolas do programa de pósgraduação em Desenvolvimento Rural da Universidade Federal do Rio Grande do Sul, o qual também é responsável pela organização do CITURDES - Congresso Internacional sobre Turismo Rural e Desenvolvimento Sustentável (Solha, 2012).

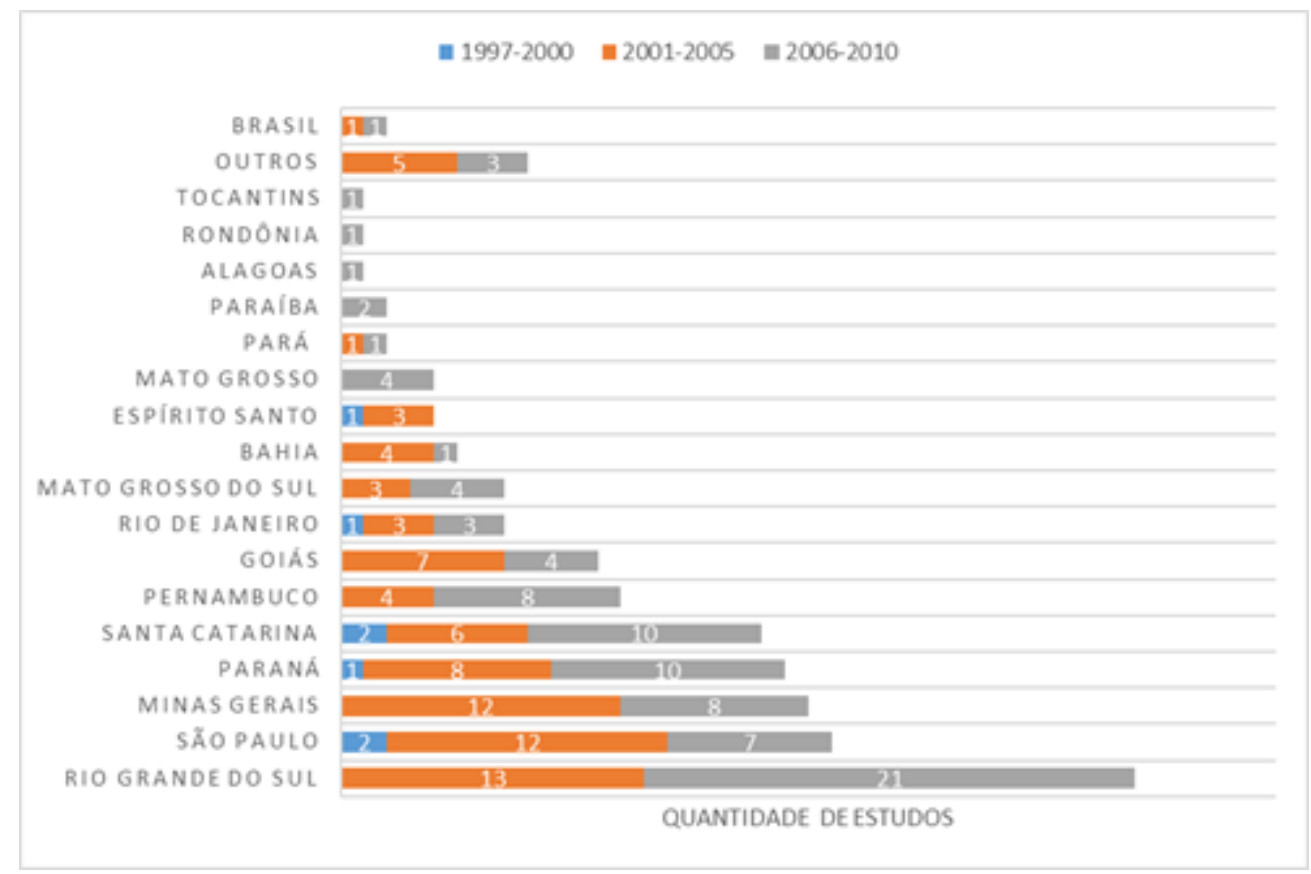

Figura 2 - Produção científica brasileira por período e por área objeto de estudo

Nota. Fonte: elaboração da autora com base em Solha (2012).

Em seguida se destaca a produção oriunda dos estados de São Paulo (21), Minas Gerais (20), Paraná (19), Santa Catarina (18), Pernambuco (12), Goiás (11), Mato Grosso do Sul (7), Bahia 
(6), Espírito Santo (4) e Mato Grosso (4). Destes apenas 5 estados têm estudos nos três períodos indicados, o que sugere a possibilidade de uma análise temporal de sua evolução. $\mathrm{O}$ item outros (8) reúne pesquisas que não têm como proposta analisar uma área em especial, mas temáticas, e somente duas investigações tratam do turismo rural sob uma perspectiva nacional: enquanto Vieira (2005) discute a política e a legislação para o turismo rural, Santos (2008) traz uma contribuição valiosa ao relacionar estas políticas com a implantação da atividade nos diferentes estados brasileiros.

No entanto, apesar de existir registros da implantação de negócios de turismo rural desde 1984 (Figura 3), os mesmos só passam a ser de interesse dos pesquisadores no final da década de 1990.

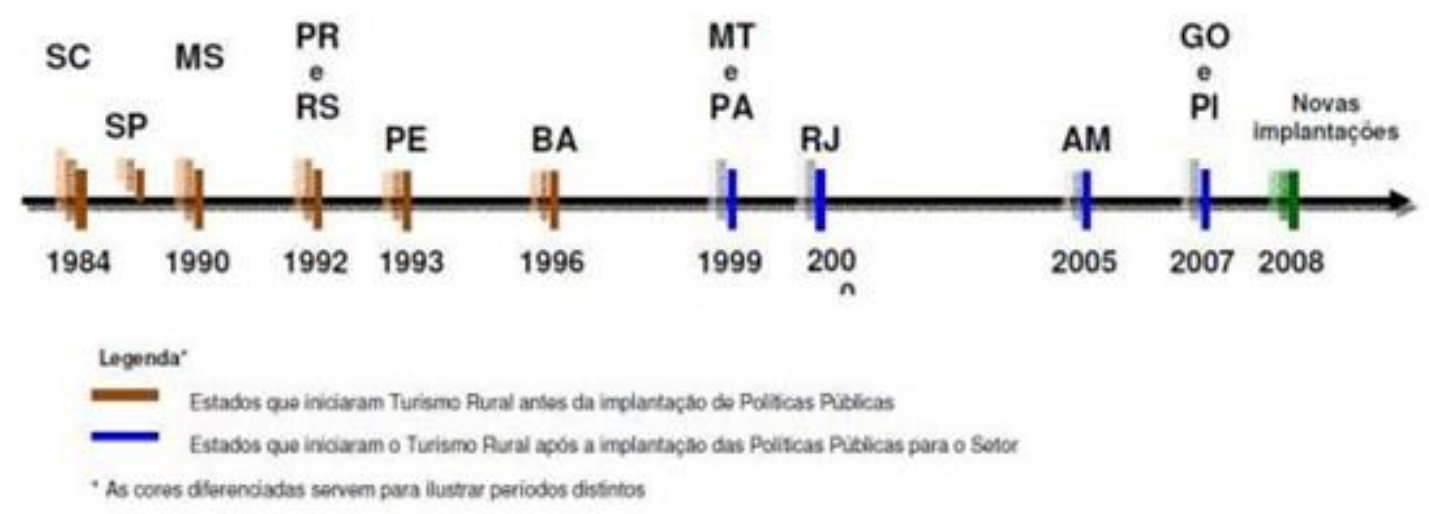

Figura 3 - Linha do Tempo - surgimento do Turismo Rural

Nota. Fonte: Santos (2008, p. 95).

De certa forma os resultados obtidos no estudo de Solha (2012), confirmam e validam a percepção de Tulik (2003, p. 12) ao afirmar que "na verdade, exceção feita às áreas em que o Turismo Rural está organizado, pouco se conhece sobre essa atividade no restante do território brasileiro". Mas também indicam que existem outros fatores que restringem ou estimulam a busca à abrangência dos estudos, como a proximidade das universidades com pesquisadores interessados na temática, a existência de atividades de turismo rural já 
implementadas (Solha, 2012) e a concentração dos estudos em áreas denominadas por Théry e Mello (2005, p. 144) como zonas modernizadas, de diversificadas a razoavelmente diversificadas, situadas na região sul, sudeste e nordeste do país.

A distribuição espacial das áreas de estudos é um indicador dos limites desse desenvolvimento, que, no entanto, precisa ser aprimorado e aprofundado, com o mapeamento do turismo rural no país, ou mesmo a realização de estudos que comparem os dados dos censos agropecuários com os dos censos do IBGE (Instituto Brasileiro de Geografia e Estatística), e possam oferecer um panorama das áreas que poderiam implementar projetos de desenvolvimento em que o turismo fosse uma das estratégias (Solha, 2012).

Um estudo dessa magnitude demandará um esforço coletivo de pesquisadores da área no longo prazo. Mas certamente os resultados poderão emergir indicadores importantes sobre as diferenças na configuração do turismo rural no país, subsidiar as políticas públicas para o segmento e atender às estratégias de fomento e disseminação de conhecimento indicadas na "Diretriz 2 - Informação e Comunicação, estabelecida no Documento com as Diretrizes para o Desenvolvimento do Turismo Rural”. (MINTUR, 2004).

Contudo, devido às marcantes diferenças regionais, ainda não se dispõe de metodologia que permita realizar o mapeamento da atividade no país. Assim os poucos pesquisadores que ousaram propor uma caracterização do turismo rural por região conseguiram identificar apenas elementos genéricos, como, por exemplo, o estudo de Portugues (2005) que identifica os seguintes elementos comuns do Turismo Rural em algumas áreas:

- em Santa Catarina, Rio Grande do Sul, Paraná e Espírito Santo, em função da forte imigração europeia, se mescla com o Turismo Cultural e com o turismo em cidades históricas; 
- no Vale do Paraíba (São Paulo e Rio de Janeiro) e em Minas Gerais, está intensamente relacionado com a produção cafeeira e com as propriedades de caráter histórico;

- no Centro-Oeste, vincula-se à natureza, principalmente com as atividades de lazer como pescaria e esportes radicais;

- no Nordeste, destaca-se o Turismo Sertanejo, baseado nos antigos caminhos de tropeiros pelo interior;

- na região Norte, sugere a vinculação à natureza e às culturas cabocla e indígena.

Diante de um cenário, que ao longo do período se tornou mais complexo e diverso, seja pelo surgimento de novas estratégias de gestão comunitária do turismo ou mesmo pela diversificação dos produtos e serviços oferecidos, o desafio de compreender a dinâmica do Turismo Rural no país se torna impreterível.

Uma estratégia possível para iniciar este processo é trabalhar a partir de uma perspectiva estadual, uma vez os governos estaduais geram sistematicamente dados sobre economia, demografia entre outros estudos, dos quais podem ser extraídas informações que permitam elaborar um panorama do turismo rural em cada estado brasileiro.

Mas quais são os fatores que determinam e configuram o turismo rural em cada estado brasileiro? Quais seriam as variáveis relevantes? Qual o conhecimento disponível acerca do assunto? Para dar conta destas inquietações é que se propôs analisar os estudos que tratam do turismo rural em São Paulo com o objetivo buscar subsídios para delinear um panorama da evolução e das características deste segmento do turismo; e ainda verificar que novos conhecimentos e questões emergem das diferentes abordagens e análises propostas nestas pesquisas. 


\subsection{Percurso metodológico}

Afinal são muitas as variáveis que definem e configuram a experiência de turismo rural em cada localidade ou região. Quais são as áreas e os objetos destas pesquisas? Quais são os recortes temáticos destes estudos? Que novos conhecimentos e questões emergem destas diversas análises? Estas são as questões que nortearam a análise do conteúdo da produção científica brasileira sobre o tema com foco no estado de São Paulo.

Para a definição de uma metodologia adequada a ser aplicada neste estudo sobre a produção científica com foco nas pesquisas científicas, foram ponderados diversos modelos metodológicos, com destaque para os estudos de revisão, estudos métricos e estudos do estado da arte.

Nos estudos de revisão, quer sejam quantitativos, como a meta-análise, quer sejam qualitativos, como a revisão integrativa, tem-se a sintetização e sistematização de um conjunto de pesquisas para encontrar alguma ordem ou verdade científica na grande profusão de literatura científica, identificando e comparando resultados, metodologias, abordagens teóricas, entre outros aspectos.

Os estudos métricos, como o próprio nome indica, referem-se a estudos que medem a informação científica mediante aplicação de métodos quantitativos, a fim de proceder análises estatísticas e matemáticas de publicações e atividades científicas, buscando a construção de indicadores de produção científica. Constituem campo da Ciência da Informação em seus subcampos, como os da Bibliometria e da Cienciometria.

Mas são os estudos chamados de estado da arte ou estado do conhecimento que se relevaram propícios de serem aplicados nesta pesquisa. Tais estudos inventariam e avaliam a produção científica "em um determinado campo de conhecimento", examinam "os autores e seus 
estudos, as tendências, as diversas perspectivas teóricas e metodológicas, os desafios existentes", analisam "aspectos e dimensões que vêm sendo privilegiados em distintas épocas e sociedades", e identificam "lacunas de conhecimento" e "possibilidades/necessidades futuras de desenvolvimento dos estudos", conforme explica Ferri (2011, p. 35). Constituemse como pesquisas de caráter bibliográfico ou documental, que buscam

[...] responder que aspectos e dimensões vêm sendo destacados e privilegiados em diferentes épocas e lugares, de que formas e em que condições têm sido produzidas certas dissertações de mestrado, teses de doutorado, publicações [...]. Também são reconhecidas por realizarem uma metodologia de caráter inventariante e descritivo da produção acadêmica e científica sobre o tema que busca investigar, à luz de categorias e facetas que se caracterizam enquanto tais em cada trabalho e no conjunto deles, sob os quais o fenômeno passa a ser analisado. (Ferreira, 2002, p. 258)

Estudos deste tipo de caráter quali-quantitativo, embora não rotuladas como estado da arte, vêm sendo desenvolvidos na área do Turismo desde a década de 1990 (Rejowski, 1993) e da Hospitalidade a partir da segunda metade dos anos de 2000 (Bastos, 2005; Fedrizzi, 2008), com base principalmente em dissertações de mestrado e teses acadêmicas. Em geral trabalham com os títulos, resumos e palavras-chave dos documentos selecionados, extratos que são tratados por meio da análise de conteúdo, conforme Bardin (1995).

Face a tais considerações, adotou-se o método de estado da arte para investigar a produção científica sobre turismo rural paulista, cuja primeira etapa centrou-se na definição dos critérios de busca, identificação e seleção das pesquisas acadêmicas, consideradas objetos de estudo.

Neste momento percebeu-se que fazer um recorte no Estado de São Paulo, com base apenas nos dados coletados anteriormente na pesquisa de Solha (2012), que tratou da produção científica brasileira sobre turismo rural, não seria suficiente. Assim, buscou-se atualizar e aprimorar este levantamento com a identificação de teses, dissertações, artigos e pesquisas 
que trouxessem alguma discussão sobre o turismo rural paulista. Para tanto, realizou-se uma extensa busca nas bibliotecas das universidades paulistas (USP, UNESP, UNICAMP, UFSCAR, UAM), na base de teses da Coordenadoria de Aperfeiçoamento do Ensino Superior (CAPES) e do Instituto Brasileiro de Informação, Ciência e Tecnologia (IBICT), além de trabalhos publicados nos anais dos congressos específicos da área, nos artigos de periódicos científicos de turismo e de outras áreas disponíveis na base SciElo ${ }^{10}$, e em documentos de órgãos públicos e organizações da área.

Porém, tendo em vista que em geral os artigos de periódicos, trabalhos de anais de eventos e outras publicações qualificadas se originam de pesquisas desenvolvidas em programas de mestrado e doutorado, portanto no âmbito da pós-graduação stricto sensu, restringiu-se o presente estudo às teses de doutorado e dissertações de mestrado que corresponderam à busca pelas seguintes palavras-chave: turismo rural, turismo no espaço rural e turismo em áreas rurais, associadas a São Paulo (estado) ou paulista. Com relação às outras publicações, estas foram utilizadas posteriormente, ora reforçando, ora contrapondo os resultados da produção científica do turismo rural no Estado de São Paulo.

Os dados das pesquisas acadêmicas selecionadas foram registrados em uma ficha técnica adaptada de Rejowski (1993) na forma de planilha, contendo as suas características gerais, ou seja, título, autor, tipo (dissertação de mestrado ou tese de doutorado), instituição produtora (nome e sigla), além dos resumos e palavras-chave. Em seguida organizou-se um arquivo com os documentos integrais dessas pesquisas, baixados nas respectivas bibliotecas digitais das instituições e/ou sites dos programas de pós-graduação, e, no caso de pesquisas não disponibilizadas eletronicamente, foram solicitadas ou providenciadas cópias xerox ou consultadas nas bibliotecas depositárias.

\footnotetext{
${ }^{10}$ SciELO - Scientific Electronic Library Online, disponível em < http://www.scielo.org/php/index.php>.
} 
Não se ateve aos extratos das pesquisas, tomados em uma primeira análise, mas sim a cada pesquisa em sua plenitude, tratada por meio da análise de conteúdo segundo os preceitos de Bardin (1995), que a define como

Um conjunto de técnicas de análise das comunicações visando obter, por procedimentos, sistemáticos e objetivos de descrição do conteúdo das mensagens, indicadores (quantitativos ou não) que permitam a inferência de conhecimentos relativos às condições da produção/recepção (variáveis inferidas) destas mensagens. (p. 42, gripo do autor)

Esta técnica é aplicada em três fases consecutivas: a pré-análise, na qual os documentos são selecionados e se define o corpus de análise; a codificação, quando os dados originais são então sistematizados e reunidos em unidades; e a inferência e interpretação, a partir da quantificação simples ou complexa dos dados.

As unidades constituem-se nas categorias de análise que podem ser definidas a priori ou a posteriori, sendo esta última a opção escolhida, uma vez que as categorias temáticas surgiram a partir da lógica de interpretação do pesquisador-autor desta tese, do objeto de estudo e da sua visão teórica, sendo as seguintes: distribuição espacial dos empreendimentos, recortes temáticos e fases evolutivas. Nesta última categoria, foram identificados quatro períodos configurados em quatro fases temporais do Turismo Rural Paulista no Cenário Brasileiro.

\subsection{Configuração da Produção Acadêmica}

\subsubsection{Características Gerais}

Como resultado foram localizadas 23 teses e dissertações que discutem algum aspecto da realidade do turismo rural no Estado de São Paulo, sendo 7 em nível de Doutorado e 16 em 
nível de Mestrado (Figura 4). Observa-se que o turismo rural em São Paulo foi abordado pela primeira vez em 1996, num estudo pioneiro que tinha como objeto de estudo as fazendas históricas na região de Ribeirão Preto (Dias, 1996).

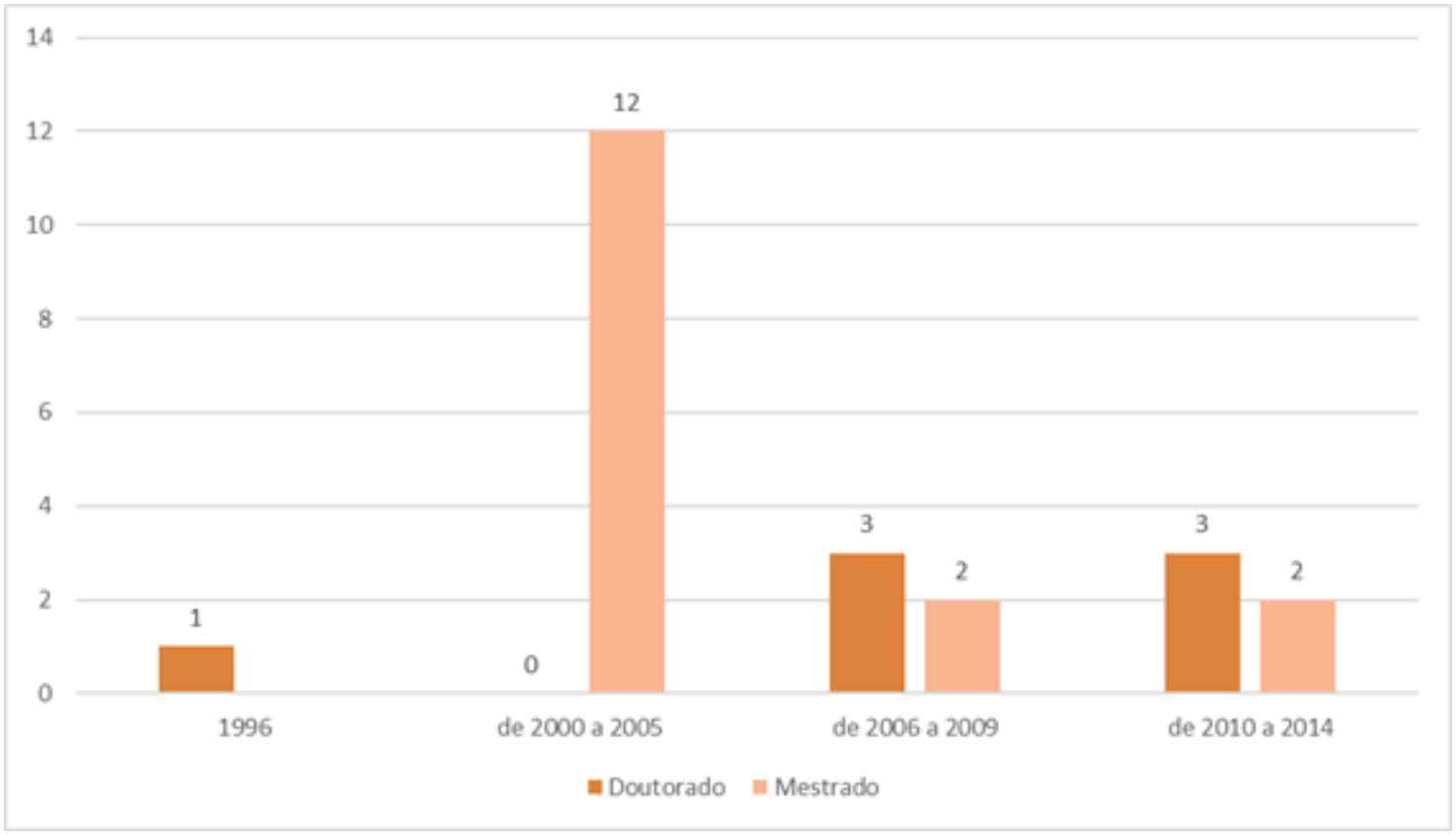

Figura 4 - Produção científica sobre turismo rural no estado de São Paulo, segundo nível de titulação no período de 1996-2014

Nota. Fonte: elaboração da autora (2016).

A temática reaparece somente em 2001, e no período de 2001 a 2005 verifica-se um incremento significativo desta produção, com estudos em nível de Mestrado. Nos períodos seguintes até 2014, a quantidade de estudos diminui para 5, de 2006 a 2009 e 5, de 2010 a 2014, mas com um aumento na quantidade de doutorados (6 no total). De certa forma este movimento acompanha o "movimento" da produção científica sobre o tema no cenário nacional. (Solha, 2012, p.169).

Observa-se que, apesar dos registros de implantação de negócios de turismo rural no estado terem se iniciado no final da década de 1980, o tema só desperta o interesse dos pesquisadores no início da década 2000, período em que estavam em elaboração as Diretrizes para o segmento do turismo, no âmbito federal (Figura 5). 


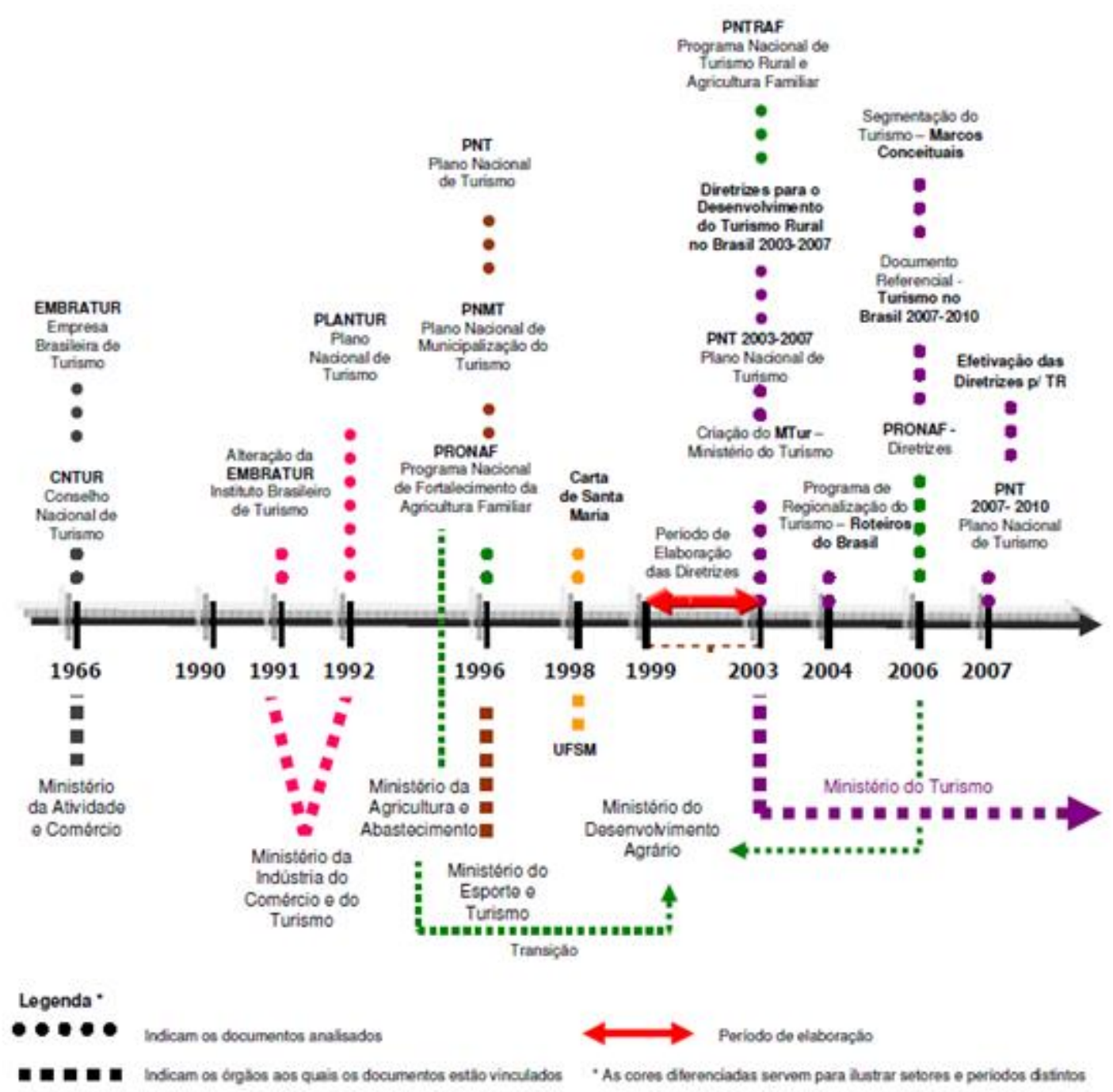

Figura 5 - Linha do Tempo das políticas públicas de turismo rural no Brasil

Nota. Fonte: Santos (2008, p. 71).

Além disso, as primeiras edições do Congresso Internacional de Turismo Rural e Desenvolvimento Sustentável (CITURDES), em 1998, na Universidade Federal de Santa Maria no Rio Grande do Sul, e do Congresso Brasileiro de Turismo Rural (CBTR), em 1999, organizado pela FEALQ - Fundação de Estudos Agrários Luiz de Queiroz, vinculada à ESALQ - Escola Superior de Agronomia Luiz de Queiroz, da Universidade de São Paulo, podem ter contribuído para promover uma maior visibilidade da temática junto aos 
pesquisadores e assim também fomentado o interesse pelo desenvolvimento de estudos na área.

Considerando as instituições produtoras (Figura 6), destaca-se a Universidade de São Paulo (USP), responsável por 9 estudos sobre o turismo rural no Estado, distribuídos entre os programas de pós-graduação de diferentes unidades: 6 da linha de pesquisa de Turismo e Lazer, do programa de Ciências da Comunicação da Escola de Comunicações e Artes (ECA), 2 do programa de Geografia, da Faculdade de Filosofia, Letras e Ciências Humanas (FFLCH) e 1 do programa de Ciências Ambientais (PROCAM).

A Universidade Paulista (UNESP), em seus diferentes campi, mas nos programas de Geografia, foi responsável por 4 estudos, seguida pela Universidade Federal de São Carlos (UFScar), com 3 estudos em diferentes programas de pós-graduação. A Universidade Estadual de Campinas (UNICAMP) por 3 estudos, e a Universidade do Vale do Paraíba (UNIVAP) por 2 estudos, além de 1 estudo da Universidade Federal de Santa Maria (UFSM) e da Universidade São Marcos.

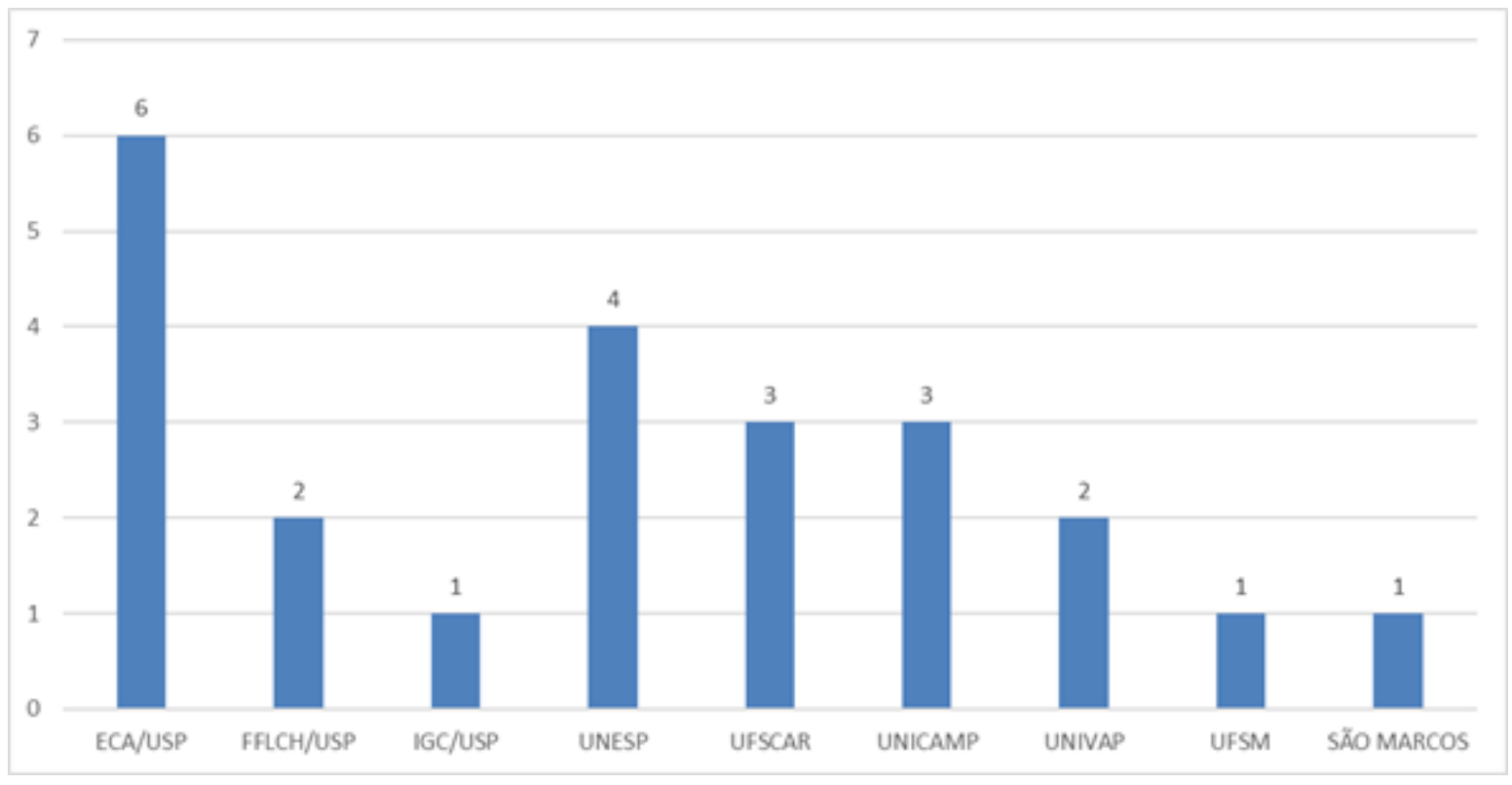

Figura 6 - Produção científica sobre turismo rural no estado de São Paulo segundo instituição produtora

Nota. Fonte: elaboração da autora (2016). 
A análise deste conjunto de estudos indica que o tema despertou interesse de diferentes áreas de conhecimento, com destaque para a produção na área de Turismo. Ao mesmo tempo percebeu-se uma singularidade: não foram encontrados estudos produzidos no âmbito de programas ligados a agricultura no Estado de São Paulo. Considerando que o fenômeno tem sido apontado com frequência em vários estudos acerca do setor agrícola no país, seja nos estudos de Silva (1996) ou mesmo nos últimos censos agropecuários do IBGE (2015), porque ainda não é tema de pesquisa nos programas de pós-graduação dedicados à questão agrícola?

Com esta característica se destaca somente a dissertação de Bovo (2004) defendida no programa de pós-graduação em Extensão Rural, da Universidade de Santa Maria, pioneira nos estudos sobre turismo rural no país. Tal situação pode ser reflexo das prioridades do setor agrícola no Estado de São Paulo, fortemente apoiado no agronegócio, e/ou da orientação das políticas públicas para o setor.

\subsubsection{Distribuição espacial dos empreendimentos}

As pesquisas acerca do turismo rural paulista têm como objeto de estudo em sua maioria, os empreendimentos de turismo rural. Assim, para identificar a distribuição espacial destes estudos, considerou-se os municípios em que estão localizados os empreendimentos. Como pode ser observar na Figura 7, os mesmos estão distribuídos em 45 municípios do Estado, com forte concentração nas cidades próximas à capital. Esta situação pode estar associada tanto ao volume expressivo de empreendimentos nesta região, quanto à proximidade da Universidade a qual os pesquisadores se vinculavam. 


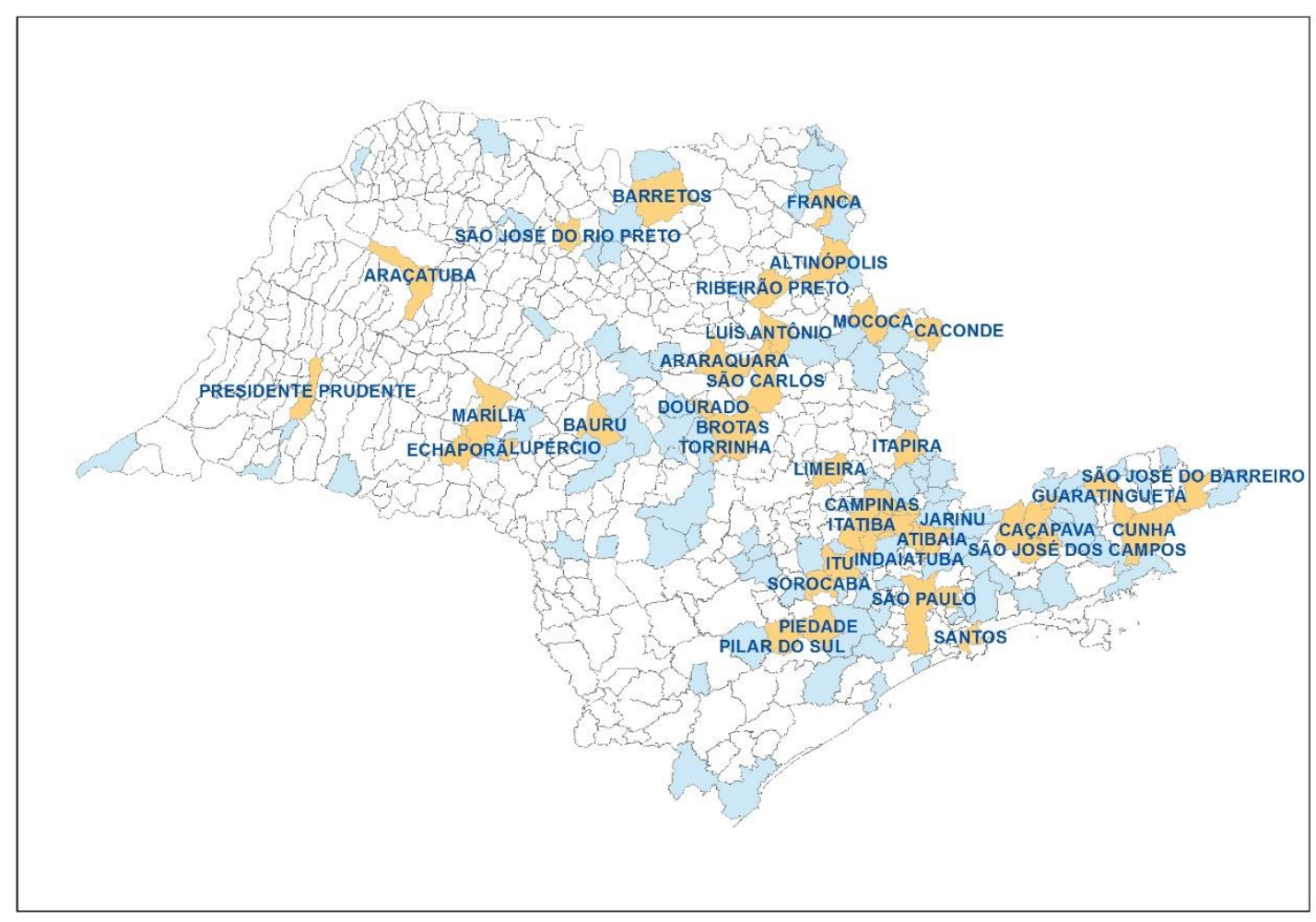

Figura 7 - Distribuição espacial dos estudos sobre turismo rural no estado de São Paulo

Nota. Fonte: elaboração da autora (2016).

Este número expressivo de municípios é decorrente das estratégias de análise propostas nestas investigações, que se apoiaram em sua maioria na observação da experiência de empreendimentos de turismo rural. Além disso os empreendimentos rurais estão distribuídos irregularmente pelo território (Oliveira, 2001).

Pode-se dividir os estudos em três grupos principais (Figura 8): aqueles que analisam uma única propriedade, configurando estudo de caso (2); aqueles que trabalham com duas propriedades (2) e aqueles que analisam mais de três propriedades (13). 


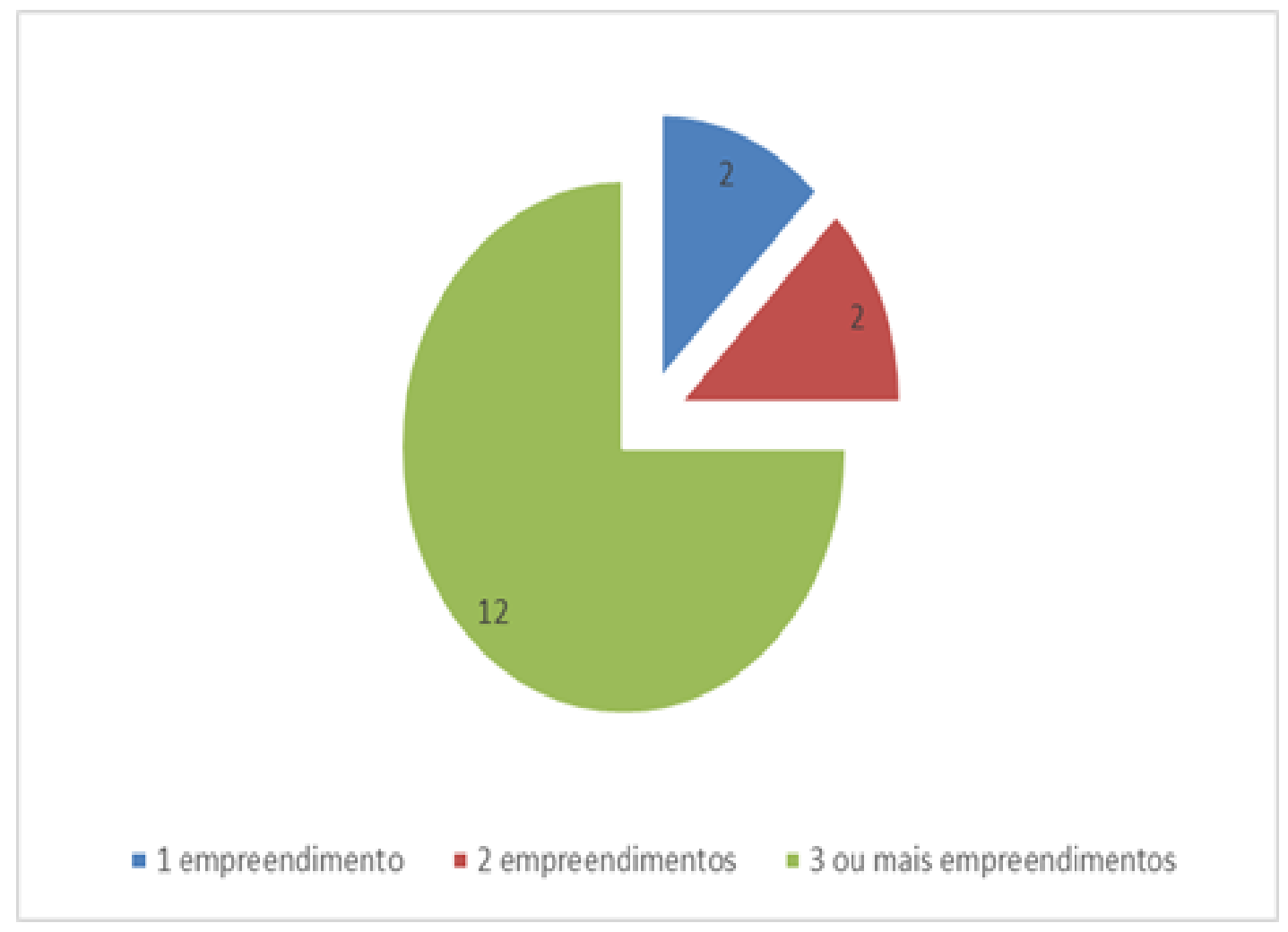

Figura 8 - Objeto dos estudos sobre turismo rural no estado de São Paulo

Nota. Fonte: elaboração da autora (2016).

Nesta última categoria as configurações são diversas. Há casos em que o objeto de estudo são os empreendimentos na Zona Rural de um município (5) ou empreendimentos localizados em diferentes municípios (8). Mas apenas dois destes estudos se propõe a analisar a organização dos empreendimentos em circuitos ou roteiros, e destacam a experiência do Circuito das Frutas (Figura 9), na Região Metropolitana de Campinas, constituído por 31 propriedades distribuídas em 8 municípios. (Gonçalves, 2004, p. 105) 


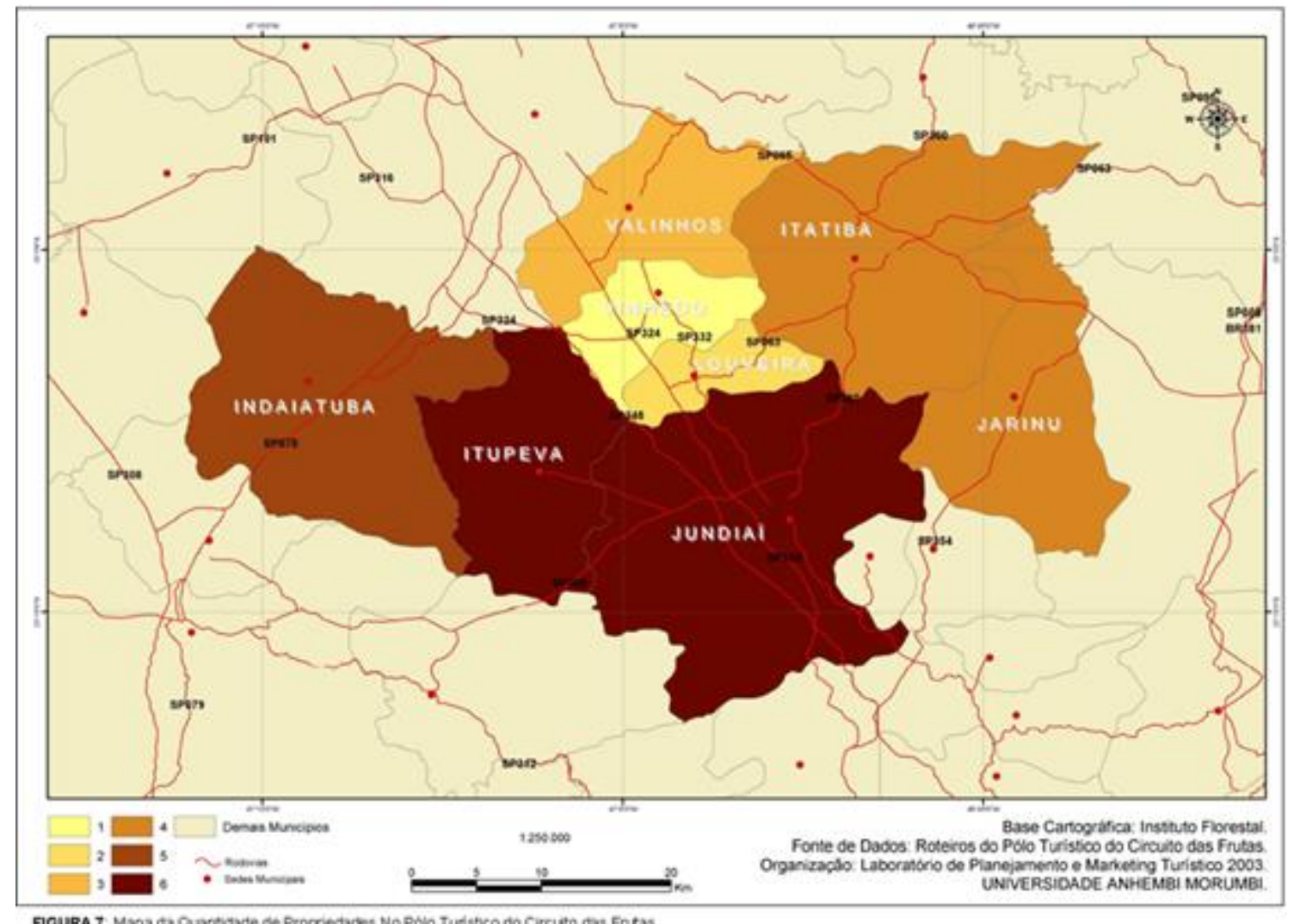

Figura 9 - Mapa da quantidade de propriedades no Pólo Turístico do Circuito das Frutas

Nota. Fonte: Gonçalves (2004, p.106).

Por outro lado Oliveira (2001) se propõe a trabalhar com uma perspectiva mais abrangente selecionando 29 empreendimentos de turismo rural, sendo 27 em São Paulo e dois em Minas Gerais. Enquanto Bovo (2004) que se propõe a mapear os empreendimentos de turismo rural que estão vinculados às associações de turismo rural, construindo um banco de dados a partir das informações obtidas em várias fontes, principalmente as associações de turismo rural, identificando mais de 240 empreendimentos no período (Figura 10). 


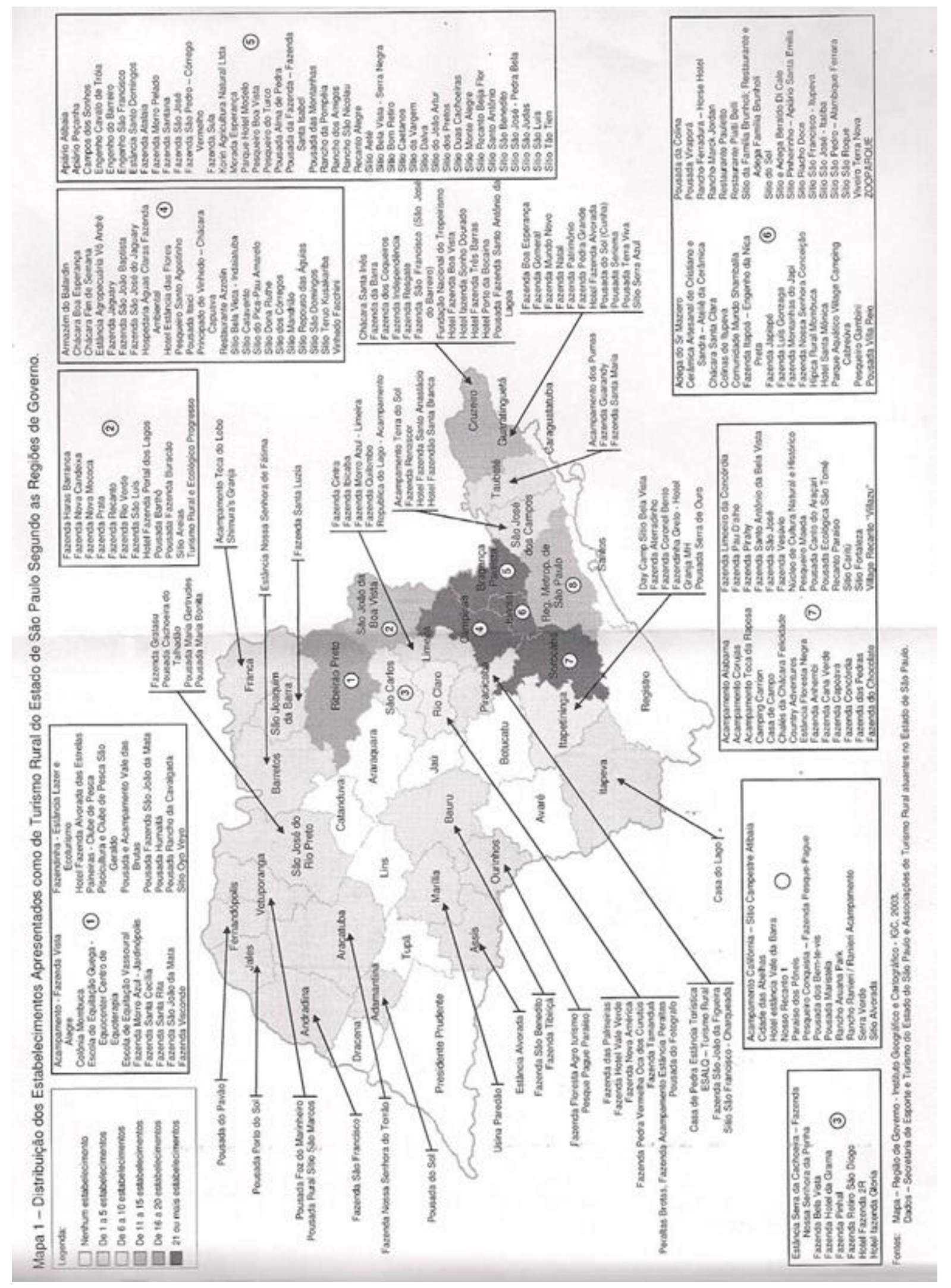

Figura 10 - Empreendimentos de turismo rural no Estado de São Paulo

Nota. Fonte: Bovo (2004). 
Ao verificar uma maior concentração destas propriedades próximas a grandes polos regionais salienta que este fator juntamente com a proporcionalidade entre número de estabelecimentos e dimensão populacional da região administrativa,

[...] é um indicativo de que a proximidade dos pólos econômicos regionais facilita e estimula a estruturação da atividade turística em estabelecimentos rurais porque existe um grande mercado consumidor nestas localidades, dada a existência de uma grande concentração demográfica e a possibilidade destas pessoas realizarem viagens de curta duração, principalmente aos fins de semana, o que seria inviabilizado por uma distância muito grande. (Bovo, 2004, p. 61)

Esta distribuição espacial dos empreendimentos de turismo rural no Estado também foi observada por Oliveira (2001), ao salientar que esta também se deve às "características históricas, pois, como já foi citado, os insumos histórico-culturais têm grande importância na formatação do produto turístico rural, e essas regiões guardam importantes marcos dos movimentos Bandeirante e do Ciclo do Café" (pp. 51-52).

Embora a investigação de Pinho (2014) se dedique a analisar a atuação dos extensionistas da CATI - Coordenadoria de Assistência Técnica Integral do Estado de São Paulo, junto as Unidades Produtivas Rurais (UPR) em todo o Estado, traz uma valiosa contribuição ao indicar a possibilidade de se contar com fontes de dados específicas do setor agropecuário para pesquisas sobre turismo rural.

Neste caso em especial, analisa a indicação do turismo rural como atividade prioritária nos "Planos Municipais de Desenvolvimento Rural Sustentável (2010-2013)", identificando 43 municípios no Estado. Em seguida, faz uma comparação com a lista de municípios indicada no "Guia de Turismo Rural do Estado de São Paulo" (Roque, 2006) e chega a um universo 
de 87 municípios (Figura 11), destacando que 92\% destes municípios fazem parte de algum roteiro ou circuito turístico do Estado (Pinho, 2014, p.33).

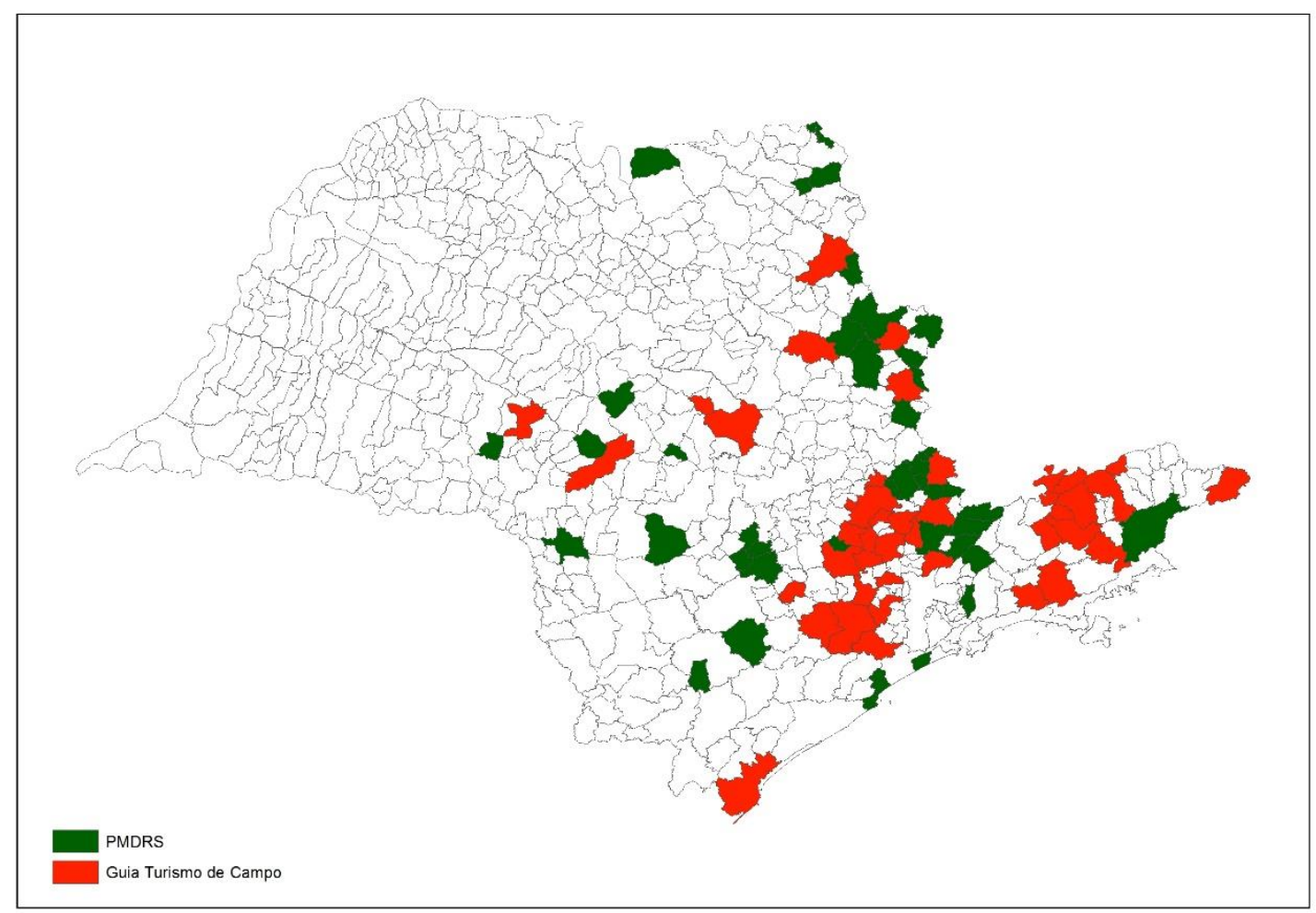

Figura 11 - Municípios com atividade de turismo rural

Nota. Fonte:Elaboração a autora com base em Pinho (2014)

Como primeiro resultado observa-se que os estudos conseguem abranger apenas $49 \%$ dos municípios paulistas que contam com o turismo rural como atividade forte, se considerar o conjunto identificado por Pinho (2014). As estratégias utilizadas nestes estudos para identificar os empreendimentos de turismo rural no Estado foram muito heterogêneas, e muitas delas não foram definidas a partir de um mesmo conceito de turismo rural, além de terem sido realizadas em períodos diferentes.

Certamente tal tentativa de mapeamento não é uma representação fiel da realidade, mas traz uma contribuição importante na medida em que provoca a reflexão acerca do que deveria 
ser considerado turismo rural e, principalmente, elaborando e aplicando critérios e classificações que podem contribuir para futuros estudos. Como por exemplo, tem-se a proposta de Oliveira (2001) para classificar os empreendimentos em função do contexto que os motivou a procurar o turismo rural como uma opção de atividade econômica para sua propriedade rural, na qual identifica três tipos e seus atributos:

1. Autentico - é produtor rural e reside na propriedade;

2. Sazonal - quando a propriedade rural é a segunda residência;

3. Investidor - sem vínculos com o meio rural.

Sob outra ótica Geraldo (2012, p. 89) ao analisar as experiências na região do Pólo Cuesta propõe uma tipologia a partir das principais atividades praticadas e/ou estruturas dos empreendimentos analisados, identificando 6 (seis) categorias de empreendimentos:

\section{Hospedagem no espaço rural com padrão contemporâneo:}

- Subtipo 1: com atributos histórico-arquitetônicos relevantes;

- Subtipo 2: com atributos histórico-arquitetônicos pouco relevantes.

\section{Hospedagem no espaço rural com padrão tradicional.}

\section{Resort no espaço rural com padrão contemporâneo.}

\section{Resort no espaço rural em fazenda histórica:}

- Subtipo 1: com atributos histórico-arquitetônicos relevantes;

- Subtipo 2: com atributos histórico-arquitetônicos pouco relevantes.

\section{Turismo cultural no espaço rural:}

- Subtipo 1: sem equipamentos de lazer e aventura; 
- Subtipo 2: com equipamentos de lazer e aventura.

\section{Turismo de esportes e aventura no espaço rural.}

Estes são apenas alguns exemplos de como a heterogeneidade dos empreendimentos turismo rural juntamente com a multiplicidade de conceitos existentes podem comprometer as tentativas de mensuração, mapeamento ou compreensão do segmento em sua totalidade, mesmo com recortes espaciais. Tanto que os diferentes estudos que se propuseram a analisar a temática e caracterizar as propriedades no Estado se depararam com este obstáculo, e assim cada pesquisador elaborou uma estratégia diferente para entender esta realidade e os resultados são os mais diversos e pouco conclusivos.

Mas então como superar este impasse? Com certeza compreendendo os fatores que levam aos investigadores do tema a se apoiar em distintas abordagens. Neste sentido, Tulik (2010), ao refletir acerca da questão das abordagens conceituais e das tipologias, apontou alguns elementos que colaborariam para conformar esta situação:

- ... a diversidade de abordagens pode estar na formação acadêmica do pesquisador,

- a lenta assimilação de novos paradigmas, que pode explicar a permanência de certo elementos conceituais,

- pesquisadores de outras áreas estudando o turismo e portanto utilizando o conceito de sua área de origem, o que dificulta a concepção científica inteiramente homogênea.

- Além das diferenças quanto ao entendimento do que é o rural ....

A isso se acrescenta a pouca concordância com o conceito de turismo rural definido oficialmente pelo Ministério do Turismo, após uma série de encontros entre especialistas, profissionais e acadêmicos, e expresso como: "O conjunto de atividades turísticas 
desenvolvidas no meio rural, comprometido com a produção agropecuária, agregando valora produtos e serviços, resgatando e promovendo o patrimônio cultural e natural da comunidade" (MINTUR, 2008, p. 19).

A questão dos conceitos, amplamente discutida por Tulik (2010), parece ser fator fundamental a ser resolvido para que se possa avançar na compreensão do segmento, e principalmente apoiar a geração de dados e informações sistemáticas e de qualidade, seja para mensurar ou mesmo elaborar políticas públicas adequadas e eficazes.

Neste sentido, o turismo no espaço rural começa a emergir nos estudos que tratam especificamente da realidade rural brasileira. Dentre eles os estudos de Silva et al. (1996) acerca do rural paulista, na década de 1990, que já identificavam novas funções e "novos" tipos de ocupação do meio rural, entre as quais estava "propiciar lazer aos paulistanos nos feriados e fins de semana através do pesquisa pague, hotéis-fazenda e chácaras de fins de semana” (p. 72). Recentemente, o IBGE, no Projeto Regiões Rurais, constatou que

$\mathrm{Na}$ análise da pluriatividade constituiu uma realidade cada vez mais presente no campo, aí se destacando novas atividades relacionadas com o lazer, com o turismo ecológico e rural e com outras modalidades de uso não agrícola do espaço rural, além de uma diversidade de novas atividades relacionadas com jardinagem, haras, etc. (Silva, 2014, p.243).

Isto pode ser um indicador de que a presença cada vez mais destacada das atividades de lazer e do turismo no universo rural brasileiro impulsione a busca por uma abordagem interdisciplinar da temática e com uma maior aceitação dos pesquisadores das diferentes áreas de conhecimento que têm se dedicado ao assunto.

E de fato, podem trazer um aporte significativo aos estudos da área, na medida em que tem conhecimento sobre fontes de dados, discussões e políticas do setor agrícola que estão incorporando a discussão da atividade de turismo no campo. Como por exemplo, o estudo 
de Pinho (2014), que elabora uma estratégia de identificação dos municípios do Estado que tem o turismo rural como uma de suas atividades econômicas de destaque nos Planos Municipais de Desenvolvimento Rural Sustentável (PMDRS).

\subsubsection{Recortes temáticos}

Além de traçar um panorama da produção acadêmica do turismo rural no Estado de São Paulo, também se pretendia obter elementos, dados e informações que permitissem compreender a percepção dos investigadores acerca deste segmento. Desta forma, optou-se por analisar os recortes temáticos das teses e dissertações, a partir de sua vinculação com questões mais gerais do turismo rural no país.

Como pano de fundo estão os estudos de Solha e Rejowski (2013), que trata das interfaces entre a produção científica e o desenvolvimento do segmento no país, Solha (2012), que aborda o turismo rural como objeto de estudo na produção acadêmica brasileira, e de Lane (2014) que reflete sobre as mudanças e as perspectivas para o turismo rural, a partir da realidade europeia.

Ao se comparar os objetivos da produção científica sobre turismo rural em São Paulo em relação ao quadro geral do país ressalta-se o interesse por algumas questões em especial, com pouca correspondência com as prioridades percebidas no âmbito nacional, conforme a Tabela 3. Convém citar que essa tabela traz dados de universos temporais um pouco diferentes, o nacional de 1996 a 2011 e o de São Paulo, de 1996 a 2015. 
Tabela 3 - Produção científica segundo objetivos da pesquisa

\begin{tabular}{|c|c|c|c|c|}
\hline \multirow{2}{*}{ Objetivos } & \multicolumn{2}{|c|}{ Brasil } & \multicolumn{2}{|c|}{ São Paulo } \\
\hline & Qtde & $\%$ & Qtde & $\%$ \\
\hline $\begin{array}{l}\text { Caracteriza/descreve o turismo rural em uma } \\
\text { região/propriedade/localidade }\end{array}$ & 38 & 21,23 & 2 & 9,09 \\
\hline $\begin{array}{c}\text { Identifica transformações provocadas pelo } \\
\text { turismo rural }\end{array}$ & 24 & 13,41 & -- & -- \\
\hline Realiza estudo de viabilidade & 22 & 12,29 & 2 & 9,09 \\
\hline Analisa a influência das políticas públicas & 10 & 5,59 & -- & -- \\
\hline $\begin{array}{c}\text { Realiza diagnóstico do turismo rural em uma } \\
\text { região/localidade }\end{array}$ & 9 & 5,03 & 3 & 13,64 \\
\hline Analisa sustentabilidade em empreendimentos & 8 & 4,47 & 1 & 4,55 \\
\hline Analisa arranjos colaborativos & 7 & 3,91 & 1 & 4,55 \\
\hline $\begin{array}{c}\text { Analisa as relações do turismo rural no espaço } \\
\text { rural }\end{array}$ & 6 & 3,35 & 5 & 22,73 \\
\hline $\begin{array}{c}\text { Analisa interfaces entre patrimônio histórico } \\
\text { cultura e turismo rural }\end{array}$ & 6 & 3,35 & 1 & 4,55 \\
\hline $\begin{array}{c}\text { Analisa/desenvolve processos de gestão } \\
\text { ambiental em empreendimentos }\end{array}$ & 6 & 3,35 & -- & -- \\
\hline Realiza inventário do turismo rural & 6 & 3,35 & -- & -- \\
\hline $\begin{array}{c}\text { Analisa a relação entre turismo rural e } \\
\text { desenvolvimento }\end{array}$ & 5 & 2,79 & -- & --- \\
\hline Analisa processos de gestão & 4 & 2,23 & 1 & 4,55 \\
\hline Analisa estratégias de marketing & 3 & 1,68 & -- & -- \\
\hline $\begin{array}{c}\text { Analisa estratégias de qualificação de recursos } \\
\text { humanos }\end{array}$ & 3 & 1,68 & -- & -- \\
\hline Analisa os resultados de programas/projetos & 3 & 1,68 & -- & -- \\
\hline Identifica percepções do turista & 3 & 1,68 & 3 & 13,64 \\
\hline Discute aspectos epistemológicos & 2 & 1,12 & 1 & 4,55 \\
\hline Discute o papel da mulher & 2 & 1,12 & -- & -- \\
\hline Discute o processo de comunicação & 2 & 1,12 & -- & -- \\
\hline Identifica percepções dos proprietários rurais & 2 & 1,12 & -- & -- \\
\hline Identifica tendências & 2 & 1,12 & -- & -- \\
\hline Informação não localizada & 6 & 3,35 & -- & -- \\
\hline
\end{tabular}




\begin{tabular}{|c|c|c|c|c|}
\hline Outros & -- & -- & 2 & 9,09 \\
\hline Total & 179 & 100,00 & 22 & 100 \\
\hline
\end{tabular}

Nota. Fonte: elaboração da autora, com base nos dados de Solha (2012).

Observa-se que os estudos que analisam as transformações provocadas pelo desenvolvimento do turismo rural representam 13,41\%, assim como as relações do turismo rural com o espaço rural (3,35\%) De modo geral estas pesquisas se preocupam em verificar as mudanças econômicas, sociais e espaciais decorrentes da implementação do turismo rural em propriedades e localidades, principalmente nas áreas em que a atividade é mais antiga, como em Santa Catarina, São Paulo, Paraná e Rio Grande do Sul. Contudo isto não corresponde à realidade observada nos estudos sobre o turismo rural paulista, que ressaltam uma forte preocupação com o estudo das relações do turismo rural com o espaço rural $(22,73 \%)$, ou seja, com a dinâmica e não com os impactos.

Os trabalhos que têm como objetivo a realização de estudos de viabilidade (12,29\%), junto com diagnóstico (5,0\%) e inventário (3,35\%), representam 20,64\% do conjunto de pesquisas. De certa forma, também podem ser compreendidos como estudos exploratórios que permitem um levantamento inicial de informações. Estas variáveis são ressaltadas também nos estudos paulistas, mas com prioridades diferentes: o diagnóstico do turismo rural em uma região ou localidade $(13,64 \%)$ é mais frequente que os estudos de viabilidade $(9,09 \%)$, não existindo registro de inventários.

No conjunto das teses e dissertações sobre a temática observa-se uma quantidade expressiva de estudos que caracterizam ou descrevem o turismo rural, seja em propriedades, em localidades ou região $(21,23 \%)$, o que pode estar relacionado ao fato de que maioria das pesquisas foi realizada em nível de mestrado, e também pela necessidade de estudos exploratórios que pudessem contribuir à compreensão do contexto em que o turismo rural 
está se desenvolvendo. Contudo tal situação não se reflete nos estudos de São Paulo, com apenas 9,09\% dos estudos trabalhando com esta questão.

De modo geral, se verificam poucos estudos acerca das percepções do turista $(1,68 \%)$, pois a produção se concentra na caracterização da oferta e na análise dos impactos provocados pelo Turismo Rural. Entretanto os estudos sobre São Paulo indicam uma maior sensibilidade a esta questão $(13,64 \%)$.

Por outro lado, verificam-se estudos com objetivos diferenciados no que se refere ao tratamento de questões ambientais, seja analisando a sustentabilidade de empreendimentos (4,47\%), seja desenvolvendo processos de gestão ambiental específicos para o segmento (3,35\%). Este interesse não foi verificado nas investigações sobre o turismo rural paulista, entre as quais apenas um estudo se propõe a mensurar a sustentabilidade dos empreendimentos $(4,55 \%)$.

A discussão sobre políticas públicas para o segmento é um tema sempre presente nos eventos técnico-científicos e comerciais, e também relevante como objetivo de pesquisa $(5,59 \%)$, assim como a análise de resultados da implementação de programas e projetos (1,68\%). Curiosamente não se verificou nenhuma investigação que apresentasse como objetivo principal uma discussão sobre políticas públicas ou mesmo avaliação de programas e projetos, embora este tema permeie os debates sobre a questão do turismo rural no Estado, da mesma forma, a temática do desenvolvimento do segmento que aparece nos estudos brasileiros $(2,79 \%)$ não foi indicada nos estudos sobre o Estado, mas a discussão acerca dos arranjos colaborativos aparece com um único estudo (4,55\%).

Já os estudos acerca da dinâmica e funcionamento das propriedades que atuam com turismo rural ainda são pouco representativos, se considerar a importância com que essa temática tem sido tratada nos eventos e nas diretrizes de desenvolvimento para a área. Estes estudos podem ser divididos em análise de processos de gestão (2,23\%), análise de estratégias de 
marketing $(1,68 \%)$, estratégias de qualificação de recursos humanos $(1,68 \%)$ e processos de comunicação $(1,12 \%)$. Novamente a situação se assemelha ao que foi percebido no âmbito nacional, apenas um estudo sobre os processos de gestão dos empreendimentos (4,55\%).

A questão de terminologia e definição que ainda parece não ter sido resolvida, e que surge nos vários documentos que analisam o turismo rural no mundo e no país, não instigou muitos pesquisadores a se dedicarem com profundidade a tais questões epistemológicas, tratadas apenas em apenas 2 estudos com foco no Brasil (1,12\%), e em 1 em São Paulo.

Além das questões apresentadas acima, também são indicados como objetivos de pesquisa a discussão sobre o papel da mulher no turismo rural (1,12\%), as percepções de proprietários $(1,12 \%)$ e dos turistas (1,68\%), e a verificação de tendências de desenvolvimento do segmento $(1,12 \%)$. Apesar de nenhum destes objetivos ter sido identificado nos estudos sobre São Paulo, ressaltam-se duas abordagens inovadoras, uma que trata da questão da hospitalidade rural e outra sobre o papel dos extensionistas no segmento.

A identificação dos objetivos de pesquisa e a comparação entre a realidade nacional e a estadual contribuem para perceber divergências e semelhanças entre os interesses de pesquisa. Todavia estas escolhas são resultado da combinação de uma série de fatores, o que levou à necessidade de compreender estas interfaces, perante o que se realiza uma análise temporal que considerou o contexto do turismo rural no país e no exterior neste período.

\subsection{Turismo Rural Paulista no Cenário Brasileiro}

Para analisar as transformações ocorridas no turismo rural brasileiro Solha e Rejowski (2013) consideraram três períodos de tempo, de 1984 a 2012, em função das características comuns 
e das mudanças significativas na percepção e no avanço do conhecimento sobre a temática.

Neste estudo optou-se por utilizar a mesma estratégia de análise, ampliando o período até 2016, e analisando a situação geral do período mais recente, a partir dos questionamentos propostos por Lane (2014), o que levou à configuração de quatro fases temporais:

- De 1984 a 2000 - das primeiras iniciativas à necessidade de qualificação dos produtos e serviços;

- De 2001 a 2005 - dos desafios da implementação à organização do segmento;

- De 2006 a 2010 - da necessidade de ordenamento à competitividade;

- De 2011 a 2016 - a caminho da segunda geração do turismo rural.

\subsubsection{Das primeiras iniciativas à necessidade de qualificação dos produtos e serviços} (1984 a 2000)

O turismo rural no país guarda muitas similaridades com aquele ocorrido na Europa, como aponta Tulik (2010), não só na perspectiva acadêmica e conceitual, mas também pelas características do processo de formação e de suas origens. Lane, ao descrever a experiência europeia, explica que o turismo rural "originou-se de vários pequenos agricultores e empreendedores rurais interessados em 'sobreviver' face aos retornos decrescentes das agricultura e outras pequenas empresas rurais" (2014, p. 18); embora, em um momento posterior, o movimento do turismo rural no país responde a demandas semelhantes a dos produtores rurais europeus.

Os registros sobre os primeiros empreendimentos de turismo rural datam de meados da década de 1980, observando uma expansão gradual que é percebida com maior nitidez a partir de meados da década seguinte. Nesta década os estudos de turismo de um modo geral 
estavam impregnados da discussão global sobre desenvolvimento sustentável, incrementada pela realização da ECO-92, no Rio de Janeiro.

Assim, além das questões próprias que o segmento já apresentava, se adicionava a forte preocupação com a sustentabilidade dos seus empreendimentos, a qual se refletiu nas políticas públicas com a publicação da primeira versão do Manual Operacional de Turismo Rural (EMBRATUR, 1994), na academia com a realização do primeiro encontro do CITURDES - Congresso Internacional sobre Turismo Rural e Desenvolvimento Sustentável, em 1998, e a divulgação da Carta de Santa Maria, e em seguida com a primeira edição do CBTR - Congresso Brasileiro de Turismo Rural, em 1999.

De certa forma este período caracterizou-se por um grande otimismo em relação ao desenvolvimento do turismo rural, tanto no país e quanto no exterior, como ressalta Lane (2014):

[...] nos anos de 1980 e nos anos de 1990, muitos especialistas e apoiadores acreditavam que o turismo rural traria importantes ganhos sociais, econômicos e de preservação. Preencheria os requisitos dos três pilares da sustentabilidade: social, ambiental e econômico. Geraria empregos locais e renda, auxiliaria no aumento da clientela para lojas de varejo rural, para transporte público e acomodações, restaurante e bares... Motivaria e pagaria a conservação e preservação de prédios históricos, paisagens e tradição, contribuiria para a administração de áreas protegidas. (p. 27)

Estas tantas esperanças num único segmento parecem ser decorrentes da percepção de que o turismo rural seria um instrumento de regeneração rural e não parte do desenvolvimento do turismo. Lane (2014) traz um relato bastante revelador desta perspectiva, nos primórdios de 1990, quando a OECD - Organização para Cooperação e Desenvolvimento Econômico, numa iniciativa de seu secretariado de desenvolvimento rural, convida os secretários do setor agrícola e do turismo para observar os debates acerca do turismo rural, e assinala que ambos 
"viam o turismo rural como uma ameaça ao "status quo", ou como uma distração de suas atividades principais" (p. 20).

Contudo, a criação da Câmara Setorial de Lazer e Turismo no Meio Rural, na Secretaria de Agricultura do Estado de São Paulo, indica o interesse do poder público estadual pelo tema (São Paulo, 1998). Apesar de ser um período de iniciativas relevantes por parte de empreendedores, de políticas públicas e de encontros científicos, isto parece não ter se refletido rapidamente no volume de produção acadêmica sobre o tema, que "apresentava ainda poucos estudos pioneiros na área, caracterizando-se como um período de prospecção" (Solha, 2012, p.169). Observa-se que a discussão acerca deste segmento no Estado de São Paulo foi tema de um único doutorado, que realizou um estudo de viabilidade para o uso das fazendas de café na Região de Ribeirão Preto, se apoiando na experiência francesa (Dias, 1996).

Por outro lado, foi no final desse período e início do próximo que foram publicadas algumas obras tornadas posteriormente referenciais a pesquisadores brasileiros que precisaram de um aporte conceitual para desenvolver seus estudos. É nesse contexto que se destacam as várias obras produzidas por três pesquisadores brasileiros o Prof. Dr. Joaquim Anécio de Almeida, da Universidade Federal de Santa Maria, a Profa. Dra. Adyr Rodrigues do curso de Geografia e a Profa.Dra. Olga Tulik do curso de Turismo, ambas da Universidade de São Paulo - que foram e ainda são referências na maior parte dos estudos de turismo rural no país. Além de textos essenciais também se sobressaem as obras publicadas com as principais discussões ocorridas a cada edição do CITURDES - Congresso Internacional de Turismo Rural e Desenvolvimento Sustentável.

A academia não costuma responder rapidamente aos estímulos, talvez pelo tempo que é necessário para a observação sistemática do fenômeno, e também face às condições adequadas para coleta e tratamento de dados. Mas está sempre atenta, aos eventos científicos 
e comerciais, pois costumam ser importantes canais de comunicação para os investigadores da área compartilharem os resultados de seus estudos e estimularem o interesse de novos pesquisadores pela temática (Solha, 2012, p. 169).

\subsubsection{Dos desafios da implementação à organização do segmento (2001-2005)}

A visibilidade que a temática adquiriu no período anterior, em função dos eventos científicos, da elaboração de diretrizes nacionais para o segmento e do incremento nos negócios de turismo rural, certamente contribuíram para provocar e incentivar os pesquisadores a se dedicarem ao tema, pois a produção acadêmica sobre o assunto cresce exponencialmente, de 7 para 82 estudos num período de 5 (cinco) anos, sendo 80 em nível de Mestrado e dois de Doutorado (Solha, 2012, p.169).

Nos eventos da área persistiam temas ligados à estruturação e funcionamento dos empreendimentos juntamente com temáticas recorrentes à sustentabilidade e ao cooperativismo. No âmbito do turismo ocorre uma profunda alteração na política nacional, tanto nas estruturas com a criação do Ministério do Turismo, nas estratégias que passam a considerar desenvolvimento regional ao invés do municipal, e na construção de um maior diálogo com outras áreas. Assim a discussão do turismo rural ganha força e novas abordagens com a parceria estabelecida com o Ministério do Desenvolvimento Agrário, que entende o turismo rural associado diretamente à agricultura familiar. (Solha \& Rejowski, 2013)

Enquanto os empreendedores começam a se organizar criando associações de cunho local, regional e nacional, e realizando eventos técnico-comerciais, entendem que a profissionalização é imprescindível e começam a planejar de modo mais sistemático sua própria evolução. Neste cenário se destacam as temáticas sobre meio ambiente, 
sustentabilidade, inclusão social e a questão de gênero (Solha, 2012). A primeira tentativa de mapeamento dos empreendimentos rurais do Estado de São Paulo gera uma publicação da Editora Turismo de Campo com o Ministério do Turismo, o "Turismo Rural Brasileiro Região sudeste" (Roque, 2004).

Esta mesma situação se verifica nos estudos sobre turismo rural em São Paulo, que teve um grande impulso com 12 (doze) estudos de Mestrado no período, em cujos objetivos se destacam o interesse em analisar as relações do turismo rural no espaço rural, a partir de diferentes perspectivas e recortes, como os citados a seguir.

Dale (2001) analisa a presença do turismo rural no bairro de Gomeral, em Guaratinguetá, São Paulo, e observa que o seu desenvolvimento não corresponde a um desenvolvimento setorial, ou seja, não é um desenvolvimento turístico". Embora verifique que o turismo não tem papel fundamental neste processo, destaca que o mesmo é influenciado pela capacidade da população local em organizar a oferta de produtos e serviços diante das pressões de uma demanda turística. Assim sugere que o planejamento turístico de regiões com estas características deve considerar o envolvimento de outros segmentos além daqueles que atuam diretamente na atividade turística.

Ribeiro (2002) se apoia numa leitura positiva dos resultados que podem advir da implementação do turismo rural no Núcleo Guaramirim, no município de Piedade. Considera que um planejamento cuidadoso pode contribuir para gerar mudanças favoráveis para a área rural objeto do estudo. Com esta mesma leitura acerca dos impactos positivos que podem ser gerados pelo turismo, Viegas (2005), verifica a possibilidade do turismo rural gerar renda e contribuir com a preservação ambiental da região de Parelheiros, São Paulo, a partir da perspectiva dos proprietários de residência secundária e dos empreendimentos turísticos. 
Costa (2001) realiza um diagnóstico do turismo no município de Monteiro Lobato, destacando as transformações na paisagem e nas atividades das propriedades rurais que se reorganizam para atender a uma crescente demanda de lazer e turismo, apontando para a necessidade de elaboração um plano de desenvolvimento para o local ${ }^{11}$. Da mesma forma Pinto (2005) propõe uma estratégia para difundir informações qualificadas que podem apoiar a elaboração de um plano de desenvolvimento turístico apoiado no turismo rural para o município de Echaporã, tendo como referência a experiência de turismo rural de Venda Nova do Imigrante (Espírito Santo).

Gonçalves (2004) realiza o diagnóstico do Circuito Turístico das Frutas, a partir de uma perspectiva operacional, na qual considera a efetividade comercial desta proposta. Para tanto desenvolve estratégias interessantes para categorizar e analisar a experiência de turismo rural ofertada nos diversos municípios que compõem o Circuito, identificando os elementos e a organização que juntos configuram este produto turístico. Observa-se que este estudo se distingue pela abordagem e pelo cuidadoso trabalho de mapeamento e análise da realidade.

Se por um lado verifica-se um empenho dos investigadores em realizar diagnósticos da oferta de produtos e serviços de turismo rural, por outro manifesta-se a inquietude acerca do perfil do turista deste segmento, que é explorada na investigação de Felice (2002) e Cunha (2004). Enquanto a primeira entende que o turismo rural direcionado ao público da terceira idade pode contribuir para a regeneração de áreas rurais, a segunda examina as interfaces entre os turistas e o patrimônio em ambientes rurais.

Bovo (2004) apresenta o único estudo que tem como objetivo principal traçar um panorama do turismo rural no Estado de São Paulo, e para tanto se apoia em informações obtidas de diferentes fontes, das quais se sobressaem as associações de turismo rural atuantes no

\footnotetext{
11 Esta situação foi verificada no diagnóstico do Plano de Desenvolvimento Municipal de Turismo, elaborado em 2014, para o município pelo curso de Turismo da Escola de Comunicações e Artes (ECA, 2014).
} 
período. A partir delas consegue preparar um banco de dados com a identificação de mais de 240 empreendimentos de turismo rural em todo o Estado, e além disso registra a percepção dos seus responsáveis neste momento do desenvolvimento do turismo rural paulista, portanto trazendo uma contribuição relevante.

Para examinar os problemas e as necessidades dos proprietários rurais interessados em desenvolver o turismo rural, Oliveira (2001) também realiza um levantamento de empreendimentos rurais no Estado, selecionando um conjunto relevante de experiências distribuídas no território. Assim, além de contribuir para a melhor compreensão dos processos de gestão deste negócio, também oferece um cenário dos empreendimentos.

A gestão de negócios de turismo rural está fortemente atrelada à questões de sustentabilidade, no que tange ao incremento de melhorias ao meio ambiente, promoção da inclusão social, valorização da cultura local e geração de receitas e novos postos de trabalhos. Tais indicadores são averiguados por Esteves (2004) em um pequeno conjunto de empreendimentos de turismo rural, que conclui ser a atividade promotora de ganhos na sustentabilidade das unidades produtivas após sua implantação. Por último, a problemática dos conceitos de turismo rural é o foco do trabalho de Ishiy (2002), que a partir de um estudo de caso discute a relação entre o conceito e a realidade dos empreendimentos.

Os estudos demonstram, de modo geral, um forte otimismo com a implantação da atividade turística no espaço rural, associado principalmente às expectativas dos efeitos positivos que carrega consigo. Assim dimensionar, caracterizar e compreender o fenômeno que está em desenvolvimento é a tônica destes trabalhos no universo paulista. 


\subsubsection{Da necessidade de ordenamento à competitividade (2006 a 2010)}

A expansão e a diversificação dos empreendimentos de turismo rural no país reforçam a necessidade de políticas públicas específicas para o segmento, e como resultado elaboram-se as Diretrizes para o Desenvolvimento do Turismo Rural (MINTUR, 2008) que

[...] têm por base a valorização da ruralidade, a conservação do meio ambiente, os aspectos socioeconômicos do setor, com destaque para a agricultura familiar e a articulação interinstitucional e intersetorial, definindo algumas ações norteadoras para o envolvimento do poder público, iniciativa privada, organizações não-governamentais $\mathrm{e}$ comunidades. (p.5)

Os eventos comerciais se ampliam e a FEIRATUR ${ }^{12}$ se destaca como um espaço de negócios e debates sobre o segmento, em especial quanto no âmbito das temáticas relacionadas às inquietações dos empreendedores, como o financiamento e a necessidade de se consolidarem estratégias de colaboração. Em 2005, é realizada uma oficina no SENAC - Serviço Nacional de Aprendizagem Comercial (São Paulo) - para discutir o Turismo Rural Paulista, cujo principal objetivo é reunir representantes do poder público de diversos municípios, de organizações de turismo rural e de empreendedores para se conhecerem e fortalecerem suas ações conjuntas.

Andréia Roque ${ }^{13}$, que assume na época a presidência da ABRATURR - Associação Brasileira de Turismo Rural, em São Paulo, ressalta a importância deste encontro refletida na elaboração das "Diretrizes do Turismo Rural Paulista". Assim, em 2008, ocorre em Atibaia, o $1^{\circ}$ Encontro do Turismo Rural Paulista, que tem como proposta principal oferecer

\footnotetext{
${ }^{12}$ Feira de Turismo Rural evento de cunho técnico comercial também se constituiu um espaço importante de aproximação entre os profissionais, pesquisadores e empreendedores de turismo rural.

13 Andréia Roque, ex-presidente da ABRATURR e atual diretora do IDESTUR - Instituto de Desenvolvimento do Turismo Rural, consultora e empresária do segmento de turismo rural.
} 
visibilidade aos empreendimentos e organizações do segmento, no denominado "Vitrine do Turismo Rural Paulista”, realizado desde então sob a coordenação da ABRATURR. (Roque, 2016)

Esta maior visibilidade que o turismo paulista alcança também é consequência de um esforço para mapear os empreendimentos e caracterizá-los, concretizado na publicação dos resultados de um amplo levantamento intitulado "Guia Turismo de Campo: Turismo Rural no Estado de São Paulo" (Roque, 2006), amplamente utilizado pelos investigadores por disponibilizar informações sobre mais de 800 empreendimentos de turismo rural no Estado. A necessidade de mobilização e articulação do segmento estimula e promove a sua inserção nas discussões sobre o desenvolvimento do turismo no estado, com a criação da Câmara Setorial de Turismo Rural, no Conselho Estadual de Turismo, em 2010.

Neste período organizações como o Serviço Nacional de Apoio ao Pequeno Empreendedor (SEBRAE) e o Instituto Interamericano de Cooperación para la Agricultura (IICA), realizam alguns estudos sobre o turismo rural no país, encontrando grande dificuldade para dimensionar e caracterizar os empreendimentos. Entre os resultados obtidos, destacam-se a necessidade premente de profissionalização do segmento, uma maior e mais eficiente articulação entre as entidades e organizações que atuam com turismo rural, a adequação da legislação às especificidades do segmento, e a imprescindível definição "dos critérios, parâmetros e conceitos" sobre turismo rural para a efetividade de ações e intervenções (IICA, 2009, p. 44); questões também verificadas por Santos (2008, p.111), que salienta a ausência de estudos sobre a demanda de turismo rural.

É nesse cenário desafiador e complexo que emergem uma série de investigações sobre o tema no país, chegando a 72 dissertações e 18 teses, refletindo um incremento na quantidade de doutorados em relação ao período anterior, que também é um indicativo de estudos de maior envergadura e profundidade. Contudo, a realidade do Estado de São Paulo foi tratada 
em apenas 6 (seis) estudos abordando diferentes aspectos, sendo que dois deles têm as fazendas históricas como local de estudo.

O primeiro trabalho de Faustino (2006) analisa as interfaces entre o patrimônio e turismo rural a partir da experiência das fazendas Ibicaba, em Cordeirópolis, e Capoava, em Itu. O segundo de Morais (2010), na Fazenda Santo Antonio do Pinhal, em São Carlos, analisa a oferta de atividades de lazer para idosos, a partir de uma perspectiva de educação patrimonial. Esta dissertação é um dos produtos de amplo projeto de pesquisa intitulado "Patrimônio Rural Paulista: Espaço privilegiado para Pesquisa, Educação e Turismo”, [MR21] coordenado pelo Prof. Dr. Marcos Tognon, da UNICAMP - Universidade de Campinas, no período de 2008 a 2012.

Esse projeto teve o intuito de "reconhecer a especificidade de todos os bens materiais e imateriais das fazendas, valores consagrados pelas práticas, acervos, técnicas e tecnologias, estruturas edificadas e paisagem cultivada ou natural que caracterizam, de forma independente, cada um dos territórios rurais" (Costa et al., 2013, p. 123). Com o apoio da FAPESP - Fundação de Apoio à Pesquisa no Estado de São Paulo, foi realizado em parceria com Associação das Fazendas Históricas Paulistas, e teve adesão de 16 fazendas dos Núcleos Itu, Mococa, Campinas, Limeira, São Carlos e Vale do Paraíba (Costa et al., 2013, p. 122). A questão do turismo que permeou as discussões, trazia uma proposta de atividades e roteiros apoiados nos princípios da educação patrimonial, que resultou num amplo levantamento do patrimônio e em recomendações para aprimorar a atuação como atividade turística.

As fazendas históricas paulistas têm uma demanda de visitação pequena, mas constante, como observado nos relatórios da pesquisa, o que levou à criação de algumas organizações, como a Associação das Fazendas Históricas Paulistas, em 2004, com " duas diretrizes que são comuns: as Fazendas Históricas enquanto locais privilegiados para visitação, almoços, passeios ecológicos, reuniões de negócios ou comemorativas, casamentos, batizados, 
hospedagem, pesquisa e ensino, e também a ostensiva luta para preservação de nosso Patrimônio Histórico Natural e Construído” (Associação das Fazendas Históricas Paulistas, 2016); e mais recentemente, em 2009, a $\mathrm{ARCCO}^{14}$ - Associação Roteiros Caminhos da Corte, na região do Vale Histórico do Estado de São Paulo.

Dos 23 estudos sobre o turismo rural em São Paulo neste período, 5 têm as fazendas históricas como seu objeto de estudo, dentre as quais se destaca a Fazenda Capoava ${ }^{15}$, em Itu, e depois a Fazenda Águas Claras, em Itapira, a Fazenda Ibicaba, em Limeira, a Fazenda Nova, em Mococa e as Fazendas Históricas de Ribeirão Preto. (Carvalho, 2012; Cunha, 2004; Dias, 1996; Faustino, 2006; Morais, 2010).

Além da importância na história de São Paulo, muitos pesquisadores motivados pela preocupação em preservar este patrimônio e observando o potencial turístico que apresentam, têm se dedicado a entender este universo e refletir como o turismo poderia contribuir para sua valorização e principalmente gerar recursos para sua preservação. Neste sentido Pires (2001a, 2001b) já provocava questionamentos sobre a temática do turismo cultural apoiado neste patrimônio no Vale Histórico.

Mas parece que pouco se conseguiu avançar nesta direção, apesar dos esforços dos proprietários das fazendas e dos pesquisadores. No início da década de 2010, Queiroz (2012) elaborou um estudo comparativo das Fazendas Históricas Paulistas com os Solares Portugueses, detectando que as dificuldades podem estar associadas a questões culturais mais complexas. Certamente é um tema desafiador, que, entretanto, não está no escopo deste estudo.

\footnotetext{
${ }^{14}$ ARCCO - Associação Roteiros Caminhos da Corte. Recuperado em 10 de julho de 2016, de: http://www.caminhosdacorte.com.br/portal/a-associacao/.

${ }_{15}$ A Fazenda Capoava tem uma proposta de negócio turismo rural apoiada no ambiente rural e na sofisticação dos serviços oferecidos, com uma atuação bastante profissional neste mercado. Assim como a Fazenda Águas Claras, sendo que as duas fazem parte do Roteiros de Charme marca que congrega produtos de luxo, hotéis temáticos, hotéis boutique.
} 
A região do Vale Histórico também foi objeto de estudo de Blos (2007) que buscou compreender como a experiência turística em espaços rurais se manifesta na vida dos paulistanos que visitaram a região.

Os desafios de construir ações colaborativas no turismo rural paulista, tem estado presente em vários estudos, e acabam retornando em diferentes momentos, como é o caso da investigação de Bernardi (2009) que se dedicou a compreender a dinâmica da Associação do Circuito das Frutas ${ }^{16}$, que congrega os empreendimentos de turismo rural daquela região, identificando alguns dos obstáculos que interferem na construção e na operação do Circuito, o que complementa as discussões propostas por Gonçalves (2004).

A valorização do turismo rural por seus efeitos positivos ainda estimula os pesquisadores, como o trabalho de Severino (2006) que tratou de identificar o potencial de desenvolvimento do turismo rural no entorno de uma área de preservação ambiental, o Parque Estadual de Jataí, como estratégia para minimizar os impactos a esta unidade de conservação. Com a mesma perspectiva de vetor de desenvolvimento, Soares (2007) analisa as contribuições que o turismo pode trazer para os municípios de Cunha, Santo Antonio do Pinhal e Louveira.

Verifica-se que enquanto questões de ordenamento e competitividade estavam na pauta das discussões nacionais, os estudos paulistas se empenham em descortinar as relações entre patrimônio e turismo rural sob a perspectiva de preservação e, portanto distante das demandas de informação indicadas por aqueles envolvidos no cotidiano do turismo rural.

\footnotetext{
16 Existe uma diferença entre a Associação do Circuito das Frutas que congrega os empresários e o Circuito das Frutas, que é um consórcio intermunicipal que congrega representantes das prefeituras das cidades.
} 


\subsubsection{A caminho da segunda geração do turismo rural (2011 a 2015)}

Como resultado das investigações sobre a produção científica sobre turismo rural no país até o início da década de 2010, Solha (2012) verifica que de modo geral as temáticas e os objetivos estavam em consonância com as demandas de conhecimento e informação que emergiam nos congressos científicos, e nos encontros da iniciativa privada e do poder púbico. Tal situação permanece, mesmo que vários dos temas que ainda continuam na pauta dos empreendedores de turismo rural não tenham se tornado objeto de estudo das investigações, como as questões relacionadas a legislação e financiamento do segmento (Solha, 2013).

Neste sentido Lane (2014) traz uma avaliação bastante crítica acerca da produção científica sobre o assunto, ao dizer que:

- tendiam a ser descritivas, usando com frequência o método de estudos de casos.

- tendiam a ser executadas para propósitos acadêmicos - provocando desenvolvimento e reações, ao invés de procurar respostas administrativas para questões emergentes.

- tendiam a elogiar ou condenar rapidamente. As avaliações equilibradas eram raras, pois era muito difícil executar estudos holísticos profundos, em longo prazo, dentro dos parâmetros financeiros da época.

- os acadêmicos do turismo e sociólogos rurais eram ativos na área de turismo rural.

- os pesquisadores viam o turismo rural como sendo possível de seguir os princípios do ciclo de vida de destinos turísticos, sem pensar sobre o que aconteceria depois [...]

- evitavam questões de normatização e administrativas em níveis internacionais, nacionais, locais e regionais.

- poucos trabalhos foram realizados a fim de explorar os requisitos de mercado do turismo rural em suas várias formas. 
Esta situação também foi verificada nos estudos de Solha e Rejowski (2013) sobre a as pesquisas brasileiras, que ressaltam haver "pouco avanço no que se refere aos estudos de demanda e nas relações com o consumidor de turismo e menos ainda com a aplicação das tecnologias da informação" (p. 119).

Desde de 2012, pode-se observar que os investigadores de turismo rural estão num processo de ponderação que tem se aprofundado, questionando inclusive as suas próprias escolhas e abordagens temáticas e metodológicas. Tais preocupações aparecem oficialmente na temática da $10^{a}$ edição do CITURDES, 2016, intitulada Turismo en espacio rural: balance critico.

Enquanto isso, no âmbito nacional o segmento de turismo rural conquista alguns reconhecimentos, como por exemplo a recente aprovação no Senado Federal do Projeto de "Lei 5077/2009”, que promove o enquadramento legal para o turismo rural, incluindo-o no rol de atividades turísticas (Roque, 2014). Por outro lado, perde espaço nas políticas públicas federais, com a reorganização dos ministérios e a ausência de perspectivas claras para os próximos anos.

Todavia, percebe-se uma, ainda que tênue, mudança de atitude dos gestores municipais e estaduais em relação ao turismo rural, que segundo Roque (2016) se deve principalmente ao posicionamento mais incisivo e profissional dos empreendedores de Turismo Rural no Estado de São Paulo. O segmento já provou ao longo de sua trajetória, quase 30 anos desde os seus primeiros empreendimentos, que é capaz de gerar fluxos de visitantes de modo sistemático. Roque (2016) destaca o papel fundamental da APRECESP - Associação das Prefeituras Estâncias do Estado de São Paulo - que no início apoiava a promoção do segmento, mas atualmente tem compreensão sobre sua capacidade de gerar negócios para os municípios associados.

Neste ínterim, o Encontro do Turismo Rural Paulista, organizado pela ABRATURR, tem se consolidado e se tornado um espaço importante para garantir visibilidade aos 
empreendimentos e compartilhar experiências entre os diversos setores que atuam no segmento.

Ao longo dos últimos dez anos desta década, pode-se observar o surgimento de novos núcleos de turismo rural e a consolidação de outros. Ao avaliar as fragilidades e a potencialidades do turismo rural paulista neste momento, Roque (2016) aponta para a ausência de novas liderança com pensamento estratégico, que considera essencial para lidar com as demandas emergentes e as profundas transformações que vem ocorrendo no mundo rural. Por outro lado, destaca que no Estado de São Paulo existe turismo rural de fato, distribuído por todo o território, em função da existência de demanda turística nos grandes centros urbanos como Campinas, Ribeirão Preto e São José dos Campos, além da capital do Estado. A permanente mobilização dos empreendedores de turismo rural no estado permite que o turismo rural paulista seja reconhecido com núcleos associativos locais e estadual com forte representatividade. (Roque, 2016)

Nos últimos anos tem-se discutido em todos os âmbitos as profundas transformações sociais, econômicas e ambientais, que colocam em dúvida, valores, crenças e comportamentos. De certa forma os estudos sobre turismo rural em São Paulo nestes últimos anos parecem refletir isso, em função do aprofundamento e dos recortes das discussões propostas. Embora com uma produção pequena em quantidade, revela um amadurecimento no entendimento e nas definições de prioridades de temáticas.

Assim, com um minucioso estudo sobre as propriedades e os bairros rurais, na região de Piedade e Pilar do Sul, Moreira (2012) apresenta elementos que permitem compreender a complexidade das relações do turismo rural num espaço rural. Revela a valorização das diferentes imigrações de portugueses, japoneses e italianos com seus saberes-fazeres rurais na configuração desta região do cinturão-verde de São Paulo, também como área de lazer e turismo para a população paulistana. 
Geraldo (2012) procura caracterizar e descrever a experiência dos empreendimentos de turismo rural localizados em alguns municípios da região da Cuesta Paulista ${ }^{17}$, ressaltando também a forte relação entre os produtos e serviços ofertados com as características da exploração rural da região.

Carvalho (2012) permeia a discussão a partir da perspectiva da hospitalidade em fazendas históricas paulistas, escapando da tradicional leitura da questão do patrimônio edificado ao contextualizar o uso do patrimônio material também a partir do patrimônio imaterial. Desenvolve uma reflexão instigante sobre estas relações e aquilo que o turista busca ao visitar o empreendimento rural, concluindo que

[...] em se tratando das fazendas históricas enquanto equipamentos a serem considerados na atividade turística, destaca-se a importância da noção simbólica da hospitalidade, suas trocas sociais, o equilíbrio entre o paradoxo do doméstico versus o comercial, da interpretação de valores se apropriações que ressignificam a dinâmica operacional das históricas paulistas e o turismo enquanto veículo que proporciona essas vivências culturais de solidariedade e de afetividade como variáveis de construção dessa nova hospitalidade rural, ou seja, a operacionalização das práticas sociais e a sua transformação, de forma natural, em argumento de atração. (Carvalho, 2012, p. 126)

Assim, enquanto Carvalho (2012) propõe uma abordagem inovadora para uma antiga questão, Pinho (2014) apresenta uma nova temática, ao explorar a percepção dos extensionistas da CATI $^{18}$ - Coordenadoria de Assistência Técnica Integral, sobre sua atuação no segmento de turismo rural. Isto se dá em função de sua atuação profissional e da avaliação

\footnotetext{
${ }^{17}$ Cuesta é uma forma de relevo em que colinas e montes têm um declive não simétrico, ou seja, suave de um lado e íngreme do outro. Em São Paulo é conhecida como Cuesta Paulista, abrange a região de Botucatu, sendo predominante também nos municípios de Águas de São Pedro, Itirapina, Analândia, Torrinha, Brotas, São Carlos, Santa Rita do Passa Quatro e Altinópolis, dentre outros.

${ }^{18}$ A Coordenadoria de Assistência Técnica Integral (CATI) constitui o órgão oficial, sob administração direta da Secretaria Estadual de Agricultura e Abastecimento, responsável por ações de extensão rural pública junto aos produtores rurais no Estado de São Paulo.
} 
de que "a inexistência de um projeto institucional voltado ao turismo rural dificulta caracterizar o atendimento dos extensionistas da CATI à demanda dos produtores nesta área, bem como perceber se existe ainda a preocupação com um turismo que seja desenvolvido de maneira mais sustentável" (Pinho, 2014, p. 16). Como resultado salienta que seria fundamental

[...] a presença do extensionista em seu papel de mediador entre o produtor rural e os demais agentes externos portadores do discurso do turismo como indutor de desenvolvimento. Caberia a ele a missão de compreender os diversos aspectos relativos às novas ruralidades resultantes das transformações ocorridas no meio rural, e a partir daí, conforme afirmam Deponti e Almeida (2008), realizar uma mediação de maneira a mais neutra possível [...]. (Pinho, 2014, p. 62).

Ainda que timidamente, os estudos deste período começam a refletir as transformações que estão em curso, algumas delas foram identificadas por Lane (2014) e parecem conformar um novo momento do turismo rural, o qual ele denominou como Turismo Rural de Segunda Geração, e que traz deverá estimular os pesquisadores a explorarem novas temáticas e abordagens. E nesse sentido sugere algumas questões que poderiam examinadas, como por exemplo

- a validade dos conceitos e atributos de turismo rural no panorama atual e para novas estratégias de desenvolvimento, como os destinos rurais;

- a incorporação do uso de dados sobre comportamento de visitantes nas estratégias de planejamento de produtos e serviços;

- o uso da tecnologia da informação na oferta de informação de qualidade para os visitantes e na formatação de produtos e serviços;

- o uso efetivo do marketing para ganhar competitividade e valorizar o diferencial do segmento; 
- o papel das redes e das parcerias no sucesso das diferentes iniciativas no âmbito do turismo rural; entre outros.

Além de considerar as temáticas que se relacionam à realidade europeia, os estudos sobre o estado de São Paulo em particular, poderiam contribuir para descortinar a experiência paulista no turismo rural, diante algumas mudanças que já vem sendo percebidas por aqueles que atuam no segmento, como por exemplo a presença cada mais relevante dos jovens empreendedores e a influência dos empresários neorurais, com formação em diferentes áreas do conhecimento, na gestão de empreendimentos rurais. (Roque, 2016)

Mazuel (2000) ao tratar da relação entre o patrimônio cultural e o turismo rural na França, destaca a necessidade de

[...] atentar para as leis da oferta e da demanda, elementos que o turismo rural francês ignorou durante muito tempo, igualmente como em qualquer atividade mercantil, mesmo se esta é muito específica, pois não se pode vender seu passado e sua cultura com se esse fosse uma caixa de sabão em pó. Há quem o faça assim na América do Norte e na Europa, perdendo aquilo que lhe é essencial: a memória para melhor preparar o futuro. (2000, p.113)

Observa-se que esta é uma questão latente nas discussões contemporâneas do turismo rural e que deve ser considerada seriamente nos estudos da área, que poderiam priorizar abordagens de marketing, de comunicação e de tecnologia da informação. E desta forma se aproximar das demandas de informação e conhecimentos daqueles que atuam no segmento.

Afinal, se um dos desafios contemporâneos do turismo rural é ter claramente definida a experiência memorável que se quer ofertar para o turista, há que se dedicar esforços na geração de subsídios para que gestores públicos, profissionais e empreendedores do turismo 
rural possam elaborar e ofertar produtos e serviços que revelem e valorizem a cultura rural paulista. 
3 Turismo Rural como Negócio:

Empreendimentos em São Paulo 


\title{
3.1 Delineando o cenário
}

Os empreendimentos de turismo rural ao mesmo tempo que podem revelar e valorizar a cultura rural de uma região, também resultam das transformações que ocorrem nestes territórios, como atentam Roscoche e Carvalho (2006) ao discutir as implicações das diferenças regionais na configuração do turismo rural nas diferentes regiões brasileiras, destacando que

\begin{abstract}
As diferentes características de colonização, por exemplo, são responsáveis pelas atuais configurações culturais e socioeconômicas, que estão diretamente ligadas ao modo de lidar com a terra e a independência econômica de seus proprietários. No Nordeste, região caracterizada pelo patriarcalismo e pela monocultura, as propriedades rurais que cultivavam a cana-de-açúcar perderam a importância econômica e tiveram que buscar novas oportunidades para aproveitar os equipamentos ociosos. Já no Paraná, a cultura imigrante [que incentivava as pequenas propriedades autossuficientes] permite que grande parte dos agricultores e pecuaristas possam se dedicar ao turismo, nem necessariamente abandonar as atividades tradicionais. (p. 278)
\end{abstract}

Isto certamente reflete-se nas características dos produtos e serviços de turismo rural que venham a ser ofertados, mas devem ser consideradas juntamente com outros elementos que, articulados ou não, propiciam condições para que este rural não seja apenas um recurso, mas se conforme como um segmento turístico. Entre eles destacam-se as organizações e entidades que atuam na facilitação e no apoio à implementação e operação dos empreendimentos de turismo rural.

Verifica-se que o poder público na esfera federal teve relevante papel nas discussões e nos avanços que foram implementados na promoção do turismo rural no país, desde meados de 1990. Contudo essa mesma intensidade de atuação não se verificou no âmbito do poder público no Estado de São Paulo, exceto pela criação da Câmara Setorial de Lazer e Turismo no Meio Rural, em 1998, vinculada à Secretaria da Agricultura. Segundo Roque (2016), sua atuação é referência nacional, na medida que foi pioneira na articulação das discussões entre 
o rural e o turismo. E em 2010, cria-se Câmara Setorial de Turismo Rural, no Conselho Estadual de Turismo.

Apesar de ter um espaço formal de debates dentro da Secretaria da Agricultura, os empreendedores de turismo rural contam com uma atuação bastante incipiente da CATI, responsável pela atividade de extensão no turismo rural. Pinho (2014) salienta a ausência de um projeto institucional voltado ao turismo rural, apontando a existência de ações pontuais como a realização em 2005 de um Seminário Estadual de Turismo e Artesanato Rural na Agricultura Familiar, e a criação em 2010 de uma Comissão Técnica específica para assuntos relativos ao turismo rural.

Ressalta que em função da ampla capilaridade que tem no Estado, com a presença das Casas de Agricultura e o corpo técnico de extensionistas que atuam com grande proximidade aos produtores rurais, poderia exercer um importante papel de mediador entre o produtor rural e os demais atores sociais envolvidos no segmento do turismo rural (Pinho, 2014). A presença pífia do poder público estadual e municipal na articulação, debate e orientação do desenvolvimento do segmento de turismo rural, ao longo de todo o período analisado, gera uma lacuna que é ocupada por algumas entidades do Sistema $\mathrm{S}^{19}$.

No Estado de São Paulo destaca-se a atuação do SEBRAE-SP desde 1995, quando implementou o programa "Volta ao Campo", oferecendo palestras de sensibilização e assistência técnica para os pequenos produtores rurais do interior do estado. Esteves (2001) revela ainda que este esforço atingiu mais de 1000 produtores rurais em 1996, com a posterior realização de diagnósticos de viabilidade e desenvolvimento de projetos específicos para 15

\footnotetext{
19 Termo que define o conjunto de organizações das entidades corporativas voltadas para o treinamento profissional, assistência social, consultoria, pesquisa e assistência técnica, que além de terem seu nome iniciado com a letra S, têm raízes comuns e características organizacionais similares. Fazem parte do sistema S: Serviço Nacional de Aprendizagem Industrial (Senai); Serviço Social do Comércio (Sesc); Serviço Social da Indústria (Sesi); e Serviço Nacional de Aprendizagem do Comércio (Senac). Existem ainda os seguintes: Serviço Nacional de Aprendizagem Rural (Senar); Serviço Nacional de Aprendizagem do Cooperativismo (Sescoop); e Serviço Social de Transporte (Sest). Recuperado em 10 de agosto de 2016, em: http://www12.senado.leg.br/noticias/glossario-legislativo/sistema-s.
} 
propriedades. O segmento do turismo rural esteve presente também no âmbito de inúmeros projetos de desenvolvimento turístico elaborados e implementados pela entidade, que restringiu suas iniciativas nesta área nos últimos anos, em decorrência de alteração de suas estratégias de ação.

O SENAR - Serviço Nacional de Aprendizagem Rural - em parceria com a FAESP — Federação da Agricultura e Pecuária do Estado de São Paulo, tem presença marcante no cenário do turismo rural paulista desde 2004, quando propôs o Programa de Turismo Rural, que tinha como objetivo ampliar o olhar sobre a propriedade rural, fornecendo ferramentas para identificar e implantar negócios de turismo, de acordo com os recursos encontrados no meio, aliados às habilidades e vocações do produtor rural e sua família. Desde então, tem mantido uma atuação permanente, principalmente na oferta de treinamentos, inclusive com novas abordagens como: monitoria na propriedade de turismo rural, promoção e comercialização de turismo rural, turismo pedagógico no meio rural. (FAESP \& SENAR, 2010, 2011).

As duas entidades SEBRAE/SP e SENAR, além de promover a capacitação técnica dos empreendedores de turismo rural, têm grande envolvimento nos debates do segmento apoiando e participando de vários eventos técnicos, científicos e comerciais no Estado.

Em 2002, registra-se uma única iniciativa do SESCOOP/SP ${ }^{20}$ - Serviço Nacional de Aprendizagem do Cooperativismo, junto a 41 propriedades do Circuito das Frutas, numa ação intitulada "Programa de turismo rural cooperativo", que tinha por objetivo possibilitar uma renda alternativa ao produtor, além de estimular o associativismo e o cooperativismo.

De modo geral, observa-se a tendência dos empreendedores de turismo rural paulistas em organizarem-se em associações. Esta característica permitiu a Bovo (2004) analisar o turismo

\footnotetext{
${ }^{20}$ SESCOOP/SP apresenta turismo rural cooperativo na Agrotec Fruticultura. Recuperado em 10 de janeiro
} de 2016, de: http://www.ocb.org.br/site/agencia_noticias/noticias_detalhes.asp?CodNoticia=4423. 
rural no Estado a partir da perspectiva de um conjunto de associações: Associação de Turismo Rural de Ribeirão Preto e Região (ATURP), Associação de Turismo Rural do Circuito das Frutas (ATRCF), Associação do Turismo Rural do Médio Tietê (ASTUR), Associação Brasileira de Turismo Rural (ABTR), Associação Natureza Café com Leite (ANCL), sendo que as de caráter regional tem forte atuação até os dias atuais. Entretanto, com caráter de representação estadual tem-se a ABRATURR/SP - Associação Brasileira de Turismo Rural, que representa o segmento em todos os espaços de discussão no estado, participando e realizando eventos e acompanhando e dando visibilidade para as demandas dos seus associados.

A viabilização de uma parceria entre a Secretaria de Turismo de São Paulo, ABRATURR/SP e a Editora Turismo de Campo, em 2006, resultou no primeiro Guia de Turismo Rural do Estado de São Paulo. O documento tem sido amplamente utilizado pelos profissionais, empreendedores e pesquisadores como referência para localizar 844 empreendimentos de turismo rural, além de contemplar diversas modalidades de negócios de turismo rural em todo o território paulista. (Roque, 2006).

Além de disponibilizar informações sobre os serviços oferecidos, essa publicação apresenta uma breve análise do conjunto de empreendimentos de turismo rural identificados a partir um extenso levantamento de material promocional de empreendedores, material promocional de prefeituras, dados da Secretaria de Turismo, dos circuitos turísticos e das associações, complementado por um questionário respondido pelos proprietários destes estabelecimentos. A sistematização desses dados gerou o documento intitulado Indicadores do Turismo Rural Paulista, disponibilizado como parte do Guia, com informações resumidas sobre as modalidades de turismo rural, a distribuição dos empreendimentos no território e o perfil do público. Infelizmente, apesar da proposta de continuidade, foi a única iniciativa que trouxe dados mais detalhados sobre o segmento de turismo rural no Estado de São Paulo, e 
que ainda é uma referência para subsidiar as ações de gestores públicos, profissionais e pesquisadores da área.

Em 2008, a Secretaria da Agricultura e Abastecimento realizou o mais recente Levantamento Censitário de Unidades de Produção Agropecuárias (Projeto LUPA), no qual pode identificar, entre outras questões, oito categorias de atividades econômicas não agropecuárias:

- Esporte e lazer - existência de alguma atividade econômica ligada à prática de esportes e/ou lazer (desde que a UPA ${ }^{21}$ não se constitua num Hotel Fazenda ou Pousada), por exemplo, aluguel de embarcações para passeio, de quadras ou campos para a prática de esportes, de animais para passeio, de equipamentos para a prática de esportes, de estrutura para a prática de arborismo etc.;

- Hotel Fazenda / Pousada / Spa - exploração parcial ou integral, como um Hotel Fazenda, Pousada ou Spa, possuindo para tanto, instalações e acomodações específicas;

- Pesque-pague - existência de alguma atividade econômica do tipo pesque-pague, ou similar, como "pague e pesque". Este item não deve ser confundido com as atividades econômicas de piscicultura, como criação de alevinos, recria, engorda entre outros;

- Restaurante / Lanchonete - existência de alguma atividade econômica ligada ao comércio de alimentos e/ou bebidas, tais como restaurante, lanchonete, bar e similares;

- Turismo rural/ecoturismo - existência de alguma atividade econômica ligada ao turismo rural ou ao ecoturismo, isto é, a realização de atividades grupais ou excursões por roteiros previamente definidos, como as trilhas ecológicas, através de caminhada ou com o uso de animais, com fins de contemplação da flora, da fauna e das belezas naturais. Difere-se de Hotel Fazenda por não possuir acomodações para hospedagem, e em relação

\footnotetext{
21 Termo utilizado para definir Unidade de Produção Agropecuária.
} 
ao aluguel de animais do item Esporte e Lazer, difere-se por possuir atividades previamente programadas;

- Extração mineral - existência de alguma atividade econômica ligada à extração de produtos minerais na UPA, por exemplo, brita (pedreira), areia para construção, argila para cerâmica ou artesanato, turfa, terra vegetal, água mineral, minérios etc.;

- Agroindústria - existência de algum tipo de agroindústria (registrada e com marca própria, o que a distingue da produção artesanal), com a transformação em produtos mais elaborados, para comercialização;

- Transformação artesanal - existência de alguma atividade ligada à comercialização informal de produtos que passaram por qualquer processamento artesanal, por exemplo, doces, queijos, manteiga, sucos naturais, embutidos de carne e derivados, aguardente, farinha de mandioca, pamonha, vassoura, artesanatos em couro ou madeira, composto orgânico, húmus etc. (São Paulo, 2008)

O levantamento identificou 324.601 unidades produtivas rurais (UPA) no Estado, embora a quantidade de propriedades com atividades não-agrícolas seja pouco expressiva em relação ao total $(1,66 \%)$, como apresentado na Tabela 4. O registro da sua existência é um indicador importante de que o rural paulista está sujeito s mesmas transformações observadas em outras regiões do país. 


\section{Tabela 4 - Atividades Econômicas Rurais não Agropecuárias, Estado de São Paulo - $2007 / 2008$}

\begin{tabular}{|l|c|c|}
\multicolumn{1}{|c|}{ ITEM } & $\begin{array}{c}\text { Número de } \\
\text { UPAs }\end{array}$ & Percentual \\
\hline Agroindústria & 425 & 0,13 \\
Esporte e Lazer & 1999 & 0,62 \\
Extração Mineral & 409 & 0,13 \\
Hotel Fazenda / Pousada / Spa & 460 & 0,14 \\
Pesque-Pague & 627 & 0,19 \\
Restaurante / Lanchonete & 694 & 0,21 \\
Transformação Artesanal & 425 & 0,13 \\
Turismo Rural / Ecoturismo & 370 & 0,11 \\
\hline
\end{tabular}

Nota. Fonte: São Paulo (2008).

Observa-se que neste conjunto de atividades não-agrícolas se sobressaem aquelas relacionadas às atividades de lazer ou de turismo, que podem estar ocorrendo de forma concomitante na mesma propriedade rural. Dentre elas destaca-se a categoria Esporte e Lazer $(0,62 \%)$, provavelmente em função da amplitude conceitual considerada, seguida pelos Restaurantes/Lanchonete (0,21\%), Pesque-pague (0,19\%), Hotéis-Fazenda/Pousada/Spa $(0,14 \%)$ e Turismo Rural/Ecoturismo (0,11\%). (Tabela 4)

Os indícios desta presença emergem em diferentes documentos como no Censo Agropecuário, realizado pelo IBGE (2011, 2015), e nos artigos de Silva (1996, 2000) que detecta também a expansão dos pesque-pague, mas não compreende se este um fenômeno mais amplo e diverso. As chácaras de recreio, tema discutido profundamente por Tulik (2001), é apenas umas das facetas deste movimento de uso do espaço rural para atividades de lazer e turismo, como pode ser observado nos dados da Tabela 4.

Entretanto uma análise mais acurada do significado destes dados não é possível, pois as categorias de análise que foram utilizadas são muitos amplas e não correspondem aos conceitos e atributos discutidos acerca do que pode ser considerado turismo rural. Neste sentido vale ressaltar que os dois levantamentos apresentados revelam deficiências semelhantes, ocasionadas pelo uso de conceitos diferentes e muito amplos. Além disso, os dados têm quase uma década e provavelmente o panorama atual já está muito diferente. 
Então qual é mesmo a realidade do turismo rural paulista? São os mais de 800 empreendimentos indicados pelo Guia de Turismo Rural? São as 1.999 UPAS com atividades de esporte e lazer? Ou são aquelas com Turismo Rural/Ecoturismo? Como pensar em políticas públicas, planejamento, financiamento, capacitação para um conjunto de empreendimentos no Estado com tão pouca informação atualizada disponível?

\subsection{Percurso metodológico}

Diante de um cenário complexo e complicado, a ABRATURR, em 2014, resolve reeditar o levantamento da Turismo de Campo, e retoma os formulários (Anexo A) com algumas adequações, disponibilizado-o on line. Convida por email os empreendedores de turismo rural cadastrados na associação, inclusive aqueles que participaram das diferentes edições do Encontro Paulista de Turismo Rural, e também contata empreendedores que estão nos bancos de dados da APRECESP e dos Roteiros e Circuitos de Turismo de São Paulo. Ao final tem uma lista com 350 emails de empreendedores e empreendimentos de turismo rural. Este levantamento realizado entre junho e setembro 2014 conseguiu um retorno de 229 questionários preenchidos, ou seja, $65,42 \%$ de questionários respondidos on-line. Esse é um excelente resultado, considerando que é um público naturalmente distante do uso da tecnologia, seja por estilo de vida, seja pelo acesso por vezes deficiente aos recursos tecnológicos. Portanto, este volume de respostas é um contundente indicador do interesse dos empreendedores e também um reconhecimento da associação.

Mas logo se depara com um problema, como tratar e analisar os dados levantados? Com o intuito de solucionar esta questão firmou-se uma parceria entre a ABRATURR e esta pesquisadora, em função de interesses comuns. Deu-se início então a este estudo 
caracterizado como levantamento ou survey (Ferri, 2011) sobre o negócio do turismo rural no estado de São Paulo na visão dos seus empreendedores, com base nos dados levantados na pesquisa da ABRATURR, ou seja, em dados secundários.

Como não havia um projeto de pesquisa com preocupações metodológicas, seja na elaboração do questionário ou mesmo na coleta de dados, o processo exigiu um grande esforço na tarefa de tratamento e sistematização dos dados, que demandou um tempo maior do que esperado para enfim disponibilizar-se de informação de maior qualidade.

Desta forma, foram excluídas 27 respostas repetidas, 2 referentes a eventos e 2 com falta da cidade de localização do empreendimento, com o que se chegou a uma amostra de 198 empreendimentos.

Em seguida foram selecionadas as principais questões pertinentes aos estudos e excluídas as questões referentes a dados institucionais dos empreendimentos ${ }^{22}$; e as respostas em branco e as inconsistentes, as quais foram tradas como Não Informado nas tabelas e gráficos analisados. Por fim, as respostas que não puderam ser classificadas em categorias apropriadas foram classificadas em Outros.

Após estes ajustes, as respostas foram sistematizadas, as variáveis simples foram ajustadas em categorias reduzidas, e as variáveis múltiplas foram separadas em outras colunas. Realizados todos os ajustes no arquivo em EXCEL, foram gerados os dados e tabelas pelo SPSS $22.0^{23}$.

Compreende-se que o resultado obtido neste levantamento tem algumas limitações metodológicas, mas ao mesmo tempo salienta-se que não seria possível obter novamente a atenção e a disponibilidade destes empreendedores em um novo estudo, sem apresentar os resultados da consulta anterior. A análise dos dados está disposta em quatro categorias

\footnotetext{
22 Questões do questionário desconsideradas para análise: 4; 14; 17 a 21; 23 a 28; 34; 37 e 38.

23 SPSS, originalmente significada Statistical Package for the Social Sciences, é um software da IBM para pesquisas quantitativas.
} 
elaboradas para responder algumas questões chave: Quem é o empreendedor de turismo rural? Como é a atividade de turismo rural nos empreendimentos? Como está estruturado o negócio? Quem são os visitantes?

No empreendedor, caracteriza-se o respondente do questionário identificando a sua ocupação. $\mathrm{Na}$ atividade, tem-se a distribuição espacial e os atrativos e diferenciais dos empreendimentos. Na estrutura do negócio, aborda-se o tempo de atuação, os trabalhadores e as práticas agrícolas. E por fim, no perfil da demanda trata-se do local de origem e as estratégias comerciais e de divulgação. Esse é o conjunto de variáveis consideradas, conforme os dados disponibilizados, cujo tratamento e análise apresenta-se a seguir.

\subsection{Empreendedores}

$\mathrm{Na}$ pesquisa, a maioria dos respondentes pelos estabelecimentos (49\%) foram os próprios proprietários, seguido pelos sócios proprietários (16,2\%), funcionários responsáveis pela gerência/coordenação e diretoria $(16,6 \%)$ e analista/consultor $(8,6 \%)$, além de outros $(3,5 \%)$; uma minoria não informou a ocupação (Figura 12). Este interesse direto dos proprietários e sócios proprietários $(65,2 \%)$ é um indicador positivo do interesse em participar efetivamente de ações que permitam gerar informações de qualidade sobre o segmento. Também significa que precisa haver um compromisso com o retorno e a discussão dos resultados com aqueles que responderam prontamente à solicitação, mas também promover uma ampla difusão para aqueles que atuam direta ou indiretamente no segmento. 


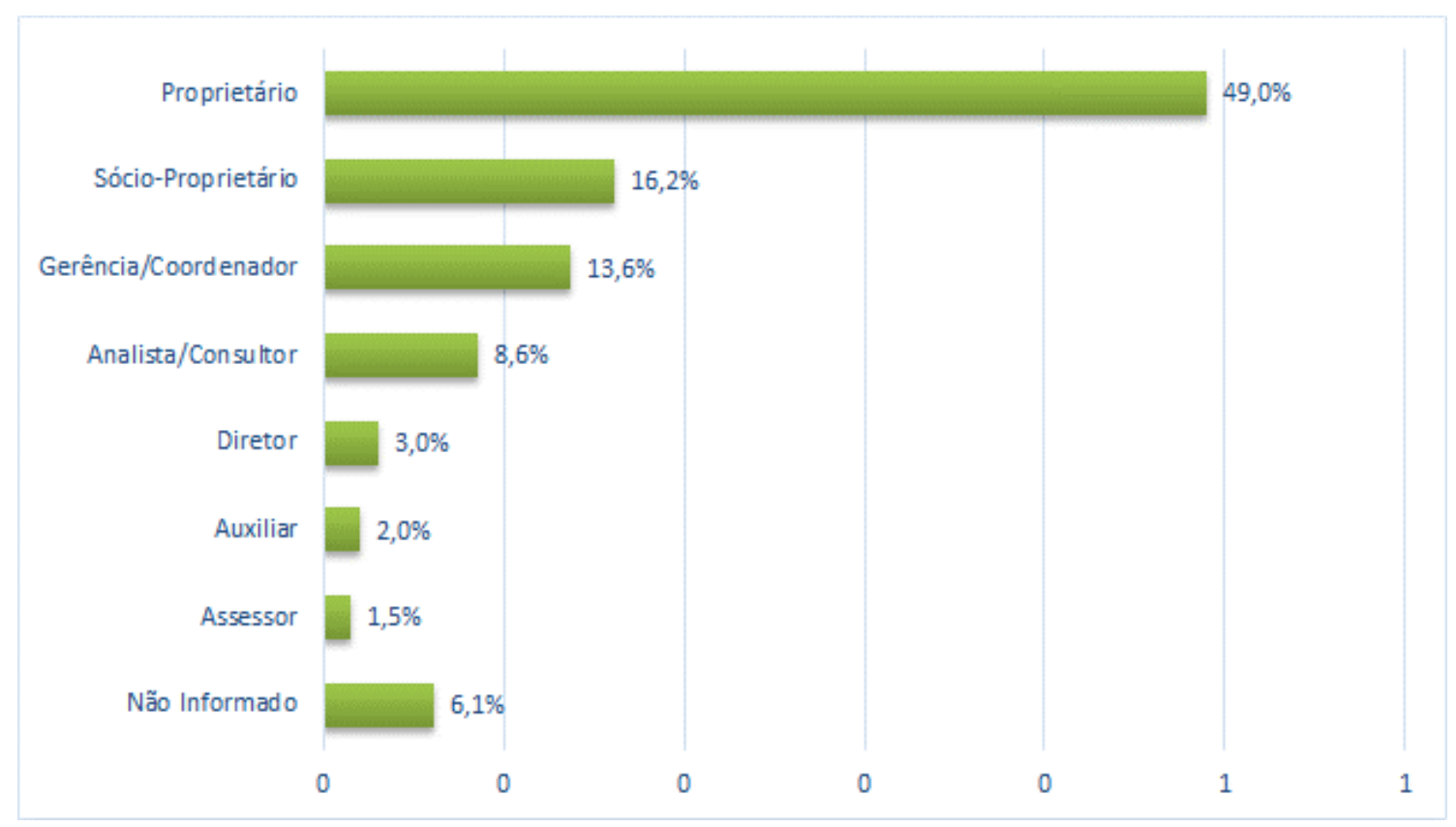

Figura 12 - Ocupação dos respondentes pelos empreendimentos rurais do estado de São Paulo

Nota. Fonte: elaboração da autora com base em ABRATURR, 2014

Esta situação parece apontar também para uma postura de compromisso direto com o negócio que poderia ser melhor esclarecida aplicando, por exemplo, as categorias de empreendedores de turismo rural identificadas por Oliveira (2001): aquele que reside na propriedade (autêntico), propriedade rural como segunda residência (sazonal) e os que não têm vínculos com o meio rural (investidor). Nesse sentido a indicação da existência de gerente, diretores, coordenadores e consultores parece confirmar que $16,6 \%$ destes empreendimentos têm uma gestão profissional.

O estudo de Geraldo (2012), traz mais algumas pistas de como estas relações podem se estabelecer, quando verifica que na sua área de estudo os proprietários indicam que desenvolvem atividades profissionais como industriais e empresários de outros setores, e também observa que:

Os proprietários mais jovens residem nas áreas urbanas das sedes municipais ou mesmo em outras localidades, além de haver os moradores em tempo parcial, residindo parte do tempo na propriedade e possuindo 
residências urbanas, semelhante ao que ocorria com os grandes produtores do período cafeeiro. (Geraldo, 2012, p.141)

No entanto será que esta é a realidade de todos os empreendimentos? Que diferença faz a presença permanente do proprietário no empreendimento? Esta parece ser uma situação diferente da detectada nos estudos europeus que indicam um fluxo de novos moradores para as zonas rurais. (Eusébio \& Figueiredo, 2008; Wanderley, 2001)

\subsection{Atividade de turismo rural}

\subsubsection{Distribuição espacial e inserção no turismo paulista}

Ao longo do percurso deste estudo verificaram-se várias iniciativas de pesquisadores, de entidades e associações e do poder público em mensurar e identificar alguns padrões de comportamento dos empreendimentos de turismo rural, no entanto sem alcançar resultados expressivos. Nesta mesma lógica propõem-se aqui um ensaio de justaposição de diferentes perspectivas, como o intuito de vislumbrar, no mínimo, quais as variáveis que deveriam ser consideradas essenciais para o aprofundamento de uma análise deste tipo.

Destaca-se o estudo de Pinho (2014) que, por meio de um criterioso processo de seleção de $\operatorname{amostra}^{24}$, identifica um conjunto de 87 municípios no Estado de São Paulo, configurado pela existência expressiva de empreendimentos de turismo rural ou pelo compromisso e interesse formalmente expressos no desenvolvimento deste segmento (Figura 13). Este

\footnotetext{
24 Pinho (2014, p.35) seleciona sua amostra a partir de dois critérios, sendo que o primeiro considera os municípios paulistas que indicaram o turismo rural como prioritário em seu Plano Municipal de Desenvolvimento Rural Sustentável - PMRS (2010-2013), e verifica que esta é uma situação presente em 43 dos 348 planos analisados. Como segundo critério considera os municípios que contam uma quantidade superior a 5 empreendimentos de turismo rural, e que estão indicadosno Guia de Turismo Rural (Roque, 2006), identificando um total de 44 localidades.
} 
recorte atende por um lado ao conceito de turismo rural formalmente estabelecido, e por outro permite uma leitura transversal a partir de informações obtidas em documentos específicos dos estudos rurais.

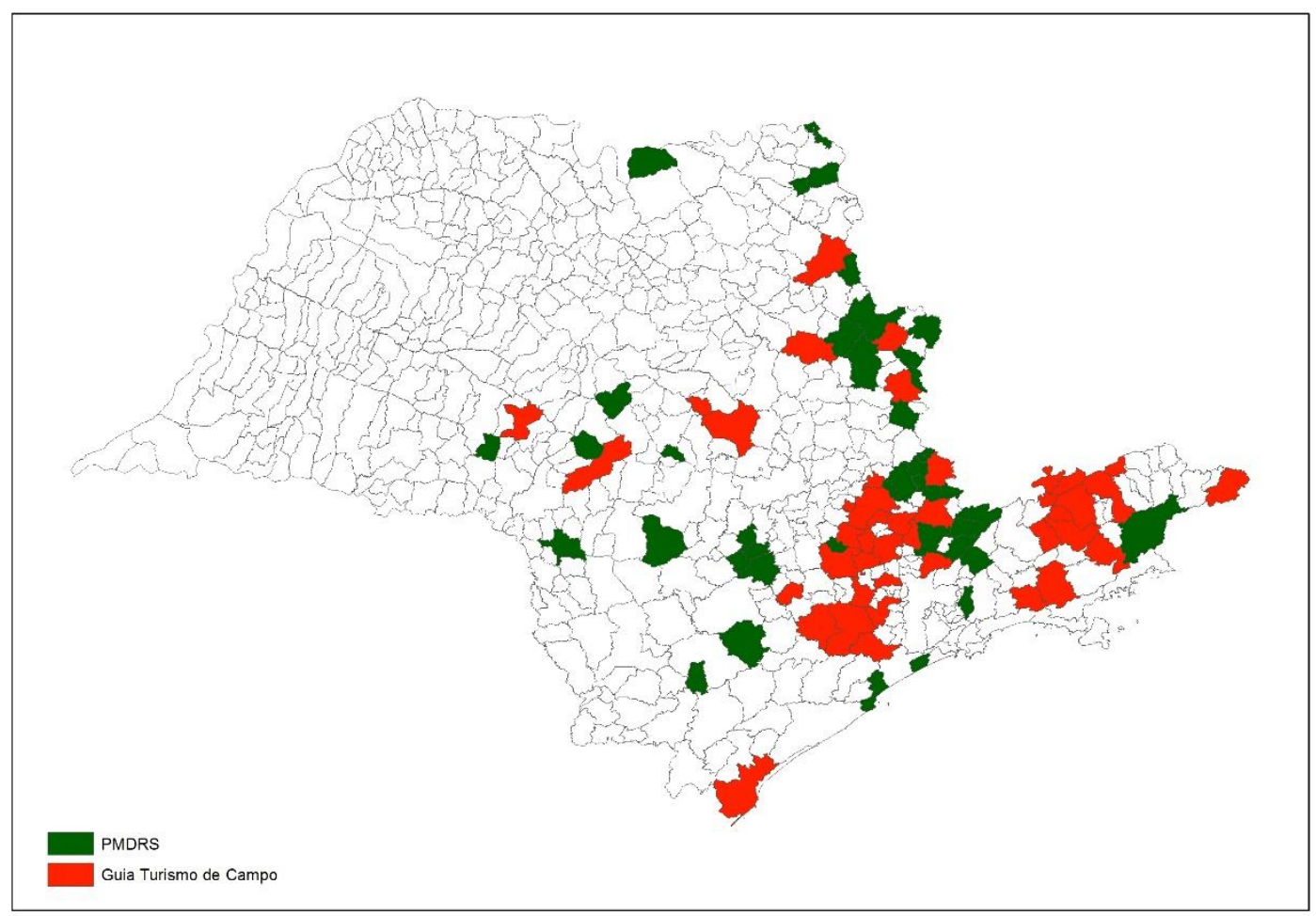

Figura 13 - Turismo rural nos municípios paulistas - 2014

Nota. Fonte: Elaboração da autora com base em dados de Pinho (2014, p. 35).

Como resultado tem-se um levantamento criterioso e atual do que pode ser a distribuição espacial dos empreendimentos de turismo rural no Estado. A partir dos dados de localização apresentados pelos empreendedores que participaram do levantamento da ABRATURR, em 2014, elaborou-se a Figura $14^{25}$, onde além de mostrar a distribuição destes empreendimentos no território paulista, também é possível observar as regiões e municípios onde estão concentrados (Anexo B).

${ }^{25}$ Refere-se a distribuição espacial de 198 empreendimentos de turismo rural. 
De modo geral, a distribuição espacial revelada nas duas figuras é bastante semelhante, exceto por alguns aspectos a serem destacados. Enquanto a Figura 13, abaixo mostra uma intensa concentração de empreendimentos nas regiões administrativas de São dos José dos Campos, Campinas e São José do Rio Preto, na Figura 14 se observa a mesma presença com uma concentração menor e ao mesmo tempo mais difusa no território, com destaque para a região de Ribeirão Preto, que não é mencionada na Figura 13.

Na Figura 14 observa-se que há apenas 5 municípios com mais de 10 empreendimentos, que são São Bento do Sapucaí (13), Mogi das Cruzes e Louveira (12 cada), São Roque e São João da Boa Vista (11 cada) e 2 municípios com 6 a 10 empreendimentos com proximidade geográfica a grandes centros urbanos, sendo que predominam os municípios com até 5 empreendimentos de turismo rural. Curiosamente a região que engloba os municípios do Circuito das Frutas parece não estar adequadamente representada neste levantamento.

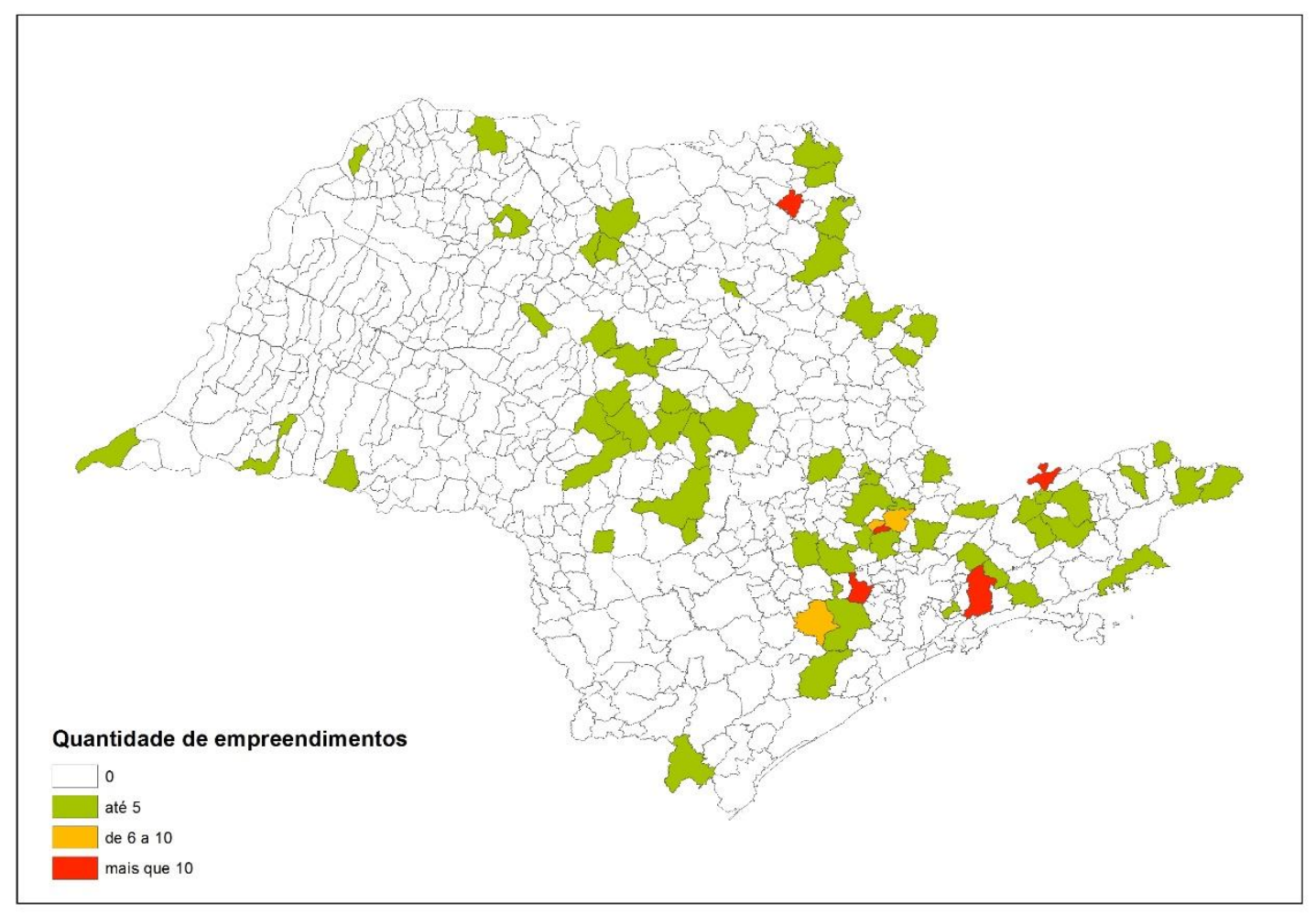

Figura 14 - Empreendimentos de turismo rural nos municípios paulistas - 2014 Nota. Fonte: elaboração da autora com base ABRATURR 2014 
Desta proposta de comparação emergem alguns questionamentos, que os próximos levantamentos deveriam considerar. Na Figura 13 os municípios destacados como PMDRS, podem estar ainda numa fase embrionária de desenvolvimento do turismo rural e, portanto, os seus empreendedores não foram detectados na pesquisa da ABRATURR. Ao mesmo pode se considerar que se tratam de municípios com forte interesse no desenvolvimento do segmento no futuro.

Por outro lado, se as listas de municípios que geraram as duas figuras fossem mescladas, terse-ia uma informação mais instigante, ao se perceber a presença de empreendimentos de turismo rural em maior ou menor escala em quase todo o território paulista, exceto na região do Oeste Paulista, que se caracteriza pela exploração intensiva do agronegócio, caracterizada como

[...] uma região bastante distante dos grandes centros emissores de turistas e que não dispõe de patrimônio histórico, cultura e/ou natural que seja suficiente para fomentar atividades turísticas. Os espaços rurais da região são marcados pela forte presença de latifúndios dedicados a pecuária de corte e, nos últimos anos, tem havido grande expansão da monocultura da cana-de-açúcar. (Hespanhol, 2013, p. 227)

Geraldo (2012), ao estudar algumas propriedades de turismo rural na região da Cuesta, também aponta esta característica da produção agrícola como um fator relevante na configuração da paisagem por vezes monótona da região. Curiosamente, também não foram indicadas propriedades de turismo rural na região Sul, onde se localiza uma extensa área de preservação ambiental, o PETAR - Parque Estadual Turístico do Alto Ribeira. Talvez a ausência de registro de atividade de turismo rural nesta região seja em função de uma forte articulação com o segmento de ecoturismo.

Os primeiros empreendimentos datam de 1990, e iniciaram suas atividades de "...de maneira tímida, desordenada e lenta, mas evoluindo constantemente, com a implantação gradativa de equipamentos de infra-estrutura, realização de adaptações voltadas para recepção de turistas” 
(Queiroz, 2012, p.29). O levantamento do Guia de Turismo Rural já salientava em 2006 a concentração desses empreendimentos nas regiões próximas a grandes centros urbanos, com uma distância de até $200 \mathrm{~km}$ (Roque, 2006, p. 168). Este padrão de distribuição dos empreendimentos também foi verificado por Bovo (2004) e Oliveira (2001).

Tabela 5 - Empreendimentos Rurais segundo região administrativa

\begin{tabular}{lcc}
\multicolumn{3}{c}{ Regiőes Administrativas } \\
\hline Campinas & Frequência & $\%$ \\
São José dos Campos & 63 & 31,8 \\
Sorocaba & 38 & 19,2 \\
Metropolitana de São Paulo & 31 & 15,7 \\
Bauru & 25 & 12,6 \\
Central (Araraquara e São Carlos) & 10 & 5,1 \\
São José do Rio Preto & 9 & 4,5 \\
Franca & 5 & 2,5 \\
Barretos & 4 & 2,0 \\
Ribeirão Preto & 4 & 2,0 \\
Presidente Prudente & 3 & 1,5 \\
Santos, São José dos Campos & 3 & 1,5 \\
Santos & 1 & 0,5 \\
Registro & 1 & 0,5 \\
Total & 1 & 0,5 \\
\hline
\end{tabular}

Nota. Fonte. Elaborado pela autora com base em dados de ABRATURR-2014

Este padrão verificado em diferentes estudos ainda se mantém, com destaque para os empreendimentos localizados nos municípios da Região Administrativa (RA) de Campinas (31,8\%), que abrange a área do Circuito das Frutas, seguido pela RA de São José dos Campos (19,2\%), que abarca uma ampla área do Vale do Paraíba, RA de Sorocaba (15,7\%) e Região Metropolitana de São Paulo (12,6\%). O restante encontra-se distribuído entre sete RAs do Centro-Oeste $(19,1 \%)$. 


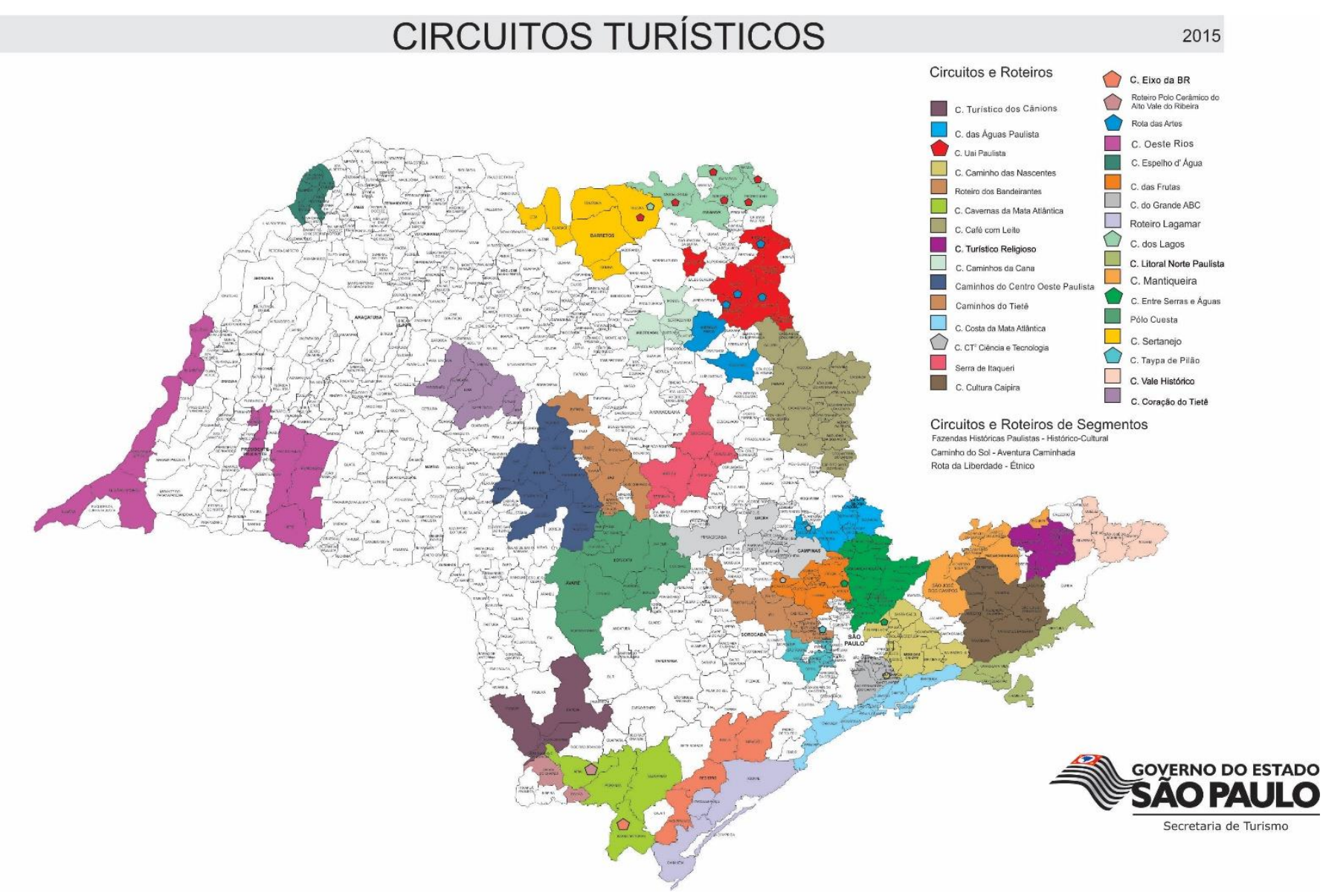

Figura 15 - Circuitos e Roteiros Turísticos do Estado de São Paulo

Nota. Fonte: Secretaria de Turismo (2015)ํ․

Desde 2003, o Ministério do Turismo tem implementado uma série de ações no sentido de estimular o poder público estadual a planejar e articular o desenvolvimento do turismo numa perspectiva regional. No Estado de São Paulo este processo tem sido discutido desde então, e várias iniciativas de organização regional têm sido propostas, como os Circuitos e Roteiros Turísticos temáticos representados na Figura 15.

A presença dos empreendimentos de turismo rural nestes Circuitos pode ser um indicativo de maior proximidade com outras atividades turísticas ofertadas na região em que estão localizados. Como pode ser observado na Figura 15, os Circuitos e Roteiros estão distribuídos em vários regiões do Estado, e congregam principalmente conjuntos de municípios que nem sempre conseguem fazer um trabalho de articulação eficiente. Deste 
grande conjunto foram indicados 7 Circuitos com destaque para os seguintes: a) Circuito das Frutas (16,7\%), que congrega vários municípios da RA de Campinas com atuação no turismo rural há um longo período e, portanto, considerado um produto de turismo consolidado (Roque, 2016) e, como tal, objeto de estudos de Gonçalves (2004) e Bernardi (2009). Em seguida está o Circuito da Mantiqueira (12,1\%), na RA de São José dos Campos, no qual estão inseridos destinos turísticos consolidados como Campos do Jordão.

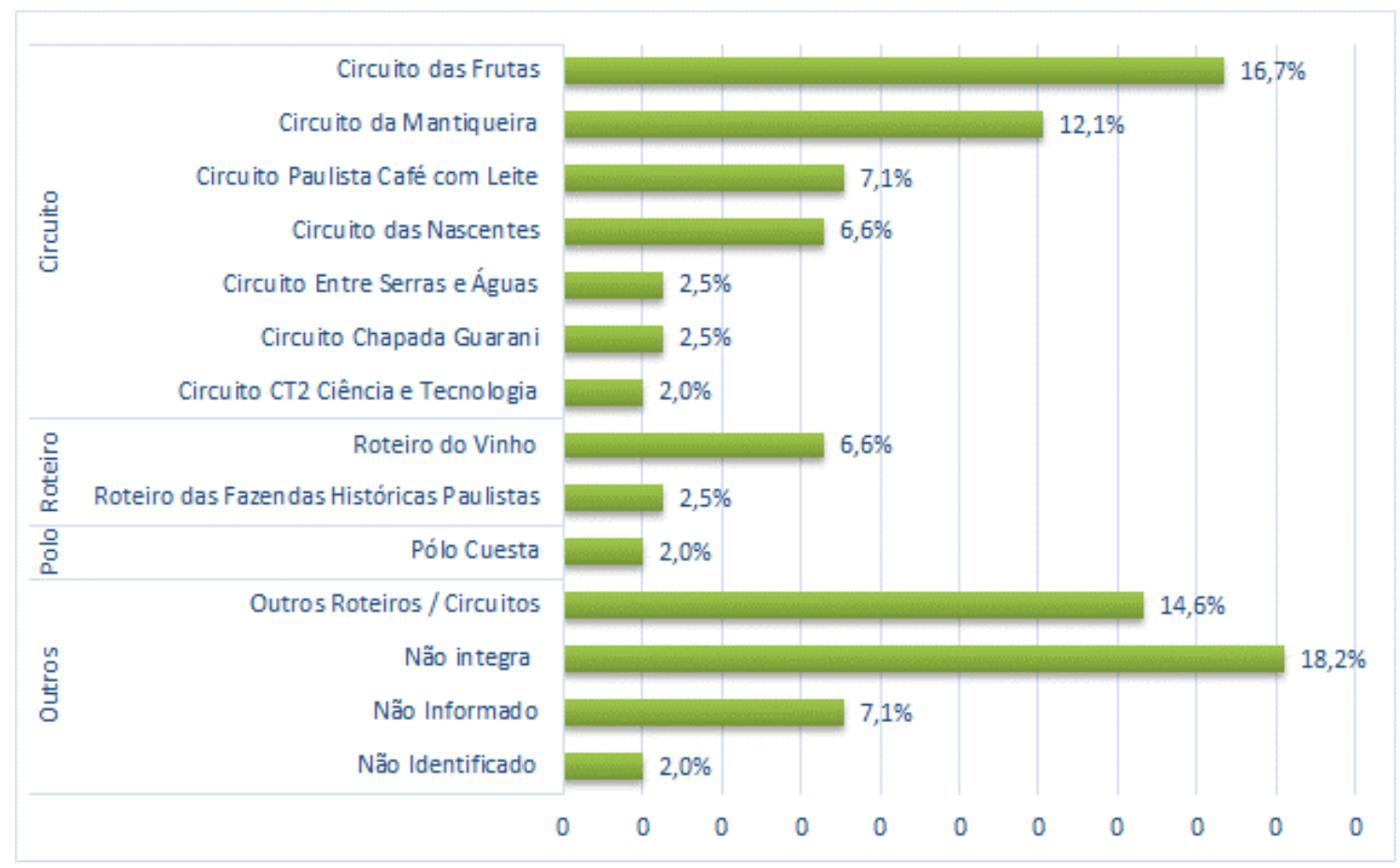

Figura 16 - Empreendimentos inseridos nos Circuitos e Roteiros do Estado de São Paulo

Nota. Fonte: Elaborado pela autora com base em dados de ABRATURR - 2014

Depois destes destaques, são indicados o Circuito Paulista Café com Leite (7,1\%), que congrega vários municípios da região de Mococa, com longa experiência em turismo rural e também já consolidado (Roque, 2016); o Circuito das Nascentes (6,6\%), que tem atuação recente no turismo rural, mas articulada e estratégica ${ }^{26}$; os Circuitos Entre Serra e Águas

\footnotetext{
${ }^{26}$ Em 2015, os alunos da disciplina de Planejamento e Organização do Turismo, da ECA/USP, realizaram um levantamento e um diagnóstico aprofundado do turismo de Mogi das Cruzes, identificando o turismo rural como um dos segmentos de maior expansão no município.
} 
(2,5\%) e Guarani (2,5\%); e por fim o de Ciência e Tecnologia de Campinas $(2,0 \%)$ com pouca expressão no conjunto.

Além dos circuitos são indicados dois roteiros, o dos Vinhos (6,6\%), na região de São Roque, com atuação reconhecida e consolidada no turismo rural, e o das Fazendas Históricas Paulistas (2,5\%). Este último, embora esteja indicado como roteiro não existe como tal, mas sim na forma de uma associação que reúne alguns proprietários de fazendas histórias. Por fim tem-se o Pólo Cuesta, na região de Botucatu. Vale ressaltar que 18,2 \% dos empreendimentos não integram nenhum tipo de circuito ou roteiro.

\subsubsection{Atrativos e diferenciais}

Ao serem inquiridos acerca dos recursos ou atrativos de suas propriedades os empreendedores destacam predominantemente aqueles que têm relação com o meio ambiente natural, ressaltando a presença de locais que podem promover uma maior aproximação da natureza, como trilha para caminhada (35,9\%), área de proteção ambiental $(11,1 \%)$ gruta e/ou caverna (5,1\%), superfícies líquidas com possibilidade de realização de atividades de lazer como rio, lago e represa $(20,7 \%)$, banhos em cachoeira $(14,1 \%)$, piscina natural $(4,5 \%)$ ou praia $(1,5 \%)$, e mirantes para contemplação $(11,1 \%)$. (Tabela 7$)$ 


\section{Tabela 6 - Empreendimentos de turismo rural no Estado de São Paulo segundo atrativos}

turísticos

\begin{tabular}{|c|c|c|}
\hline Tipos de Atrativos & Atrativos & $\%$ \\
\hline \multirow{8}{*}{ Naturais } & Trilha para caminhada & 35,9 \\
\hline & Rio, Lago e Represa (açude, barragem, etc) & 20,7 \\
\hline & Cachoeira & 14,1 \\
\hline & Área de Proteção Ambiental (APA) & 11,1 \\
\hline & Mirante & 11,1 \\
\hline & Gruta e/ou caverna & 5,1 \\
\hline & Piscina Natural & 4,5 \\
\hline & Praia (maritima, fluvial ou lacustre) & 1,5 \\
\hline \multirow{3}{*}{ Rurais } & Horta & 31,8 \\
\hline & Pomar & 24,7 \\
\hline & Criação de Animais/Aves & 2,0 \\
\hline \multirow{3}{*}{ Culturais } & Museu & 1,5 \\
\hline & Construção de valor histórico (casarão, senzala, capela e ou similar) & 13,1 \\
\hline & Ruínas de valor histórico & 4,5 \\
\hline Naturais & Turismo de Aventura & 0,5 \\
\hline & Outros & 1,5 \\
\hline & Não Informado & 6,6 \\
\hline
\end{tabular}

Nota.Fonte: Elaboração da autora com base em dados de ABRATURR - 2014

Em segundo lugar são indicados os atrativos relacionados às práticas agrícolas, distribuídos em: Horta (31,8\%), Pomar (24,7\%) e Criação de Animais/Aves (2,0\%). Apesar de vários pesquisadores apontarem o turismo rural como estratégia de preservação do patrimônio material e imaterial, isto é pouco percebido pelos empreendedores como um atrativo ou recurso significativo, pois apenas $13,1 \%$ dos empreendimentos possuem construção de valor histórico (casarão, senzala, capela e ou similar), além de ruínas de valor histórico (4,5\%) e museu $(1,5 \%)$.

Sobre esta questão vale ressaltar que o entendimento que restringe patrimônio apenas ao que é edificado estava expresso nas possibilidades de resposta no próprio formulário, e que acaba por restringir a possibilidade de uma análise mais apurada da realidade. Principalmente, se considerar que além do consumo da paisagem e da natureza revelado pelo expressivo número de indicações, as propriedades rurais também têm se apoiado na oferta gastronômica como diferencial deste tipo de negócio, como destaca Carvalho (2012, p.52): “Um símbolo bastante 
característico da hospitalidade rural é a oferta gastronômica de produtos caseiros e artesanais como doces, bolos, chás, café, biscoitos, sucos naturais, entre outros”.

Mas os atrativos e recursos são apenas o que é tangível? Como mensurar ou valorizar o intangível que normalmente é fundamental na construção de uma experiência de viagem? Oliveira (2001) oferece algumas pistas e aponta para questões importantes ao afirmar que o “turismo rural está associado ao chame, à proximidade e a simpatia do povo brasileiro, porém maximiza o estereótipo do caipira ingênuo e acolhedor" (p. 52).

Por um lado, os aspectos positivos associados ao mundo rural têm sido apropriados exemplarmente por alguns empreendimentos, como as Fazendas Capoava (Itu) e Águas Claras (Itapira), que com essa abordagem de negócio conseguiram se inserir no catálogo da Associação de Hotéis Roteiro de Charme. Por outro, a abordagem simplista de explorar o estereótipo deste caipira paulista, que para muitos carrega ainda a imagem negativa do campo, associados a pobreza e ao atraso ${ }^{27}$. Essa é uma questão que precisa ser entendida e superada com sensibilidade, perspicácia e criatividade, como aponta Mazuel (2000):

Os agricultores que praticam o acolhimento na fazenda encontram respostas adaptadas. Para evitar a folclorização saudosista, eles criam um ambiente - museu em que evocam os velhos documentos, instrumentos antigos, vídeos, as práticas camponeses antigas. Depois eles dirigem o pequeno grupo de turistas para a propriedade moderna, mostrando a evolução, a vida e as pressões sobre os agricultores atualmente. Trata-se o turista como um adulto, capaz de discernimento. Não se procura vender a ele, a qualquer preço, uma imagem arcaica do campo. (p. 108)

Uma discussão séria e aprofundada sobre a diferença entre atrativo e recurso pode contribuir para que estes empreendedores se sensibilizem e comecem a perceber o que pode ser atrativo para os seus visitantes, e então terão os elementos fundamentais para a composição de um portfólio de produtos e serviços que possa representar o que têm de melhor. Não se trata

\footnotetext{
${ }^{27}$ Esta questão é discutida de forma primorosa por Brandão na obra Os caipiras de São Paulo. Brandão (1983).
} 
apenas de uma preocupação com comercialização, diferencial ou marketing, mas sim de autoestima e valorização do que é rural.

Em 2001, Oliveira (2001) já salientava que os empreendedores deveriam considerar a mudança no perfil dos visitantes e de seus interesses, "cada vez mais interessados em obter informações sobre a propriedade, as diferentes culturas agrozootécnicas, formas de manejo, a história e a cultura local etc.” (p. 58). Observa-se que esse levantamento não indicou nenhuma inovação neste sentido, com o que se pergunta: Será que não existem? Ou, de novo, os empreendedores não percebem que o seu saber fazer é o diferencial? Onde estão os produtores de orgânicos tão na moda? E as formas de manejo alternativas?

Tabela 7 - Empreendimentos de turismo rural no Estado de São Paulo segundo tipos de atividades desenvolvidas - 2014

\begin{tabular}{|c|c|c|}
\hline Tipos de Atividade & Atividades & $\%$ \\
\hline \multirow{3}{*}{ Criação de animais } & Hípica/ Cavalgadas & 6,1 \\
\hline & Pesqueiro & 4,5 \\
\hline & Apiário & 1,0 \\
\hline \multirow{8}{*}{ Agricultura } & Vinícola & 7,1 \\
\hline & Alambique & 4,5 \\
\hline & Colhe e pague & 4,0 \\
\hline & Mostrar a Produção & 4,0 \\
\hline & Leiteria e Queijeria & 2,0 \\
\hline & Orquidário & 2,0 \\
\hline & Produtos Orgânicos & 1,5 \\
\hline & Comércio de Plantas & 1,0 \\
\hline \multirow{4}{*}{ Produção artesanal } & Artesanato & 3,0 \\
\hline & Venda de Produtos Artesanais & 1,5 \\
\hline & Pães Artesanais & 1,0 \\
\hline & Produção de Doces & 1,0 \\
\hline \multirow{7}{*}{ Serviços Turísticos } & Hospedagem & 26,8 \\
\hline & Restaurante Rural & 25,8 \\
\hline & Day Use & 13,1 \\
\hline & Café Rural & 3,0 \\
\hline & Camping & 1,5 \\
\hline & Bar & 0,5 \\
\hline & Pizzaria Rural & 0,5 \\
\hline Culturais & Visitação Histórico Cultural & 2,0 \\
\hline \multirow{6}{*}{ Turismo de Aventura } & Trilha Ecológica & 13,6 \\
\hline & Paraquedismo & 0,5 \\
\hline & Paintball & 0,5 \\
\hline & Turismo de Aventura & 0,5 \\
\hline & Buggy & 0,5 \\
\hline & Rapel & 0,5 \\
\hline Turismo Pedagógico & Turismo Pedagógico & 1,5 \\
\hline Turismo de Negócios & Turismo de Negócios & 0,5 \\
\hline Outros & Outros & 3,0 \\
\hline
\end{tabular}

Nota. Fonte: Elaboração da autora com base em dados de ABRATURR - 2014. 
A partir de um rol de atividades preparado com base em conhecimento técnico do pessoal da ABRATURR e do formulário utilizado para o Guia de Turismo Rural (Roque, 2006), buscou-se identificar quais eram as atividades mais comuns ofertadas nos empreendimentos de turismo rural paulista. Para facilitar a análise as respostas foram organizadas em 11 categorias considerando aspectos comuns das inúmeras atividades indicadas no formulário (Tabela 8).

Verifica-se que a hospedagem $(26,8 \%)$ e o restaurante rural $(25,8 \%)$ destacam-se entre os serviços ofertados nas propriedades, que são serviços turísticos per si e podem estar combinados ou não com a oferta de outras atividades de lazer. Estes serviços juntamente com a possibilidade de day use (13,1\%), camping (1,5\%), café rural (3,0\%), bar e pizzaria rural $(0,5 \%)$ são essencialmente de caráter turístico, e poderiam ter sido contemplados no formulário com um item exclusivo que permitisse avaliar as características específicas como capacidade e diferencial de serviços.

As outras categorias contemplam a oferta de uma série de atividades de lazer e de comercialização de produtos diretamente relacionados a aspectos da vida no campo e da sua produção. $\mathrm{Na}$ categoria denominada agricultura foram indicadas atividades relacionadas à produção, como a vinícola $(7,1 \%)$, o alambique (4,5\%), a leiteria/queijaria e o orquidário, com $2,0 \%$ cada uma, além de produtos orgânicos $(1,5 \%)$ e comércio de plantas $(1,0 \%)$. Também nesta categoria foram indicadas duas atividades que permitem maior interação dos visitantes com a prática agrícola: o colhe e pague e a mostra da produção $(4,0 \%)$, e outras ligadas à produção e comercialização de pães e doces artesanais $(2,0 \%)$ e ao artesanato $(4,5 \%)$. 
Como atividades de lazer relacionadas à criação de animais se destacam o hipismo/cavalgadas ${ }^{28}(6,1 \%)$, o pesqueiro $(4,5 \%)$ e o apiário (1\%); e foi apontada uma única atividade com cunho histórico-cultural (2,0\%).

Curiosamente os empreendedores indicaram algumas modalidades de turismo como atividades, por exemplo Turismo de Aventura, que contempla uma série de atividades de lazer na natureza como as trilhas ecológicas (13,6\%), e outras como buggy, paraquedismo, paintball e rapel, além de turismo pedagógico e de negócios.

Verifica-se que as atividades propostas no formulário refletem a percepção da prática cotidiana do turismo rural, e pouco incorpora os conceitos e o suporte metodológico desenvolvido pelos investigadores de turismo para elaboração de inventários de oferta turística por exemplo. Isto pode ser um dos muitos reflexos das fragilidades conceituais apontadas nas discussões sobre o segmento, juntamente com a dificuldade de encontrar profissionais de planejamento turístico atuando junto à área. Ou, ainda, o distanciamento entre a academia e a realidade turística, que precisa ser solucionada a partir de uma maior aproximação entre ambas.

Assim como comentado anteriormente, a percepção limitada e superficial sobre o que é atrativo ou não se reflete também na oferta de atividades, seja de lazer, seja de comercialização de produtos artesanais. Talvez a estratégia de formulação das questões tenha limitado o levantamento de dados mais claros sobre esta realidade, mas alguns pesquisadores que trabalharam com diferentes experiências de turismo rural no Estado apontam para uma problemática que emerge com frequência, como relata Gonçalves (2004) em sua avaliação sobre os produtos turísticos do Circuito das Frutas:

\footnotetext{
${ }^{28}$ É uma modalidade de atividade de turismo rural explorada apenas em algumas propriedades, em decorrência dos custos e da logística necessária para se manter uma criação de animais. Com o intuito de compreender um pouco desse universo, Luques (2014) realizou uma análise exploratória sobre o turismo equestre no Estado de São Paulo.
} 
Observou-se, durante as visitas realizadas que o processo de adequação ao serviço turístico pretendido, resultou em um empreendimento apenas localizado no meio rural, sem comprometimento algum com questões como identidade e autenticidade que norteiam o turismo rural. (p. 125)

Não é possível saber a frequência com esta situação está ocorrendo, mas existem sinalizações de que o cotidiano e a necessidade de atender às demandas dos visitantes muitas vezes podem compelir os empreendedores a se renderem exclusivamente à lógica do mercado. Ao mesmo tempo, muitos deles têm clareza que o diferencial de seu negócio está em oferecer exatamente o que estes turistas não têm em seu cotidiano.

Carvalho (2012) verifica como este dilema está bem resolvido em propriedades que têm bem definido seu produto e sua demanda, e percebe que:

[...] o turismo rural, através da ressignificação do lugar e da paisagem, se apropria dos simbolismos da hospitalidade para então gerar um produto/mercadoria que atenda às necessidades físicas e psicológicas dos visitantes, pautando, dessa forma, algumas tendências nesse meio rural, no interior do estado de São Paulo. (p. 125)

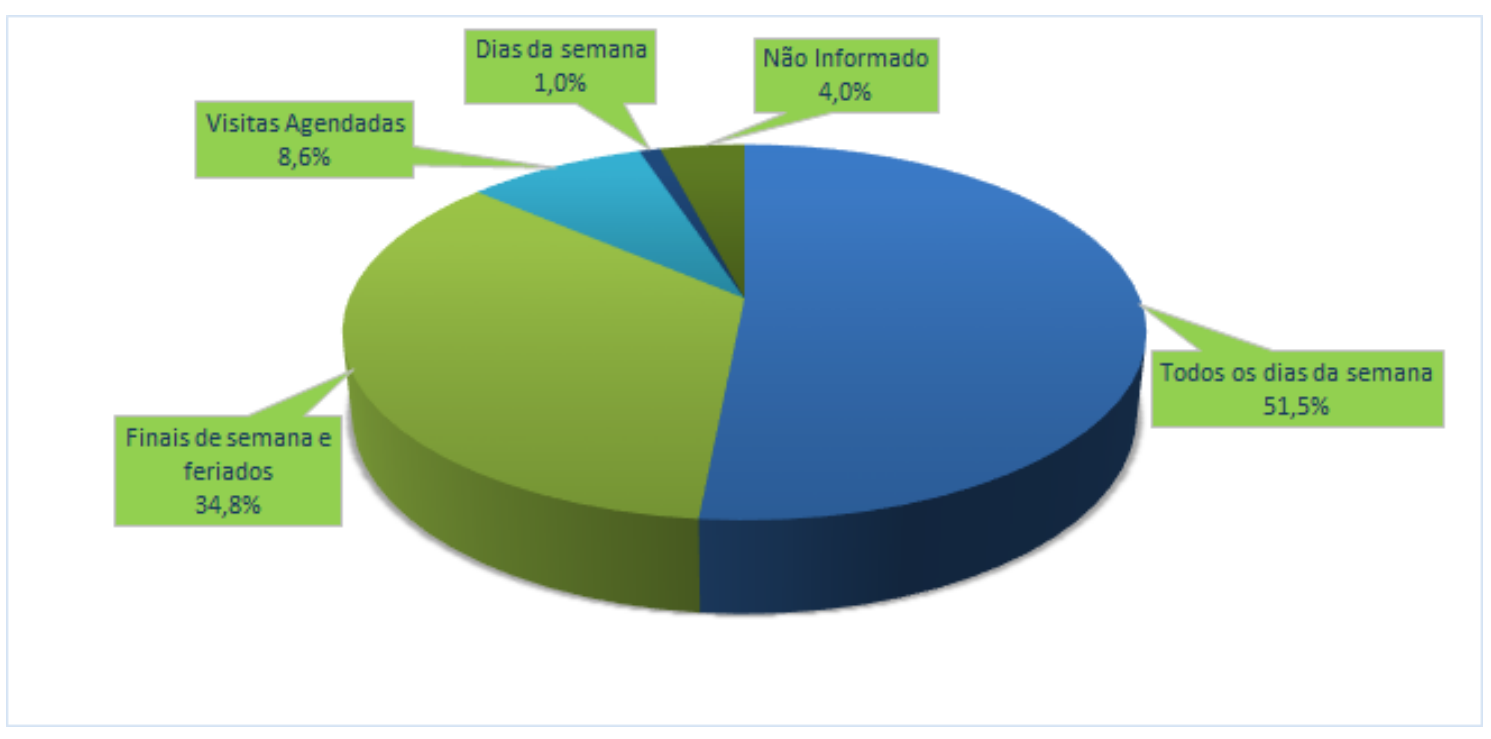

Figura 17 - Empreendimentos de turismo rural segundo funcionamento ao público - ano

Nota. Fonte: Elaboração da autora com base ABRATURR - 2014. 
Oliveira (2004), ao discutir acerca do perfil dos empreendedores de turismo rural destacava que uma das questões relevantes, que precisa ser considerada no momento da decisão por investir nessa modalidade de atividade, estava relacionada às peculiaridades do turismo, como a disponibilidade de tempo e a perda da privacidade.

Os resultados do questionamento acerca da disponibilidade destas propriedades para atendimento aos visitantes mostram uma situação que pode se tornar preocupante, pois $51,5 \%$ dos entrevistados afirmam que atendem o público todos os dias da semana e 34,8\% nos finais de semana e feriados. Apenas em algumas propriedades há uma grande restrição de disponibilidade de atendimento, e só atendem com agendamento $(8,6 \%)$; e poucas atendem somente durante a semana $(1,0 \%)$. Certamente estas situações mais restritivas se relacionam com produtos ou serviços muito específicos.

\subsection{Estrutura do negócio}

\subsubsection{Tempo de atuação}

As pesquisas sobre o perfil do empreendedor de turismo rural realizadas pelo SEBRAE (2013) e por Roque (2012) apontam para um cenário em que os negócios com mais de 10 anos de atuação na área eram predominantes, detectando inclusive alguns com mais de 20 anos, um indicador de longevidade dos empreendimentos de turismo rural analisados. Em seguida apareciam os que tinham entre 5 e 10 anos de operação e os com menos de 5 anos. Essa diversidade de tempos de atuação também é verificada nos empreendimentos de turismo rural paulista, como pode ser observado na Tabela 6 . 
Tabela 8 - Empreendimentos de turismo rural no Estado de São Paulo segundo tempo de atuação na atividade

\begin{tabular}{|ccc|}
\hline \multicolumn{3}{c|}{ Tempo das Atividades de Turismo Rural } \\
\hline Tempo & Frequência & $\%$ \\
\hline Até 1 ano 1 ano e 1 mês - 2 anos & 22 & 11,1 \\
De 2 anos e 1 mês - 3 anos & 17 & 8,6 \\
De 3 anos e 1 mês - 5 anos & 16 & 8,1 \\
De 5 anos e 1 mês - 8 anos & 20 & 10,1 \\
De 8 anos e 1 mês - 10 anos & 21 & 10,6 \\
Mais de 10 anos e 1 mês & 21 & 10,6 \\
Estruturando-se para a atividade & 71 & 35,9 \\
Não Informado & 1 & 0,5 \\
Total & 9 & 4,5 \\
\hline
\end{tabular}

Nota.Fonte: Elaboração da autora com base em dados de ABRATURR - 2014

Se considerar as mesmas categorias temporais indicadas acima, observa-se uma distribuição semelhante. No entanto vale ressaltar a quantidade expressiva de negócios nos seus primeiros anos de existência, de 1 a 3 anos com quase 27,8\% dos empreendimentos. Embora não seja possível depreender em que momento do ciclo de vida organizacional se encontram, pois o único dado disponível é o tempo, pode-se inferir que a maior parte dos empreendimentos já podem estar consolidados ou em vias de, o que significa que superaram as dificuldades de implantação e o momento crucial da sobrevivência do negócio. Os responsáveis por elaborar e implementar políticas e ações para o aprimoramento da gestão destes negócios deverão considerar as demandas específicas de cada estágio de desenvolvimento, uma vez que não é mais possível somente ofertar capacitação e treinamento com vistas a fomentar a implementação de novos negócios.

\subsubsection{Trabalhadores}

A recente aprovação da Lei do Turismo Rural, respondeu a uma das inúmeras demandas do segmento, relacionada à facilitação das questões trabalhistas nestes empreendimentos, mas 
outras demandas, inclusive aquelas relacionas à bitributação de unidades produtivas rurais que também atuam como prestadoras de serviços turísticos, ainda está pendente.

Uma das principais dificuldades para defender a importância das solicitações contempladas no projeto de lei era, e ainda é, a ausência de dados sobre a dimensão dos negócios de turismo rural no país, principalmente aquela relacionada aos impactos que geram emprego e renda nas áreas rurais. Então além de até recentemente as atividades de turismo rural não serem identificadas pelas pesquisas realizadas sobre as UPAs - Unidades Produtivas Agropecuárias, também não tinham condições de se formalizar como prestadores de serviços turísticos.

Em relação à situação de formalização do negócio (Figura 18), verificou-se que 67,2\% dos empreendimentos possuem algum tipo de registro junto a órgãos públicos (federal, estadual e municipal) e $1,5 \%$ está em vias de registro. Isso demonstra que existe interesse dos empreendedores em serem legalizados. A formalização de empreendimentos traz vantagens significativas para a operação cotidiana, no diz que respeito a impostos e principalmente à contratação de empregados.

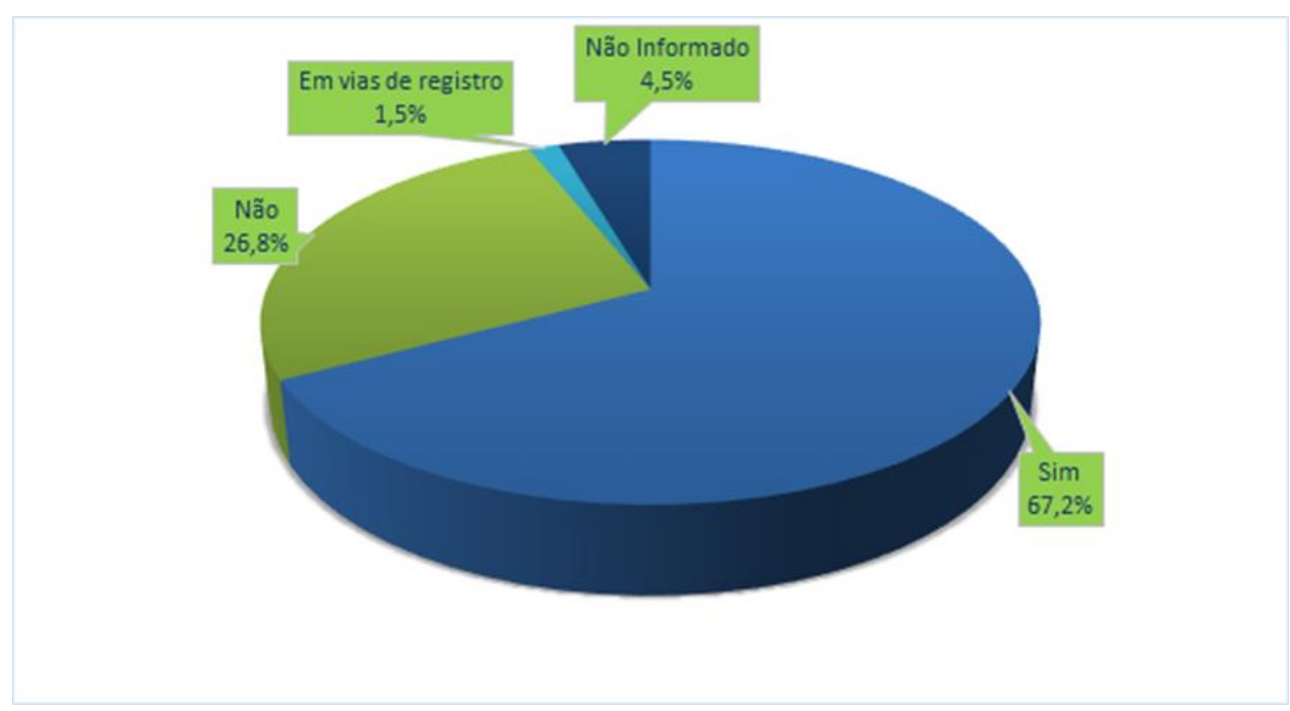

Figura 18 - Empreendimentos formalizados junto a órgãos públicos

Nota. Fonte: Elaboração da autora com base ABRATURR - 2014. 
Os empreendimentos de turismo rural são na sua maioria negócios familiares $(82,3 \%)$ e, portanto, têm baixa capacidade de gerar emprego (Figura 20). Normalmente são 2 a 5 pessoas (52,5\%) cuidando do negócio cotidianamente, mas como existem diferentes modalidades de empreendimentos também é possível encontrar propriedades de médio porte com 6 a 10 pessoas $(18,7 \%)$ e aquelas que empregam mais de 11 pessoas $(21,2 \%)$. (Figura 19)

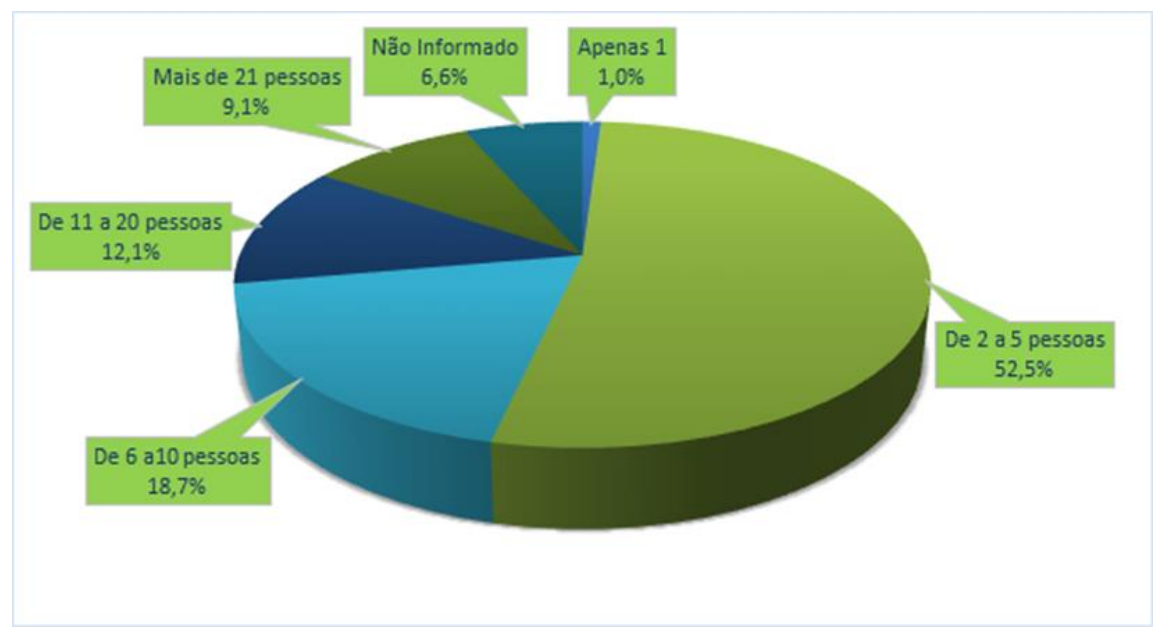

Figura 19 - Quantidade de trabalhadores e participação dos familiares nos empreendimentos de turismo rural no Estado de São Paulo

Nota. Fonte: Elaboração da autora com base ABRATURR - 2014.

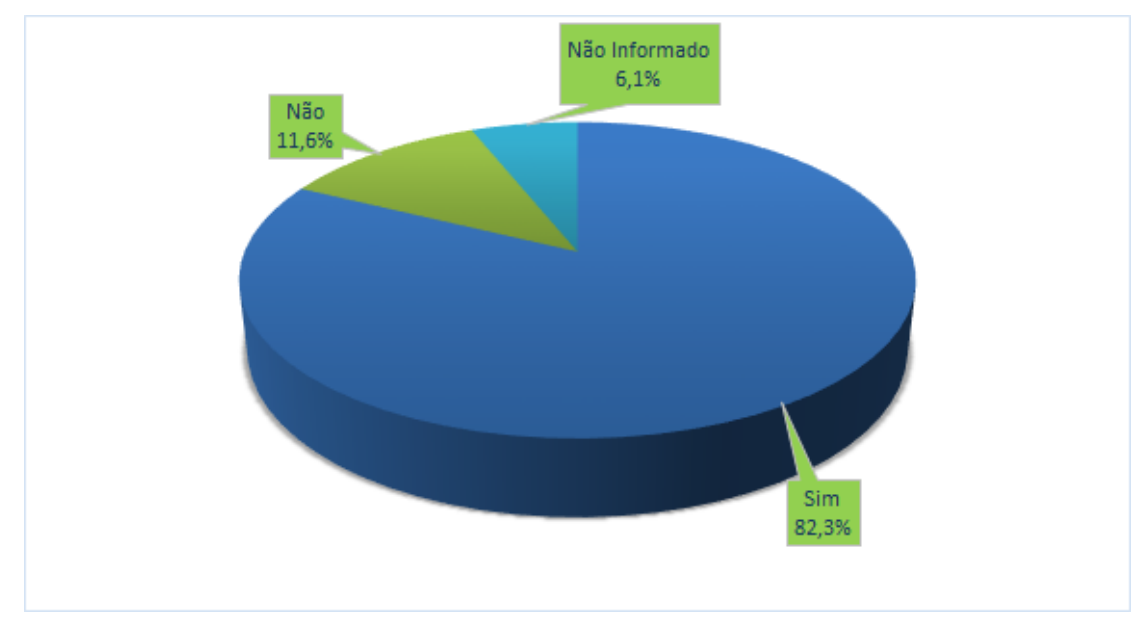

Figura 20 - Auxílio dos familiares nos empreendimentos de turismo rural no Estado de São Paulo

Nota. Fonte: Elaboração da autora com base ABRATURR - 2014 


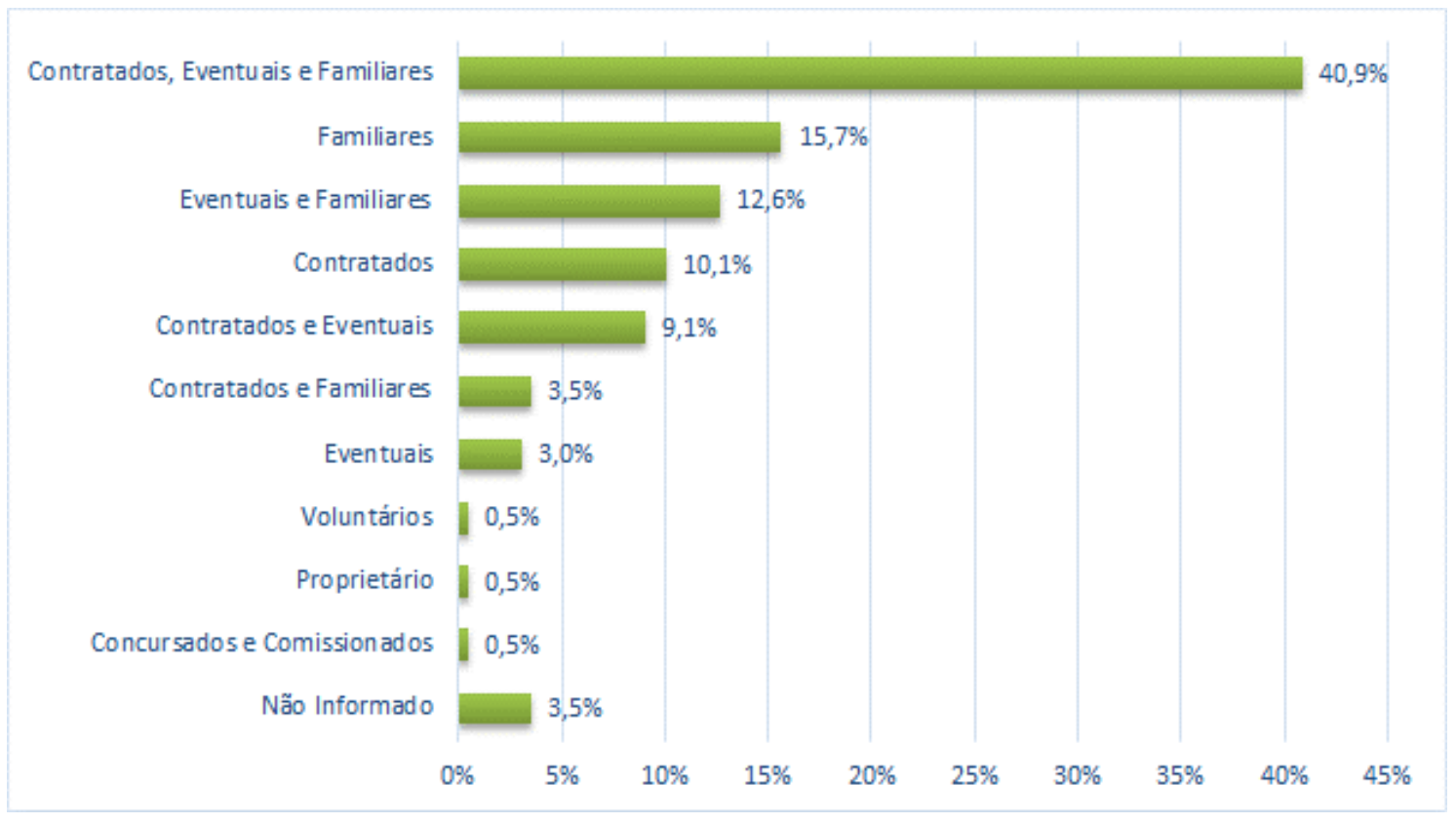

Figura 21 - Empreendimento segundo situação dos trabalhadores

Nota. Fonte: Elaboração da autora com base ABRATURR - 2014

De modo geral as propriedades apesar de familiares contam com o apoio de empregados que são contratados de forma permanente $(10,1 \%)$, eventual $(3,0 \%)$ e, na maioria das vezes com o suporte de trabalhadores com diferentes formas de contrato de serviços, trabalhando juntamente com a família (40,9\%). Esta situação complexa e diversa está intrinsecamente relacionada à formalização do empreendimento e às restrições de contratação quando é reconhecido formalmente apenas como unidade produtiva rural. Esta situação poderia ser amplamente explorada em investigações e estudos sobre a questão do trabalho, da geração de renda e da economia nestes empreendimentos rurais-turísticos.

\subsubsection{Práticas agrícolas}

Uma das premissas para ser considerado um empreendimento de turismo rural é que tenha algum tipo de comprometimento com a produção agropecuária. Contudo, a legislação brasileira ainda não contempla a diversidade de atividades não agrícolas que fazem parte da 
rotina destas unidades produtivas rurais. Mas difícil ainda é considerar que, além da tradicional produção agrícola, também possam oferecer uma série de serviços de lazer e turismo de modo profissional. De fato, não se trata somente de buscar a atualização das leis brasileiras em adequação ao novo cenário, mas de um grande desafio para estes proprietários que ousam atuar em atividades tão diversas do que seria as de sua natureza.

Apesar destes fatores, $69,7 \%$ dos empreendimentos paulistas têm a prática agrícola em seu cotidiano, enquanto 27,3\% disseram que não (Figura 22). Trata-se de um registro insólito, uma vez que ao convidar as pessoas para o preenchimento do formulário foi informado que se tratava de turismo rural e considerando o conceito do Ministério do Turismo. Isto pode ser uma sinalização dos empreendedores que mesmo não contando com a presença da prática agrícola em seu cotidiano se consideram um empreendimento de turismo rural.

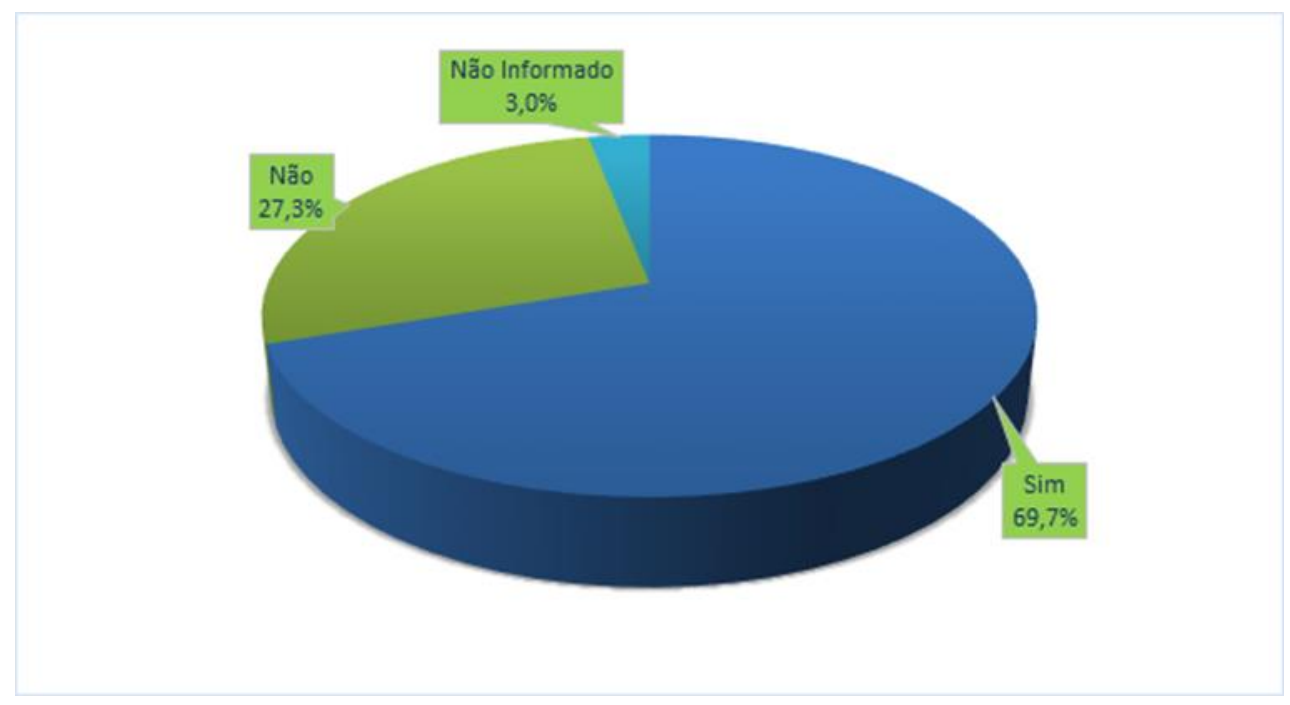

Figura 22 - Práticas Agrícolas no Empreendimento de turismo rural

Nota. Fonte: Elaboração da autora com base ABRATURR - 2014

Outra questão que é apontada com frequência na literatura é a possibilidade de que estas propriedades agrícolas se transformem integralmente em negócios turísticos, porque os rendimentos advindos do turismo podem superar em muito aqueles recebidos pela produção agrícola. Mas, como salienta Geraldo (2012), 
A manutenção de produção primária, além de seu valor inerente e apesar de não ser o maior fator gerador de rendimentos, contribui também como fator de atratividade, pois a existência de uma "vida rural" na propriedade é de grande importância para o produto turístico comercializado. Ainda que possa ter certo aspecto "cenográfico", sem implicações diretas relevantes na vida econômica da propriedade, um empreendimento turístico em meio rural deve contar com aspectos agrícolas e criatórios, para a satisfação das expectativas dos hóspedes, além de atender às necessidades do próprio estabelecimento, como o fornecimento de alimentos ou animais para passeios e cavalgadas, por exemplo. (p. 136)

Serão os empreendimentos de turismo rural uma grande farsa? Manter a produção agrícola apenas porque garante o ambiente rural é equivocado? Estas indagações nos levam a pensar seriamente na colocação de Mazuel (2000) que sugere ao empreendedor ser honesto com os turistas, já que a realidade rural assim como a urbana é muito dinâmica, e manter um rural que não existe mais pode ser apenas hipocrisia. Carvalho (2012) se depara com esta situação de inexistência da prática agrícola na Fazenda Capoava e verifica que isso não é um problema para os turistas. Mas seria para o turismo rural? Para Sharpley (2004) trata-se fundamentalmente de reconhecer que são muitos os formatos de empreendimentos e atividades no espaço rural. Novamente, as fragilidades conceituais se apresentam.

\subsection{Perfil da demanda}

Como apontado anteriormente, há uma forte relação entre a localização dos empreendimentos e os centros emissores de sua demanda, fato ratificado pela informação sobre a origem dos visitantes dos empreendimentos que participaram do levantamento. Conforme se observa na Figura 23, a cidade de São Paulo (73,2\%) e os municípios da Grande São Paulo (32,3\%) são os locais de origem da maior parte dos turistas que visitam estas propriedades. Depois destacam-se grandes centros urbanos do interior do Estado, como Campinas (39,9\%), São José dos Campos (20,2\%), Ribeirão Preto (19,2\%) e Sorocaba 
(15,7\%). A indicação de turistas advindos de outros estados, exceto Minas Gerais (6,6\%), provavelmente pela proximidade das regiões onde se encontram os empreendimentos, é muito pequena, assim como a presença de turismo internacional $(4,0 \%)$.

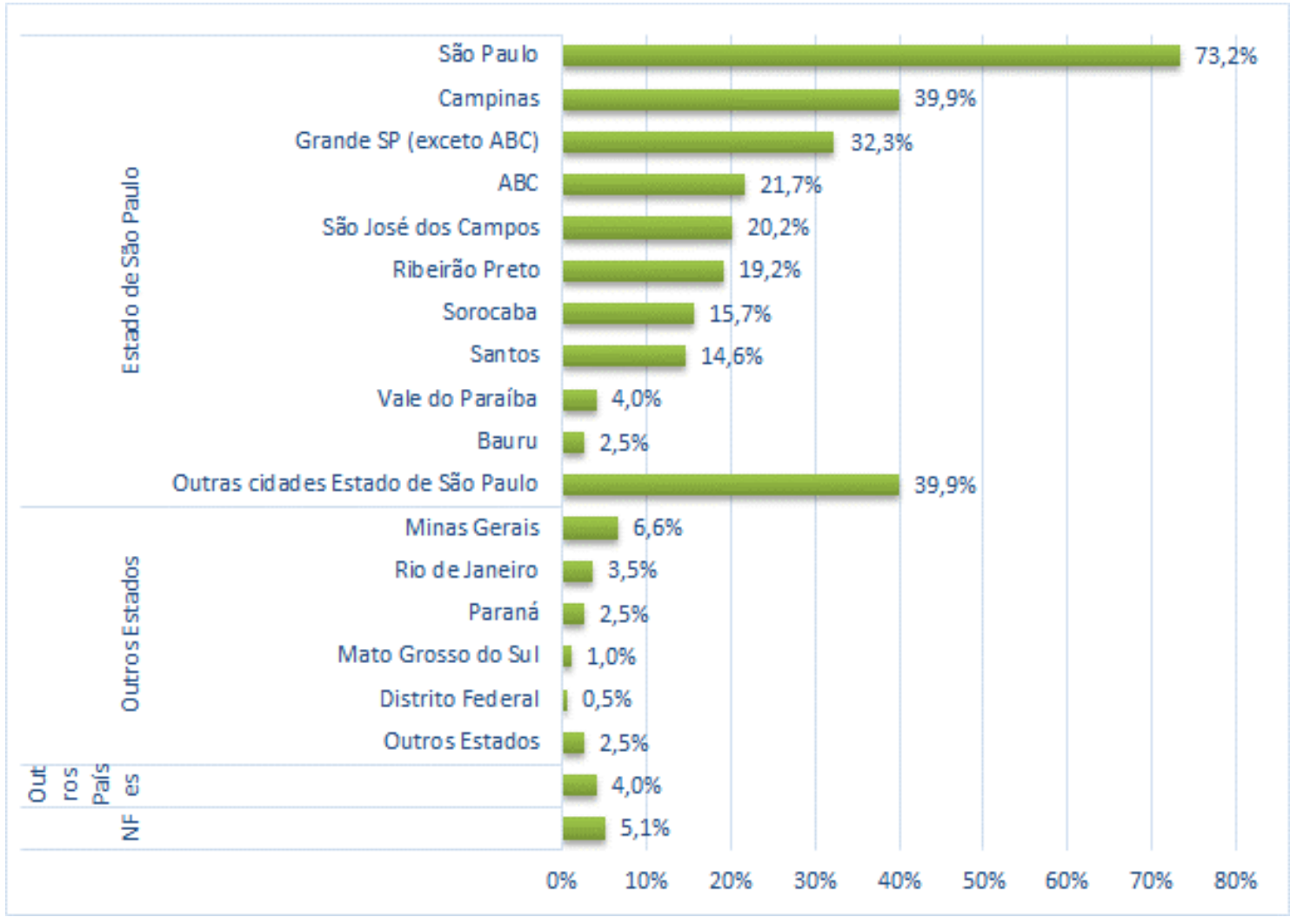

Figura 23 - Orgiem dos visitantes do Empreendimento de Turismo rural no Estado de São Paulo.

Nota. Fonte: Elaboração da autora com base ABRATURR - 2014

Trata-se de negócios familiares, de pequeno porte, com poucos empregados, próximos a grandes centros urbanos, com muitas restrições operacionais, de gestão e de infraestrutura. Estas limitações estão refletidas também nas estratégias comerciais e principalmente na divulgação. Como pode ser observado na Figura 24, predomina o uso da comunicação bocaa-boca $(73,7 \%)$ e o material impresso como folhetos (53\%), cartão de visita (40,4\%), além de revistas $(19,7 \%)$ e jornal $(19,2 \%)$ ainda fazem parte das estratégias de comunicação destes empreendimentos. 


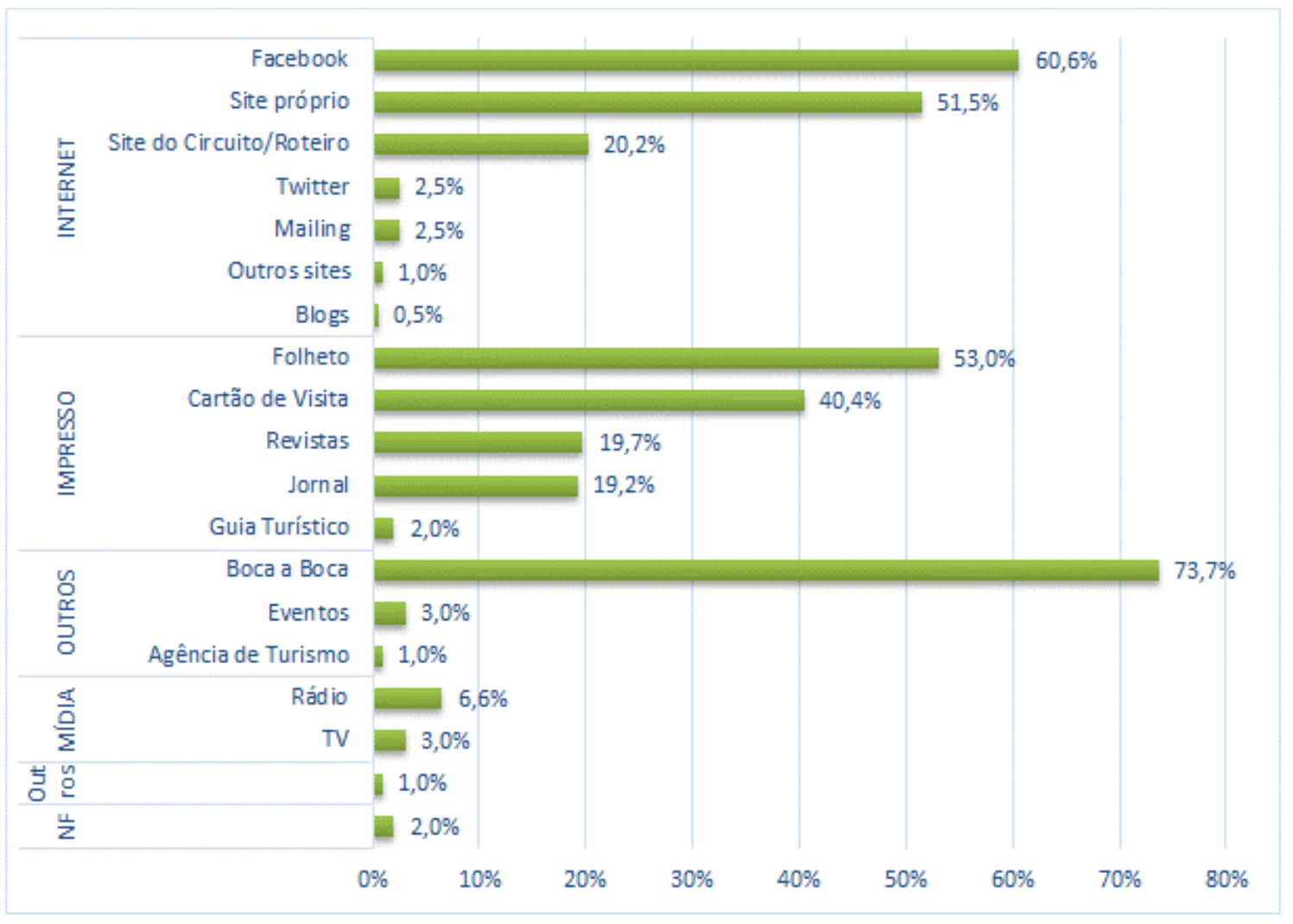

\section{Figura 24 - Empreendimentos de Turismo rural do Estado de São Paulo segundo as estratégias de divulgação}

Nota. Fonte: Elaboração da autora com base ABRATURR - 2014

$\mathrm{Na}$ internet há um uso expressivo da rede social Facebook (60,6\%), além de site próprio (51,5\%), o que não significa que produza resultados efetivos. Uma única ação de comercialização colaborativa foi citada, a presença no site de Circuito ou Roteiro Turístico $(20,2 \%)$

O pouco conhecimento sobre o perfil e o comportamento dos visitantes certamente remete à formatação de produtos e serviços e, principalmente, nas estratégias de divulgação e comercialização de modo geral muito incipientes e amadoras. Apesar da validade da iniciativa da ABRATURR na realização de um levantamento atualizado dos empreendimentos de turismo rural no estado, e do retorno qualificado que conseguiu obter, muitos questionamentos ainda permanecem sem resposta. 
Por exemplo, a questão da demanda deveria ser uma prioridade nos estudos e levantamentos do segmento, pois a partir destes resultados os diferentes empreendedores poderiam aprimorar os seus produtos e serviços articulando os princípios do turismo do rural com os interesses dos diferentes públicos. A questão da segmentação nem foi mencionada diretamente, mas se observa uma sinalização tênue de que faz parte da proposta de alguns empreendimentos. Não se trata apenas de identificar nichos de mercado por interesse, por faixa etária, mas também considerar que a oferta de roteiros e atividades criativas apoiadas no patrimônio e no meio ambiente pode garantir maior fluxo de visitantes, com atitudes coerentes com a que se deseja para o ambiente rural.

Nesse sentido Kastenholz e Lima (2011, p.71) salientam que “...a questão de como fazer, como planejar e gerenciar com sucesso produto de turismo rural é, além de satisfazer os turistas, contribui para o desenvolvimento sustentável de destinos turísticos, é um tema crucial para as áreas rurais quando escolhem o turismo como um instrumento de desenvolvimento."

Entende-se que a preocupação em identificar e compreender o comportamento do consumidor de turismo rural, pode trazer informações valiosas para o aprimoramento dos empreendimentos e do próprio segmento. 


\section{Considerações Finais}


A ciência está longe de ser um instrumento perfeito de conbecimento. É apenas o melhor que temos. Nesse aspecto, com em muitos outros, ela se parece com a democracia. A ciência por si mesma, não pode defender linhas de ação bumana, mas certamente pode iluminar as possiveis consequências de linhas alternativas de ação. (Sagan, 1996, p.41)

O turismo rural se origina como uma estratégia para estimular o desenvolvimento em áreas rurais em declínio, e assim em alguns países europeus recebeu, por um longo período, atenção especial das políticas públicas e um aporte significativo de recursos e apoio técnico para sua implementação. Ainda hoje é objeto de vários estudos que analisam os resultados destes investimentos e que também indicaram a necessidade de compreender esta realidade a partir de uma abordagem interdisciplinar, porque não se trata exclusivamente de compreender a dinâmica do rural, mas sua inserção numa sociedade em profunda transformação. Entre os reflexos desta evolução está a presença cada vez mais expressiva, no âmbito das pequenas e médias propriedades agrícolas, das atividades denominadas nãoagrícolas, nas quais estão incluídas aquelas relacionadas ao lazer e ao turismo.

Recentemente tem-se verificado alterações no perfil da população rural, resultado de migração de uma parte da população urbana para as áreas rurais. Não se trata somente de um movimento de retorno daqueles que de alguma forma viveram ou tem profundas relações com o campo, mas de moradores urbanos na busca de um estilo de vida saudável e equilibrado. Um novo cenário emerge assim, sendo objeto de estudo de vários pesquisadores que denominam este processo, em andamento, como novas ruralidades.

Este cenário que está se configurando tem profundos reflexos no segmento de turismo rural, que, já consolidado em diversos lugares, busca seu aprimoramento e uma inserção mais qualificada e profissional no turismo. Ao mesmo tempo observa-se a ampliação do interesse dos turistas pelo consumo deste tipo de experiência. A conjugação de tais fatores provoca 
uma grande apreensão, porque exige um posicionamento diante de um dilema: Como preservar a ruralidade e ao mesmo tempo tornar-se um produto turístico competitivo?

Certamente vai exigir um grande esforço de superação, pois para atuar neste cenário não será mais possível agir de modo individual e amador. O que até então era tratado na perspectiva de empreendimentos rurais deverá considerar uma ampliação de entendimento em direção à configuração de destinos rurais como apontado por diversos pesquisadores do exterior.

Esta transformação também está em processo no Brasil, ainda que de modo incipiente. A trajetória do turismo rural no país tem cerca de trinta anos, sendo reconhecido como um segmento relevante pelo poder público federal, tanto do turismo quanto do desenvolvimento agrário. Tem ao longo do tempo contado com a atenção e o apoio de entidades como o SEBRAE e o SENAR que buscam aprimorar a atuação dos empreendedores na área.

A isto se agrega o envolvimento dos pesquisadores de várias áreas do conhecimento nas discussões sobre a temática. A presença de atividades de lazer e turismo no campo tem emergido nos estudos dedicados exclusivamente à questão agropecuária, e até nos censos agropecuários de abrangência nacional e estadual, despertando a atenção dos profissionais e pesquisadores dedicados aos estudos sobre o universo agrícola. Mas apesar de todos os esforços, ainda não estão disponíveis dados consistentes sobre sua expressão ou mesmo sua dinâmica, informações que seriam essenciais para a elaboração de políticas púbicas adequadas e para subsidiar a ação dos empreendedores.

Esta situação também pode ser observada no cenário paulista e tem sido timidamente averiguada pelos investigadores, especialmente aqueles ligados à área de turismo e geografia da Universidade de São Paulo. A questão do desenvolvimento parece ser o principal motivador para os estudos realizados, os quais identificaram empreendimentos de turismo rural distribuídos por quase todo o território do Estado. 
Verificou-se que a maior parte dos estudos sobre o turismo rural paulista foram realizados no início da implementação do segmento em São Paulo, entre 2001 a 2005, e perderam a expressão depois disso. Enquanto que os empreendedores e profissionais dedicados ao turismo rural têm se mobilizado e atuado de forma permanente, nota-se a expansão e o aprimoramento dos negócios, além da inserção em diferentes espaços de representação junto ao poder público; e também contam com o interesse permanente de entidades como o SEBRAE e o SENAR estaduais.

Compreende-se o distanciamento dos pesquisadores dedicados exclusivamente à agricultura, em uma extensa pauta de temas e outras prioridades. Mas a temática do turismo rural permeia outras áreas de conhecimento como patrimônio, antropologia, geografia, comunicação e administração, as quais tem presença muito pontual na discussão sobre a temática. No entanto, os poucos estudos que foram realizados recentemente ressaltam que outras áreas de conhecimento podem contribuir de forma notável para o avanço dos debates e da compreensão desta realidade.

Aos poucos estudos sobre a realidade paulista associa-se a ausência de dados sobre a presença do turismo e do lazer como atividade nas unidades produtivas rurais do Estado, apesar dos esforços realizados em meados da década de 2000, como o levantamento do Guia de Turismo Rural e do Projeto LUPA/CATI. Mesmo assim, verificou-se uma intensa e relevante atuação de entidades como SEBRAE/SP e o SENAR/SP na oferta de apoio técnico e capacitação, estimulando as iniciativas dos empreendedores do turismo rural paulista.

Neste cenário o poder público teve uma presença acanhada e pouco articulada tanto na agricultura como no turismo. No entanto, isso tem se modificado em função da capacidade de geração de negócios que a atividade demonstra nos pequenos municípios e também em 
função da permanente e reconhecida atuação da ABRATURR representando o interesse dos empreendedores de turismo rural do Estado.

Com uma trajetória marcada pela superação, os empreendedores de rural tem conseguido manter os seus negócios, sendo que um número expressivo atua no segmento há mais de dez anos, e vários outros estão em processo de consolidação e mesmo iniciando sua jornada. Então não se trata mais de oferecer condições para implementação de novos negócios, mas sim de suporte para o fortalecimento e aprimoramento da atuação destes empreendedores diante dos desafios contemporâneos.

Entre estes, destacam-se a formatação de produtos e serviços de qualidade, que promovam não apenas o simples consumo da paisagem, contrapondo os ritmos de urbano x rural, mas valorizando diferentes práticas agrícolas e o patrimônio cultural do universo rural paulista. Mas para tanto será necessário um trabalho coletivo dos diferentes setores que atuam no segmento. E porque não recuperar aquilo que o mundo rural traz de mais valioso revelado em suas mais antigas tradições, como os cantos de trabalho conhecidos como "brão"29, cantados nos dias de mutirão quando um agricultor contava com a ajuda dos vizinhos para atividades de grande monta, como colheita ou a limpa do roçado.

Assim, esta pesquisa espera ter contribuído na composição de um panorama a partir de fragmentos de informação, obtidos na leitura das dissertações e teses sobre o turismo rural paulista articulados com os dados coletados juntos aos empreendedores que estão em atividade. Seguramente não se configura em um quadro detalhado com as nuances deste complexo cenário, mas pistas que permitem identificar os diversos elementos que o compõem e assim oferecer subsídios para uma próxima investigação.

\footnotetext{
29 "O brão é um canto sem instrumentos que se entoa durante o trabalho do mutirão. Sempre cantado em dupla, exige que seus artistas trabalhem juntos para que, a todo momento, se reúnam e, descansando do trabalho com a enxada, realizem um trabalho com a voz". (Brandão, 1983, p. 83)
} 
Referências Bibliográficas 


\section{TESES E DISSERTAÇÕES SOBRE O TURISMO PAULISTA}

Bernardi, A. (2009). Estratégias de desenvolvimento local e regional: um estudo sobre o Circuito das Frutas e sua articulação com a região Metropolitana de Campinas. Dissertação de Mestrado, Universidade Estadual de Campinas, Campinas.

Blos, W. S. (2007). Vidas em circulação: experiência turística e momentos de ruptura entre turistas paulistanos em São José do Barreiro. Tese de Doutorado, Faculdade de Filosofia, Letras e Ciências Humanas, Universidade de São Paulo, São Paulo.

Bovo, C. E. O. (2004). Turismo rural realmente rural - radiografia crítica no Estado de São Paulo. Dissertação de Mestrado, Universidade Federal de Santa Maria, Santa Maria.

Carvalho, A. N. (2012). Análise da relação simbólica da hospitalidade: desdobramentos e apropriações em fazendas históricas inseridas em espaços rurais. Tese de Doutorado. Universidade Estadual Paulista, Rio Claro.

Costa, C. R. da (2001). Elementos para o planejamento turístico em Monteiro Lobato. Dissertação de Mestrado, Universidade do Vale do Paraíba, São José dos Campos.

Cunha, K. P. L. da (2004). Patrimônio e lugar: o turista no espaço rural de Mococa e seu interesse no atrativo histórico cultural. Dissertação de Mestrado. Escola de Comunicações e Artes, Universidade de São Paulo, São Paulo.

Dale, P. J. (2001). Novas dimensões da ruralidade: turismo e desenvolvimento territorial. Dissertação de Mestrado, Programa de Pós Graduação em Ciência Ambiental, Universidade de São Paulo, São Paulo.

Dias, C. M. M. (1996). Ribeirão Preto: Le pays du café: proposta de utilização turística em fazendas históricas. Tese de Doutorado, Escola de Comunicações e Artes, Universidade de São Paulo, São Paulo.

Esteves, M. C. (2004). A sustentabilidade dos empreendimentos rurais: um estudo a partir da implantação do turismo rural no Estado de São Paulo. Dissertação de Mestrado, Universidade Federal de São Carlos, São Carlos.

Faustino, R. F. (2006). O Turismo em espaço rural como modo de valorização do patrimônio cultural (Estudo de caso na média depressão periférica paulista: As fazendas Capoava e Ibicaba). Tese de Doutorado, Faculdade de Filosofia, Letras e Ciências Humanas, Universidade de São Paulo, São Paulo.

Felice, A. de (2002). Turismo rural para a terceira idade. Dissertação de Mestrado, Escola de Comunicações e Artes, Universidade de São Paulo, São Paulo. 
Geraldo, J. C. (2012). Contribuição para caracteriz̧ação das atividades de turismo em espaço rural em propriedades de médio e grande porte nas Cuestas do Estado de São Paulo. Tese de Doutorado, Universidade Estadual Paulista, Rio Claro.

Gonçalves, K. D. (2004). A municipalização na formação de produtos turisticos regionais: pólo turístico do Circuito das frutas. Dissertação de Mestrado. Escola de Comunicações e Artes, Universidade de São Paulo, São Paulo.

Ishiy, M. (2002). Experiências brasileiras em agroturismo: o exemplo da Fazenda Floresta (LupércioSP). Dissertação de Mestrado. Escola de Comunicações e Artes, Universidade de São Paulo, São Paulo.

Morais, L. G. L. (2010). Turismo, cultura e velhice bem-sucedida : contribuições para a elaboração de atividades turístico-culturais para idosos no contexto de fazendas históricas paulista. Dissertação de Mestrado, Universidade Estadual de Campinas, Campinas.

Moreira, E. V. (2012). A ruralidade e a multifuncionalidade nos espaços rurais de Piedade e Pilar do Sul-SP. Tese de Doutorado, Universidade Estadual Paulista, Presidente Prudente.

Oliveira, C. G. de S. (2001). Turismo rural: procedimentos para implantação dessa atividade em propriedades rurais do Estado de São Paulo. Dissertação de Mestrado, Escola de Comunicações e Artes, Universidade de São Paulo, São Paulo.

Pinho, A. M. (2014). Turismo rural, sustentabilidade e o serviço público de extensão rural no Estado de São Paulo. Dissertação de Mestrado, Universidade Federal de São Carlos, São Carlos.

Pinto, W. C. , Jr. (2005). Informação e tecnologia para a implantação do agroturismo em Echaporã - SP. Dissertação de Mestrado. Universidade Estadual Paulitas, Marília.

Ribeiro, M. L. (2002). Novas formas de ocupação do meio rural e natural do município de CaçapavaSP: o caso do entorno no núcleo de Guaramirim (Piedade). Dissertação de Mestrado, Planejamento Urbano e Regional, Universidade do Vale do Paraíba, São José dos Campos.

Severino, F. C. G. (2006). Turismo e conservação no cenário rural do entorno de uma unidade de conservação no município de Luir. Antonio - SP. Dissertação de Mestrado, Universidade Federal de São Carlos, São Carlos.

Soares, M. D. de O. (2007). As contradições do turismo no espaço rural: vida, trabalho, renda e exclusão. Tese de Doutorado. Universidade Estadual de Campinas, Campinas.

Viegas, J. F. (2005). Turismo sustentável em áreas de manancial: análise de vocação turística da regiã ode Parelheiros, RMSP. Dissertação de Mestrado, Universidade São Marcos, São Paulo.

Vieira, E. M. (2005). Politicas Públicas e legislação para o turismo rural. Dissertação de Mestrado, Universidade Federal de Santa Maria, Santa Maria. 


\section{OUTRAS FONTES CONSULTADAS}

Amadeus (2015). Future traveller tribes- 2020. (Relatório Técnico). Henley Centre Headlightvision. Recuperado em 15 de agosto de 2015, de: http://www.amadeus.com/documents/future-traveller-tribes-2030/travel-report-futuretraveller-tribes-2020.pdf.

Associação das Fazendas Históricas Paulistas. (2016). Recuperado em 10 de julho de 2016, de: http://www.fazendaspaulistas.com.br/index.php?topico=nav/apresenta.

Barbieri, C. \& Mahoney, E. (2009). Why the diversification and attractive farm adjusment strategy? Insights from Texas farmers and ranchers. Journal of Rural Studies, 25, 58-66.

Bardin, Laurence. (1995). Análise de conteúdo. Lisboa: Edições 70.

Bastos, Sênia Regina. (2005). Produção acadêmica do Programa de Mestrado em Hospitalidade. Revista Hospitalidade, 2(1), 89- 95.

Brandão, C.R. (1983). Os caipiras de São Paulo. Coleção Tudo é História. São Paulo: Brasiliense.

Canoves, G. et al. (2004). Rural tourism in Spain: an analysis of recente evolution. Geoforum, 35, 755-769.

Costa, L. S. F. et al. (2013). Patrimonio Rural Paulista: espaço privilegiado para o ensino, a pesquisa e o turismo. In R. C. C. Thomaz et al (Org.), Turismo, políticas e dinâmicas no espaço rural (121-134). Campo Grande: UFMS.

Cristovão, A. et. al. (2012). Turismo rural em tempos de novas ruralidades. In Actas do VIII CITURDES. Chaves. Portugal. Recuperado em 02 de setembro de 2016, de: http://www.pasosonline.org/Publicados/pasosoedita/pasosrep7.pdf

Dencker, A. M. de. F. (2007). Pesquisa em turismo: planejamento, métodos e técnicas. 9a ed. São Paulo. Futura.

Elesbão, I. (2014). O turismo no contexto das transformações do espaço rural brasileiro. In A. Cristovão, et al (Org.), Turismo rural em tempos de novas ruralidades (pp.241-266). Porto Alegre: UFRGS.

EMBRATUR.(1994). Turismo Rural: Manual Operacional. Brasília.

Esteves, M.C. (2001). O SEBRAE-SP e o turismo rural no Estado de São Paulo. In Anais do $3^{\circ}$ Congresso Brasileiro de Turismo Rural (pp. 99-104). Piracicaba: FEALQ.

Eusébio, C \& Figueiredo, E. (2014). Turismo e desenvolvimento sustentável em destinos rurais. In Reinventar o turismo rural em Portugal - cocriação de experiências turísticas sustentáveis, (pp. 51-58).Aveiro: UA Editora.

Evans, N. J. \& Ilbery, B.W. (1989). A conceptual framework for investigating farm-based accommodation na tourism in Britain. Journal of Rural Studies, 5 (3), 257-266.

FAESP \& SENAR (2010). SENAR atinge a marca histórica de mais de dois milhões de participantes em seus cursos e programas de formação profissional rural e promoção social. Informativo FAESP/SENAR/SP, VI(1), 14-20. 
FAESP \& SENAR (2011). Formação profissional: turismo tem novas ações para 2012. Informativo FAESP/SENAR/SP, VII (6), 48-49.

Fedrizzi, Valéria Luiza Ferreira. (2008). O conhecimento gerado no programa de mestrado em hospitalidade da Universidade Anhembi Morumbi - UAM. Dissertação de Mestrado, Universidade Anhembi Morumbi, São Paulo.

Ferreira, N. S. de A. (2002). As pesquisas denominadas "estado da arte". Educação Eamp; Sociedade, XXIII (79), 257-272.

Ferri, Cássia (Coord.). (2011). Produção acadêmico-científica: a pesquisa e o ensaio. Itajaí: Univali.

Froehlich, J.M. (2000). Turismo rural e agricultura familiar: explorando (criticamente) o cruzamento de abordagens e estratégias para o desenvolvimento. In J. Anécio \& M. Reidl, Turismo rural: ecologia, lazer e desenvolvimento (pp.181-197). Bauru: EDUSC.

Getz, D. \& Carlsen, J. (2000). Characteristics and goals of Family and owner-operated business in the rural tourism and hospitality sectors. Tourism Management, 21, 547-560.

Hespanhol, A.N. (2013). O turismo nos espaços rurais do oeste paulista: possibilidades e limites. In R.C.C. Thomas, et al. (Org.). Turismo, políticas e dinâmicas no espaço rural (pp.227246). Campo Grande: Editora UFMS.

Heyerdahl, T. (1987). A Expedição Kontiki. Ga ed. Rio de Janeiro: José Olympio Editora.

Hjalager, A.M. (1996). Agricultural diversification into tourism: Evidence of a European Community development programme. Tourism Management, 17(2), 103-111.

IBGE. (2015). Projeto Regiões Rurais -2015 (Relatório Técnico), Rio de Janeiro, RJ, . Ministério do Planejamento, Orçamento e Gestão. Recuperado em 19 janeiro, 2016, de: http:/ / biblioteca.ibge.gov.br/index.php/biblioteca-catalogo?view $=$ detalhes\&id $=294413$

IBGE. (2011). Atlas do espaşo rural brasileiro. Rio de Janeiro. Recuperado em 19 janeiro, 2016, de: http:/ / biblioteca.ibge.gov.br/biblioteca-catalogo?view=detalhes\&id=263372.

IICA (2009). Diagnóstico del turismo rural en el Brasil. un concepto en contrucción. 2009. Recuperado de: http://www.iicabr.iica.org.br/.

Instituto Geográfico Nacional. (2008). Turismo en espacios rurales y naturales. Madrid, Espanha.

Kastenholz, E. \& Lima, J. (2011). The integral rural tourism experience from the tourist's point of view - a qualitative analysis of its natue and meanning. Tourism \& Management Studies, (7), 62-74.

Kastenholz, E. (2011). Marketing de empreendimentos e destinos turísticos rurais - uma abordagem integrada. In M. Souza, \& I. Elesbão (Org.), Turismo rural: iniciativas e inovações (pp.215-242). Porto Alegre: UFRGS.

Kastenholz, E. et al. (Org.). (2014). Reinventar o turismo rural em Portugal - cocriação de experiências turisticas sustentáveis. Aveiro: UA Editora, 2014. Recuperado em 10 de dezembro de 2015, de: http://www.pasosonline.org/Publicados/pasosoedita/PSrep12.pdf

Korstanje, M. E. (2014). Critica al concepto de internacionalización de Douglas Pearce. Rosa dos Ventos - Turismo e Hospitalidade, 6(1), 117-120. 
Lane, B. (2014). Turismo rural de segunda geração: prioridades e questões de pesquisa. In. A. Cristovão, et al (Org.), Turismo rural em tempos de novas ruralidades (pp.15-48). Porto Alegre: UFRGS

Luques, A.C. (2014). O equestre no turismo rural do Estado de São Paulo - uma análise exploratória. Trabalho de Conclusão de Curso, Escola de Artes, Ciências e Humanidades, Universidade de São Paulo, São Paulo.

Maldonado, C. (2009). O turismo rural comunitário na América Latina: genesis, características e políticas. In R. Bartholo, et al (Org.), Turismo de Base Comunitária: diversidade de olhares e experiências brasileiras. Rio de Janeiro: Letra e Imagem.

Mazuel, L. (2000). Patrimônio cultural e turismo rural: o exemplo francês. In J. Anécio \& M. Reidl. Turismo rural: ecologia, lazer e desenvolvimento (pp. 95-114). Bauru: EDUSC.

MINTUR (2004). Diretrizes para o desenvolvimento do turismo rural. Ministério do Turismo, Brasília.

MINTUR (2008). Orientações básicas para o turismo rural. Ministério do Turismo, Brasília.

Oliveira, C.G.de S. (2004). Gestão do turismo rural. In D. Ruschmann \& K.T. Solha, Turismo: uma visão empresarial. (pp. 46-66). Barueri: Manole.

OMT. (2003). El turismo rural en las Américas y su contribución a la creación de empleo y la conservación del patrimônio.

Orsolya, S. E. (2015). The trends of rural tourism research in the past fifteen years. SITCOM - Singidunum International Tourism Conference, 222-228. Recuperado em 10 de julho de 2016, de: http://portal.sitcon.singidunum.ac.rs/paper/41.

Pearce, D. (2012). Comprometiendose com el mundo: América Latina y la internacionalización de la investigación en turismo. Estudios y Perspectivas en Turismo, 22, 908925.

Pearce, D. (2014). The internationalization of tourism research. Journal of Travel Research, 58(3), 267-280.

Pires, M.J. (2001a). Lazer e turismo cultural. Barueri: Manole.

Pires, M.J. (2001b). Raizes do turismo no Brasil. Barueri: Manole.

Portugues, A.P. (2005). Turismo rural. In. L. G. G. Trigo, et al (Org.), Análises regionais e globais do turismo (pp.577-586). São Paulo: Editora Roca.

Pulido Fernandez, J. (2008b). El turismo rural. Madri: Sintesis.

Pulido Fernandez, J. (2014). Innovacion y redes como respuesta a los cambios em la demanda de turismo rural. In Anais do $9^{\circ}$ CITURDES. ECA/USP. São Paulo. Recuperado em 10 de novembro de 2015, de: http://143.107.95.102/prof/kasolha/citurdes/anais/.

Pulido Fernandez, J. (Coord.). (2008a). Mercados de origen y destinos competidores del turismo rural espanhol. In J. Pulido Fernandez, El turismo rural: estrutura econômica y configuracion territorial em España. Madri: Sintesis

Queiroz, O.T. M. M. (2012). O aproveitamento turístico dos patrimônios cultural e natural e seus impactos socioeconômicos e ambientes em espaço rural: o caso dos Solares portugueses e as fazendas históricas paulistas. (Relatório de Pesquisa). Portugual, Universidade de Nova Lisboa. 
Rejowski, M. (1996). Turismo e pesquisa cientifica: pensamento internacional x situação brasileira. Campinas: Papirus.

Rejowski, Mirian. (1993). Pesquisa acadêmica em turismo no Brasil (1975-1992): configuraçãoe sistematização documental. Tese de Doutorado, Universidade de São Paulo, São Paulo.

Rodrigues, A.B. (2001). Turismo rural no Brasil: ensaio de uma tipologia. In. A.B. Rodrigues (Org.), Turismo rural: práticas e perspectivas. São Paulo: Contexto.

Roque, A. (2004). Turismo Rural - Região Sudeste. São Paulo. Editora Turismo de Campo.

Roque, A. (2006). Guia do Turismo de Campo. Turismo Rural do Estado de São Paulo.São Paulo. Editora Turismo de Campo.

Roque, A. (2012). Panorama Empresarial do Turismo Rural. IDESTUR/SEBRAE. São Paulo. Recuperado em 23 de novembro de 2015, de: http://www.idestur.org.br/pdf/panorama.pdf.

Roque, A. (2014). Turismo rural - reconhecimento e legalização. Como resultado, sustentabilidade e mercado. Confederação Nacional do Comércio, Bens, Serviços e Turismo, Edição Especial. Turismo Rural, 21, 49-54.

Roque, A. (2016). Entrevista realizada em São Paulo, no dia 29 de junho de 2016.

Roscoche, L.F.; Carvalho, R.C. de (2006). Os conceitos de turismo no meio rural e as diferentes realidades regionais do Brasil: estudo comparativo preliminar entre Pernambuco e Paraná. In A.P Portugues, et al (Org.). Turismo no espaço rural: enfoques e perspectivas (pp. 269279). São Paulo: Roca.

Sagan, C. (1996). O mundo assombrado pelos demônios. São Paulo: Companhia das Letras.

Santos, A. S. (2008). O turismo rural sob a perspectiva do "novo rural": uma análise das políticas públicas para o setor nos estados brasileiros. Dissertação de Mestrado, Universidade do Vale do Itajaí, Balneário Camboriu.

São Paulo (2008). Projeto Lupa. Secretaria de Agricultura e Abastecimento. Recuperado em 20 de fevereiro de 2016, de: http://www.cati.sp.gov.br/projetolupa/sobreolupa.php.

Saxena, G. \& Ilbery, B. (2010). Developing integrated rural tourism: actor practices ein the English/welsh border. Journal of Rural Studies, 26, 260-271.

SEBRAE. (2013). Retrato do turismo rural no Brasil com foco nos pequenos negócios. Brasília. Recuperado em 10 de novembro de 2015, de: http://www.bibliotecas.sebrae.com.br/chronus/ARQUIVOS_CHRONUS/bds/bds.nsf/9 e845a6d413535b25fd040f6c5ea079e/\$File/5142.pdf.

Sharpley, R. (2004). Tourism and the countryside. In A, Lew, M .C. Hall, \& M. Williams, $A$ companion to tourism (pp. 347-386). UK: Blackwell Publishing.

Silva, A.F. da (2014). Retrato do Turismo Rural no Brasil, com foco nos Pequenos Negócios - Perfil Empresarial. In Anais do $9^{\circ}$ CITURDES. ECA/USP. São Paulo. Recuperado em 04 de maio de 2015, de: http://143.107.95.102/prof/kasolha/citurdes/anais/pdf/eixo5/GT5_4.pdf. 
Silva, J. G. da \& Grossi, M. E. del (2000). O novo rural brasileiro. Ocupações rurais não Agrícolas. Oficina de Atualização Temática. Projeto Rurbano. Recuperado em 09 de janeiro de 2015, de: http://www.iapar.br/arquivos/File/zip_pdf/novo_rural_br.pdf.

Silva, J.G. da et al. (1996). O rural paulista: muito além do agrícola e do agrário. São Paulo em Perspectiva, 10 (2). Recuperado em 01 de janeiro de 2016, de: http://produtos.seade.gov.br/produtos/spp/v10n02/v10n02_09.pdf .

Skift (2015). Megatrends defining travel in 2015. Recuperado em 03 de agosto de 2015, de: https://skift.com/2015/01/13/new-skift-magazine-megatrends-defining-travel-in-2015/.

Solha, K.T. \& Rejowski, M. (2013). Produção científica sobre turismo rural no Brasil: percepções do poder público, da iniciativa privada e dos pesquisadores. Revista Turismo \& Desenvolvimento, 20, 111-120.

Solha, K.T. (2012). O turismo rural como objeto de estudo nas pesquisas acadêmicas: a realidade brasileira. In Anais do VII Citurdes, Tras os Montes. Portugal. Recuperado em 18 de março de 2016, de: http://www.pasosonline.org/Publicados/pasosoedita/pasosrep7.pdf

Théry, H \& Mello, N. A. (2005). Atlas do Brasil: disparidades e dinâmicas do território. São Paulo: EDUSP.

Tulik, O. (1997). Do conceito às estratégias para o desenvolvimento do turismo rural. In A.B. Rodrigues (Org.), Turismo e desenvolvimento local (136-143). São Paulo: Hucitec.

Tulik, O. (2001). Turismo e meios de hospedagem: casas de temporada. São Paulo: Roca.

Tulik, O. (2003). Turismo Rural. Coleção ABC do Turismo. São Paulo: Aleph.

Tulik, O. (2010). Turismo e desenvolvimento no espaço rural: abordagens conceituais e tipologias. In E. de O. Santos \& M. Souza (Org.), Teoria e prática do turismo no espaço rural (pp.2-22) Baureri: Manole.

Varisco, C. A. (2016). Turismo rural: propuesta metodológica para um enfoque sistêmico. Revista de Turismo y Patrimonio Cultural, 14(1), 153-167.

Veiga, J.E. da (2001). O Brasil rural ainda não encontrou seu eixo de desenvolvimento. Estudos Avançados, 15 (443), 101-119.

Vilela, I. (2013). Uma proposta para o uso da música no segmento do turismo rural. Estudos Avançados, 27(79), 207-223.

Wanderley, M. de N. B. (2000). A emergência de uma nova ruralidade nas sociedades modernas avançadas - o "rural" como espaço singular e ator coletivo. Estudos Sociedade e Agricultura, 15, 87-145.

Wanderley, M. de N.B. (2001). A ruralidade no Brasil moderno. Por um pacto social pelo desenvolvimento rural. In N. Giarraca (Ed.), Uma nueva ruralidad en America Latina? (pp. 31 44). Buenos Aires: CLACSOP. 
Anexos 


\section{ANEXO A \\ ABRATURR - SP \\ TURISMO RURAL PAULISTA - DADOS E FATOS}

\section{INVENTÁRIO DE EMPREENDIMENTOS E ROTEIROS DE TURISMO RURAL DO ESTADO DE SÃO PAULO.}

Com a proximidade da aprovação no Congresso Nacional de Lei que regulamenta a atividade de Turismo Rural no país, necessitados saber qual é o universo de empreendimentos e roteiros existentes no segmento de Turismo Rural no Estado de São Paulo.

Por meio deste questionário elaborado pela ABRATURR São Paulo e IDESTUR - Instituto de Desenvolvimento do Turismo Rural e com apoio da Aprecesp, Sebrae e outros órgãos estaremos realizando, até o final do mês de agosto de 2014, em todo o estado, um levantamento e contamos com apoio dos órgãos públicos, entidades de classe, faculdades e principalmente os empreendimentos de turismo rural.

O Marco Conceitual do Ministério do Turismo para Turismo Rural é - "Conjunto das atividades turísticas desenvolvidas no meio rural, comprometidas com a produção agropecuária, agregando valor a produtos e serviços, resgatando e promovendo o patrimônio cultural e natural da comunidade". Favor preencher o questionário abaixo caso seu empreendimento esteja inserido nesse contexto. Desde já agradecemos. Obs- Data limite para envio do formulário preenchido - 30 de setembro de 2014 - $4^{a}$ fase do levantamento (período de levantamento de propriedades potenciais que ainda não enviaram o questionário).

1) Qual região adminstrativa do Estado de São Paulo se encontra o empreendimento ou roteiro de turismo rural?

O estado de São Paulo está dividido em 16 regiões administrativas.

$\begin{array}{ll}\circ & \text { Central (Araraquara e São Carlos } \\ \circ & \text { Araçatuba } \\ \circ & \text { Barretos } \\ \circ & \text { Bauru } \\ \circ & \text { Campinas } \\ \circ & \text { Franca } \\ \circ & \text { Itapeva } \\ \circ & \text { Marília } \\ \circ & \text { Presidente Prudente } \\ \circ & \text { Registro } \\ \circ & \text { Ribeirão Preto } \\ \circ & \text { Santos } \\ \circ & \text { São José do Rio Preto } \\ \circ & \text { São José dos Campos } \\ \circ & \text { Sorocaba } \\ \circ & \text { Metropolitana de São Paulo }\end{array}$

2) O empreendimento integra algum Roteiro, Circuito, Corredor ou Rota de Turismo?
- Circuito das Frutas (Região Jundiaí)
- Roteiro do Vinho (São Roque)
- Caminho da Roça (Socorro)
- Pólo Cuesta (Região Botucatu)
- Mantiqueira (Região Campos do Jordão)
- Caminhos do Tietê (Região de Barra Bonita)
- Aventura e Lazer (Região de Capão Bonito)
- Café com Leite (região de Mococa)
- Fazendas Históricas Paulistas
- Chapada Guarani (Região de Brotas)
- Circuito das Águas Paulista
- Circuito dos Bandeirantes (Região de Itu) 
○ Não integra nenhum roteiro, circuito

O Outro:

3) Qual cidade do Estado de São Paulo está localizado o empreendimento?

4) Nome de Fantasia de seu empreendimento

5) Principal atividade desenvolvida no empreendimento de Turismo Rural? Favor escolher nessa pergunta apenas uma atividade
- Restaurante Rural
- Pesqueiro
- Alambique
- Vinícola
- Day Use
- Camping
- Hospedagem
- Hípica
- Colhe e pague
- Trilha ecológica
- Artesanato
o Outro:

6) Outra(s) atividades desenvolvidas no empreendimento de Turismo Rural Múltipla escolha
○ Restaurante Rural
- Pesqueiro
- Alambique
- Vinícola
- Day Use
- Camping
- Hospedagem
○ Hípica
- Colhe e pague
- Trilha ecológica
○ Artesanato
O Outro:

7) O empreendimento de Turismo Rural contempla algum recurso-atrativo histórico-culturalnatural? Múltipla escolha

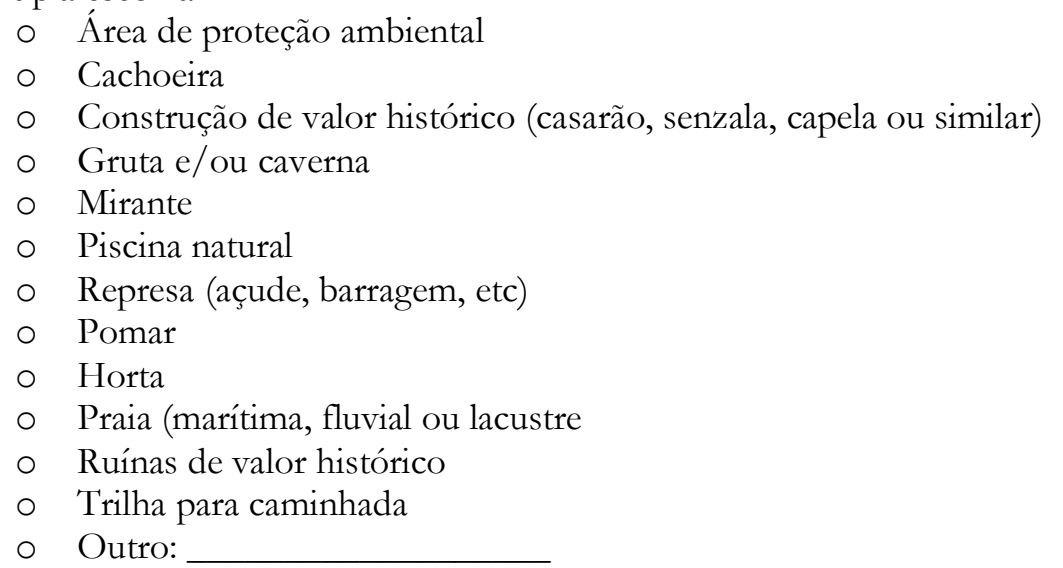

8) Há quantos anos o empreendimento desenvolve atividades de turismo rural?
- 1 mês -1 ano
- 1 ano e 1 mês -2 anos
- 2 anos e 1 mês -3 anos
- 3 anos e 1 mês -5 anos
- 5 anos e 1 mês -8 anos 
- 8 anos e 1 mês - 10 anos

- Mais de 10 anos e 1 mês

o Outro:

9) Anteriormente o empreendimento desenvolvia atividades e práticas agrícolas?

○ $\operatorname{Sim}$

○ Não

10) Atualmente o empreendimento desenvolve...

- Somente atividades de Turismo Rural

- Compartilha atividades de Turismo Rural e agrícolas

- Deixou de realizar atividades agrícolas quando iniciou as atividades de Turismo Rural

11) O empreendimento atende os visitantes e turistas...
- Sábados, Domingos e Feriados
- Somente aos Domingos
- Segunda à Sexta
- Todos os dias da semana
- Outro:

12) Os visitantes e turistas de seu empreendimento são oriundos de quais cidades principalmente...

Múltipla escolha - favor escolher as mais representativas
- São Paulo
- Grande SP (exceto ABC)
- $\mathrm{ABC}$
- Campinas
- Sorocaba
- Santos
- São José dos Campos
○ Ribeirão Preto
- Outro:

13) Como realiza a divulgação do empreendimento de Turismo Rural Múltipla escolha
- Site próprio
- Site do roteiro ou circuito que participa
- Facebook
○ Twiter
- Folheto
- Divulgação em rádio
- Divulgação em revistas
- Cartão de visita
- Divulgação em jornal
- Boca a boca
o Outro:

14) Qual o dia de maior movimento no empreendimento de Turismo Rural
- Domingo
- Sábado
- Feirado
○ Não consigo estimar

15) Qual o número de visitantes e turistas que o empreendimento estima receber por semana?

- $1-50$ turistas/visitantes por semana

- 51 - 100 turistas/visitantes por semana

- $101-300$ turistas/visitantes por semana

- $301-500$ turistas/visitantes por semana

- $501-1000$ turistas/visitantes por semana

- $1001-5000$ turistas/visitantes por semana

- Mais de 5000 turistas/visitantes por semana

o Outro: 
As perguntas a seguir são referentes a um cadastro unificado dos empreendimentos do Turismo Rural do Estado de São Paulo, essa base de dados servirá para realização de diagnóstico junto aos órgãos competentes e fortalecer a necessidade de aprovação junto ao Congresso Nacional da Lei de Turismo Rural.

16) A nova lei de Turismo Rural que tramita no Congresso Nacional visa regulamentar a atividade. Seu empreendimento atualmente se encontra registrado junto aos órgãos municipal, estadual ou federal?

$$
\begin{array}{ll}
\text { ○ Sim } \\
\circ & \text { Não } \\
\circ & \text { Outro: }
\end{array}
$$

17) Razão Social do empreendimento

18) $\mathrm{CNPJ}$

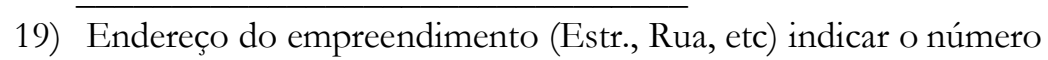

20) Bairro do empreendimento

21) CEP

22) Tem registro de produtor rural

o Sim

○ Não

23) Site do empreendimento

24) Facebook do empreendimento

25) Site e Facebook do Circuito ou Roteiro que está associado

26) Email de contato

27) Telefone fixo para contato

Favor informar o DDD

28) Telefone celular para contato

Favor informar o DDD

29) Quantos KM está distante do centro da cidade?
- Até $1 \mathrm{~km}$
○ De 1,1 a $5 \mathrm{~km}$
- De 5,1 a $10 \mathrm{~km}$
- Mais de $10 \mathrm{~km}$
○ Outro:

30) O acesso ao empreendimento é por estrada asfaltada ou de terra?
- Totalmente asfaltada
- Totalmente estrada de terra
- Parte asfaltada e parte de terra
- Outro:

31) O empreendimento tem apoio ou suporte de familiares para desenvolver as atividades
○ Sim
○ Não
O Outro:

32) As pessoas que desenvolvem atividades no empreendimento são...
○ Contratados 
○ Eventuais

- Contratados e Eventuais

- Familiares

- Contratados, Eventuais e Familiares

- Eventuais e Familiares

o Outro:

33) Quantas pessoas trabalham nas atividades do empreendimento...

- Apenas 1

- 2 a 5 pessoas

- 6 a 10 pessoas

- 11 a 20 pessoas

- Mais de 21 pessoas

o Outro:

34) Nome do responsável pelo preenchimento do questionário

35) Qual seu cargo no empreendimento

○ Proprietário

- Gerente

- Sócio-Presidente

o Outro:

36) A ABRATURR - Associação Brasileira de Turismo Rural-São Paulo, está desenvolvendo site, facebook, folhetos e outras ferramentas de promoção do Turismo Rural Paulista. Seu empreendimento teria interesse em aderir a essa proposta de divulgação unificada

○ Sim

- Não

- Outro:

37) Atualmente o Conselho Estadual de Turismo do Estado de São Paulo conta com a Câmara Temática de Turismo Rural e conta com um grupo no Facebook como forma de se divulgar e também estar informado do que acontece na área. O empreendimento teria interesse em participar desse grupo do facebook?

o Sim

○ Não

- Outro:

38) Alguma informação adicional que gostaria de estar sugerindo 


\section{ANEXO B}

Tabela - Empreendimentos de turismo rural por municípios

ABRATURR - 2014

\section{Empreendimento por munícipios segundo a Regiăo Administrativa (RA) (1)}

\begin{tabular}{|c|c|c|c|}
\hline RA & Cidades & $\begin{array}{l}\text { Frequência } \\
\text { Absoluta }\end{array}$ & $\%$ \\
\hline RA Barretos & Olímpia & 4 & 2,02 \\
\hline \multirow{10}{*}{ RA Bauru } & Agudos & 1 & 0,51 \\
\hline & Arandu & 1 & 0,51 \\
\hline & Arealva & 1 & 0,51 \\
\hline & Bauru & 1 & 0,51 \\
\hline & Botucatu & 1 & 0,51 \\
\hline & Dois Corregos & 1 & 0,51 \\
\hline & Jaú & 1 & 0,51 \\
\hline & Pardinho & 1 & 0,51 \\
\hline & Pederneiras & 1 & 0,51 \\
\hline & Sabino & 1 & 0,51 \\
\hline \multirow{17}{*}{ RA Campinas } & Atibaia & 1 & 0,51 \\
\hline & Caconde & 2 & 1,01 \\
\hline & Campinas & 4 & 2,02 \\
\hline & Holambra & 1 & 0,51 \\
\hline & Itatiba & 7 & 3,54 \\
\hline & Jaguariúna & 1 & 0,51 \\
\hline & Joanópolis & 7 & 3,54 \\
\hline & Jundiai & 1 & 0,51 \\
\hline & Jundiaí & 3 & 1,52 \\
\hline & Limeira & 3 & 1,52 \\
\hline & Louveira & 12 & 6,06 \\
\hline & Mococa & 2 & 1,01 \\
\hline & Morungaba & 1 & 0,51 \\
\hline & São João da Boa Vista & 11 & 5,56 \\
\hline & São Sebastião da Grama & 1 & 0,51 \\
\hline & Socorro & 2 & 1,01 \\
\hline & Vinhedo & 4 & 2,02 \\
\hline \multirow{6}{*}{$\begin{array}{l}\text { RA Central (Araraquara } \\
\text { e Säo Carlos) }\end{array}$} & Bocaina & 1 & 0,51 \\
\hline & Borborema & 1 & 0,51 \\
\hline & Brotas & 4 & 2,02 \\
\hline & Brotas & 1 & 0,51 \\
\hline & Caconde & 1 & 0,51 \\
\hline & Tabatinga & 1 & 0,51 \\
\hline \multirow{3}{*}{ RA Franca } & Cristais Paulista & 1 & 0,51 \\
\hline & Patrocinio Paulista & 1 & 0,51 \\
\hline & Pedregulho & 2 & 1,01 \\
\hline \multirow{9}{*}{$\begin{array}{l}\text { RA Metropolitana de São } \\
\text { Paulo }\end{array}$} & Atibaia & 2 & 1,01 \\
\hline & Guararema & 3 & 1,52 \\
\hline & Itupeva & 1 & 0,51 \\
\hline & Jundiai & 1 & 0,51 \\
\hline & Mogi das Cruzes & 12 & 6,06 \\
\hline & Ribeirão Pires & 1 & 0,51 \\
\hline & Salesópolis & 2 & 1,01 \\
\hline & Santa Isabel & 1 & 0,51 \\
\hline & Vinhedo & 2 & 1,01 \\
\hline
\end{tabular}


Empreendimento por munícipios segundo a Regiăo Administrativa (RA) (2)

\begin{tabular}{|c|c|c|c|}
\hline RA & Cidades & $\begin{array}{l}\text { Frequência } \\
\text { Absoluta }\end{array}$ & $\%$ \\
\hline \multirow{3}{*}{ RA Presidente Prudente } & lepê & 1 & 0,51 \\
\hline & Pirapozinho & 1 & 0,51 \\
\hline & Rosana & 1 & 0,51 \\
\hline RA Registro & Barra do Turvo & 1 & 0,51 \\
\hline \multirow{3}{*}{ RA Ribeirão Preto } & Altinópolis & 1 & 0,51 \\
\hline & Barrinha & 1 & 0,51 \\
\hline & Mococa & 1 & 0,51 \\
\hline RA Santos & Miracatu & 1 & 0,51 \\
\hline RA Santos, São José & Ubatuba & 1 & 0,51 \\
\hline \multirow{5}{*}{$\begin{array}{l}\text { RA São José do Rio } \\
\text { Preto }\end{array}$} & Cardoso & 1 & 0,51 \\
\hline & Monte Aprazivel & 1 & 0,51 \\
\hline & Santa Fé do Sul & 1 & 0,51 \\
\hline & Tabapuã & 1 & 0,51 \\
\hline & Uchoa & 1 & 0,51 \\
\hline \multirow{15}{*}{$\begin{array}{l}\text { RA São José dos } \\
\text { Campos }\end{array}$} & Bananal & 1 & 0,51 \\
\hline & Caçapava & 1 & 0,51 \\
\hline & Cachoeira Paulista & 2 & 1,01 \\
\hline & Guararema & 1 & 0.51 \\
\hline & Guararema & 1 & 0,51 \\
\hline & Joanopolis & 1 & 0,51 \\
\hline & Monteiro Lobato & 4 & 2.02 \\
\hline & Pindamonhangaba & 4 & 2,02 \\
\hline & Queluz & 2 & 1,01 \\
\hline & Salesópolis & 1 & 0,51 \\
\hline & Santo Antonio do Pinhal & 1 & 0,51 \\
\hline & São Bento do Sapucaí & 13 & 6,57 \\
\hline & São Jose do Barreiro & 1 & 0,51 \\
\hline & São José do Barreiro & 2 & 1,01 \\
\hline & Taubaté & 3 & 1,52 \\
\hline \multirow{9}{*}{ RA Sorocaba } & Alumínio & 1 & 0,51 \\
\hline & Ibiúna & 7 & 3,54 \\
\hline & Itu & 2 & 1,01 \\
\hline & Pardinho & 1 & 0,51 \\
\hline & Piedade & 6 & 3,03 \\
\hline & Piedade & 2 & 1,01 \\
\hline & Porto Feliz & 1 & 0,51 \\
\hline & São Roque & 11 & 5,56 \\
\hline & Total & 198 & 100,0 \\
\hline
\end{tabular}

